\title{
COMMENT
}

\section{A Penny for Their Thoughts: Employee-Inventors, Preinvention Assignment Agreements, Property, and Personhood}

\author{
Steven Cherensky
}

TABLE OF CONTENTS

I. Introduction

II. The Limitations of Doctrine: The Employee-Inventor and Preinvention Assignment Agreements Under Patent and Contract Law ................................. 602

A. Patents: Inventorship and Ownership ............. 602

B. Inventorship Paradigms and Metaphors: From "HeroInventor" to "Team-as-Hero" and Beyond............ 605

C. The Legal Status of Employee-Inventors............ 616 1. The Common Law ........................ 616

2. Preinvention Assignment Agreements........... 617

D. Legislative Responses to Preinvention Assignment Agreements .............................. 625

III. The Limitations of Theory: The Employee-Inventor and Preinvention Assignment Agreements Under Traditional Theories of Property ........................... 627

A. The Distinctive Nature of Intellectual Property ....... 627

B. Traditional Property Theories .................... 629

1. Natural Law Justifications.................... 629

a. First Occupancy Justifications .............. 632

b. Normative Labor Justifications .............. 633

2. Utilitarian (or Instrumental) Labor Justifications .... 635

3. The Failure of Traditional Theories.............. 641

IV. Personhood and the Employee-Inventor: An Alternative Framework for the Resolution of Preinvention Assignment Disputes ...................................... 641

A. Personhood Theories of Property ................. 642

1. Hegelian Personhood......................... 643 
2. Radinian Personhood ....................... 644

3. Personhood and Inventorship................. 646

B. Non-Personal Inventions: Corporate Inventorship as a

Consequence of Personhood Theory .............. 653

C. Personal Preinventions: The Employee-Inventor and the Personhood Defense ......................... 657

1. A Non-Appropriability Approach .............. 658

2. A Cancelhing or Balancing Approach ............ 659

3. A Disaggregation Approach .................. 660

a. The Fungible/Personal Dichotomy ........... 660

b. The Personhood or Inventor's Defense ........ 662

c. Some Apphications of the Personhood Defense and Comparisons to Current Doctrines .........663 663

i. Private Personal Use................... 663

in. As Compared to the Experimental Use Doctrine........................... 664

iin. Personal or Professional Commercial Exploitation ......................... 664

iv. As Compared to the Assignor Estoppel

Doctrine .............................. 665

V. Conclusion $\ldots \ldots \ldots \ldots \ldots \ldots \ldots \ldots \ldots \ldots \ldots \ldots \ldots, 666$ 


\title{
A Penny for Their Thoughts: Employee-Inventors, Preinvention Assignment Agreements, Property, and Personhood
}

\author{
Steven Cherensky†
}

Most technologists at American corporations work under preinvention assignment agreements whereby the employee-inventor promises to assign to the employer all interests in future patentable inventions that arise from the employment relationship. These agreements are typically upheld by courts. This Comment suggests that employee-inventors should retain greater property interests in their inventions. The author argues that the rubrics under which preinvention assignment agreements have been analyzed in the past-patent and contract doctrine and traditional property theories-fail to address the complex employee-employer and inventor-invention relationships implicit in organized invention. As an alternative framework for resolving preinvention assignment conflicts, the author proposes the application of personhood theory, particularly the market-inalienability concept forwarded by Margaret Radin. This approach suggests that an employee-inventor's relationship with her work can be justifiably constitutive of her personhood and that preinvention assignment agreements can interfere with this relationship. The Comment discusses specific proposals that preserve the personhood interests of employee-inventors without unduly impairing the economic interests of employer-corporations.

I

\section{INTRODUCTION}

If a man write a better book, preach a better sermon, or make a better mousetrap than his neighbour, though he build his house in the woods, the world will make a beaten path to his door.

-Ralph Waldo Emerson ${ }^{1}$

$\dagger$ B.S. 1980, The Johns Hopkins University; M.S. 1982, University of Michigan, Ann Arbor; J.D. candidate 1993, Boalt Hall School of Law, University of California, Berkeley.

I would like to thank Professor Rachel Moran for her assistance and encouragement. This Comment benefited greatly from her generosity, insight, and energy. Thanks also to Professor Peter Menell for his significant contributions to earlier drafts. Special thanks to Jodie Carter, Tom Freedman, Gary Gold, my editors Stephanie Siegel, Ann Kim, and Jeff Rake, and my friends and colleagues on the California Law Review. Finally, I wish to thank my parents, Carl and Gilda Cherensky, for their love and support.

1. Ralph W. Emerson, lecture, quoted in THE Penguin Dictionary of QuOTations 155 (J.M. Cohen \& M.J. Cohen eds., 1977). 
The world is probably beating down the wrong path in search of the better mousetrap. For today, that mousetrap was likely invented not in a house in the woods, but rather in a corporate research and development facility. And it is also likely that the employee who invented that better mousetrap agreed, before it was even invented, to assign her entire interest in the invention to her einployer. Such an agreement is known as a preinvention assignment agreeinent. $^{2}$

This Comment focuses on what are referred to here as "preinventions." Preinventions are inventions ${ }^{3}$ that have not yet been (and may never be) conceived at the time the parties agree to assign potential future patent rights. Whereas inventions are tangible, identifiable things, preinventions are intangible expectancies. Although much of what is said here will apply to inventions as well as preinventions, the goal of this Comment is to better understand and help to resolve the conflicting interests of einployee-inventors ${ }^{4}$ and their einployers in preinvention assignment agreenents.

Preinvention assignment agreeinents have presented "ancient but eternal"s probleins of contract and patent law for courts and coininentators. These probleins are different from those raised by assignment agreements for existing inventions. While assigninent of rights in existing inventions coinmodify and alienate the tangible invention, assignment of rights in preinventions coinmodify and alienate the inventive process. Consequently, parties who bargain for interests in existing inventions know or should know exactly what they are getting and giving up. Parties who bargain for preinventions have no such knowledge.

Both einployee-inventors and their einployers have strong proprietary interests in the inventions that result from the einployinent relationship. The einployee-inventors' interest inay be based on their investment of personal capital: training and education, personality, individual genius, extraordinary effort, creative spark, and even divine revelation. The einployers' interest, in contrast, inay be based on the financial capital invested in creating a work environment conducive, if not essential, to invention: plant and equipinent, einployee salaries, manageinent and oversight, and opportunities for collegial exchange.

For much of this century, courts, coinmentators, and legislators

2. A preinvention assignment agreement is a clause of an employment contract that obligates the employee to assign to the employer all interests in any future inventions conceived during (and in some cases, before and after) the employment term.

3. Unless otherwise stated, "invention" is used in this Comment as shorthand for patentable invention or discovery.

4. The phrase "employee-inventors" is used in this Comment to indicate that the individual is employed (by another individual, a corporation, a government, or others), not to indicate the type of employment (that is, employed as an inventor).

5. 6 Donald S. Chisum, Patents: A Treatise on the Law of Patentability, VALIDITY, AND INFRINGEMENT $§ 22.03$, at 22-8.1 (1992). 
have tried to balance the proprietary interests of einployee-inventors and their enployers in preinvention rights. ${ }^{6}$ The courts have developed a comprehensive set of common law rules to allocate preinvention rights; however, the pervasiveness of private agreeinents allocatimg these rights between employee-inventors and their employers has made these rules all but irrelevant. Today, virtually all technical employees agree, as a condition of employinent, to assign to the employer all rights to inventions conceived by the employee while at work, or in subject inatters related to work, or while using any resources of the employer. ${ }^{7}$ These premvention assignment agreements are generally upheld by courts. ${ }^{8}$

Courts inay be enforcing preinvention assignment agreements in part because they feel such agreements fill a gap in patent law. In its current state, patent law (or, inore accurately, instruinental arguinents about granting property rights in order to encourage invention) cannot provide a normative solution to preinvention assignment disputes. The business and nature of invention have changed drainatically simce the first Patent Act was enacted in 1790, but Congress and the courts have not adequately adapted the ineaning of invention to reflect these changes. Today's Patent Code $^{9}$ retains the eighteenth-century paradigm of the sol-

6. For examples of judicial decisions concerning the allocation of rights between employeeinventors and employers, see infra notes 93-124 and accompanying text. A partial list of commentary on the subject includes Robert L. Gullette, Fact or Fiction: Legislative Control of Employer-Employee Ownership Rights in Inventions and Other Intellectual Property, 1985 PaT. L. AnN. 7-1; Christopher M. Mislow, Necessity May Be the Mother of Invention, but Who Gets Custody? The Ownership of Intellectual Property Created by an Employed Inventor, 1 COMPUTER \& High-TeCH. L.J. 59 (1985); Arthur Nobile, Experiences with Industrial Patent Policy, in PateNT Policy: Government, ACADEMIC, AND INDUSTRY ConCEPTS 156 (Willard Marcy ed., 1978) [hereinafter Patent Policy]; John P. Sutton, The Inventor's Interest, in PATENT Policy, supra, at 150; Paul C. Van Slyke \& Mark M. Friedman, Employer's Rights to Inventions and Patents of Its Officers, Directors and Employees, 18 AM. INTELL. Prop. L. Ass'N Q.J. 127 (1990); Richard C. Witte \& Eric W. Guttag, Employee Inventions, 71 J. PAT. \& TRADEMARK OFF. Soc'Y 467 (1989); Arvid V. Zuber, Impact of Patent Policies on Creativity in Industrial Research Laboratories, in Patent Policy, supra, at 145; Jay Dratler, Jr., Note, Incentives for People: The Forgotten Purpose of the Patent System, 16 Harv. J. ON Legis. 129 (1979); Lucy Gamon, Note, Patent Law in the Context of Corporate Research, 8 J. CoRP. L. 497 (1983); William P. Hovell, Note, Patent Ownership: An Employer's Rights to His Employee's Invention, 58 NOTRE DAME L. Rev. 863 (1983); Henrik D. Parker, Note, Reform for Rights of Employed Inventors, 57 S. CAL. L. REv. 603 (1984); Thomas C. Siekman, Comment, Employer's and Employee's Rights in Patents Arising from the Employment, 11 VILL. L. REV. 823 (1966). For a discussion of legislative treatment of this arca, see infra Section II.D.

7. The employee typically receives a token payment in exchange for the assignment. Some firms may make more than a token payment, however, perhaps even a percentage of the value of the invention or of the royalties accruing from the invention. It will generally be assumed here that any consideration reccived by the employee in return for her promise to assign future inventions to her employer is either nominal or substantially less than the value of the inventions. Thus, the arguments put forward here are independent of consideration. For a discussion of consideration in the context of preinvention assignment agreements, see infra notes 124-30 and accompanying text.

8. See infra notes 106-07 and accompanying text. Some states do impose statutory limits on the scope of such agreements, however. See infra notes note 136-37 and accompanying text.

9. 35 U.S.C. $\S \S 1-376$ (1988 \& Supp. II 1990). 
itary, heroic mventor and fails to take imto account the modern paradigm of the team as imventor. Thus, existing patent laws justify granting property rights to the imventor-entity, ${ }^{10}$ but they do not help im determining whether the employee-inventor or employer should be entitled to such rights.

Similarly, courts may enforce premvention assignment agreements in order to avoid difficult contract issues such as adhesion and unconscionability, adequacy of consideration, freedom of contract, and structural difficulties implicit im ex ante bargaining for speculative rights. For example, employers almost umversally offer preinvention assignment agreements on a take-it-or-leave-it basis. Given the einployer's advantages im bargaining power, ${ }^{11}$ these preinvention assignment agreements raise thorny questions of contract law. By grantimg blanket enforcement of such agreements, courts avoid these questions, thereby obscuring and devaluing the contributions of mdividuals.

A word on the methodological organization of this Comment is appropriate here before the substantive organization is discussed. The use of premvention assignment agreements to appropriate the future inventions of employee-inventors presents courts with a difficult problemdifficult not in the sense of determining what the positive law is, ${ }^{12}$ but rather in reconciling patent and contract doctrine with the complex relationships between, and contributions of, employee-inventors and their employers. ${ }^{13}$ After establishing the limitations of doctrine, this Comment will proceed to apply traditional theories of property law to the problem. Like doctrime, however, traditional theory is not up to the task of resolving preinvention assignment disputes. Thus, an alternative theoretical approach-personhood theory-will be investigated as a potentially powerful tool for analyzing preinvention assignment disputes.

The approach taken here differs from many prior studies of preinvention assignment agreements by focusing on the underlying theoretical property issues rather than on issues of patent or contract law. General property law theory, however, is itself not without problems in analyzing preinvention assigninent disputes. Most theories of property law suffer from the same deficiencies as does patent law when applied to rights in preinventions; that is, most traditional justifications of private property focus on the rights of claimholders as against society and do not

10. The phrase "inventor-entity" is used in this Comment to refer to the combination of employee-inventor and employer.

11. The very nature of bargaining for nonexistent inventions tends to favor the employer. See infra note 126 and accompanying text.

12. The positive law of preinvention assignment agreements is fairly well settled; such agreements are valid and enforceable. See infra note 106 and accompanying text.

13. This is how Judge Harry Edwards defines a "hard" case. See Harry T. Edwards, The Growing Disjunction Between Legal Education and the Legal Profession, 91 MiCH. L. REV. 34, 44 (1992). 
resolve disputes between arguably legitimate claimholders. The focus here will be on examining claims to property interests inade by employeeinventors and employers. It will be argued that each has significant, cognizable proprietary interests in preinventions; that these interests are different interests based on different property justifications; and that the property rights in preinventions should be disaggregated and allocated between einployee-inventor and einployer according to the interests of each.

This Comment concentrates on inventorship and the allocation of property rights in patentable inventions in the corporate workplace. ${ }^{14}$ Although the discussion is largely relevant to invention in other organizational environments, such as university and government laboratories, and to other forms of nmovation and intellectual property, such as copyrights and mask works, the focus is not on these other areas. Where useful, distinctions from and coinparisons to these other areas will be made.

The substantive organization of the Comment follows the methodological organization outlined above. Part II discusses the linmitations of patent and contract doctrine as applied to preinvention assignment agreeinents. Because doctrine fails to deal adequately with the problenis posed by these agreeinents, Part III examines traditional property law theory as a potential dispositive source of legal authority. Traditional property justifications, it will be sliown, provide little guidance for resolving preinvention assignment disputes. Part IV presents an alternative property approacli for the resolution of preinvention assignment agreeinent disputes: personhood theory. Personhood theory suggests that certain rights of eniployee-inventors in their inventions be non-appropriable when those riglits are justifiably constitutive of the inventor's personhood.

This Comment explores two consequences of applying personhood theory to the problein of preinvention assignnient agreements. First, the employee-inventor should retain riglits in her invention only when she can demonstrate a justifiable personhood interest in the invention; otherwise, the employer should retain all interests in the invention, including credit as the inventor-entity. Thus, corporate inventorship is appropriate under certain conditions. Second, when the employee-inventor can deinonstrate a justifiable personhood interest in her invention, this personhood interest should be protected by reinoving the protected interest froin the inarket.

14. The employer will generally be assumed to be a corporation. At some points in this Comment, the corporate status of the employer is an explicit and important part of the discussion. For the most part, however, terms such as "employer," "corporation," and "firm" will be used interchangeably. 
II

The Limitations of Doctrine: The EMPloyee-

INVENTOR AND PREINVENTION ASSIGNMENT

AGREEMENTS UNDER PATENT AND

CONTRACT LAW

Most inventions today result froin the efforts of einployee-inventors. ${ }^{15}$ The Patent Code does not address the issue of inventions arising out of einployinent relationships, but the courts have devised a coininon law allocation of patent rights between einployee-inventor and einployer. Most corporations, however, perhaps uncoinfortable with the level of uncertainty that exists in the common law scheine, require their technical einployees (and often all einployees) to sign preinvention assignment agreeinents. This Part explores the legal context of these preinvention assigninents.

\section{A. Patents: Inventorship and Ownership}

The term "inventorship" defies precise definition. The Constitution grants Congress the power "[t]o proinote the Progress of Science and useful Arts, by securing for limited Times to Authors and Inventors the exclusive Right to their respective Writings and Discoveries,"16 but does not elaborate on what is ineant by "inventors" or "discoveries." Although the Supreine Court has often ruled on the ineaning of authorship, ${ }^{17}$ it has had hittle to say concerring the constitutional ineaning of inventorship. ${ }^{18}$

Patent law is no clearer on the subject. Under coininon law, inventorship refers to the process of conception and reduction to practice of a patentable invention. ${ }^{19}$ As William Bennett notes, an inventor is

15. By most estimates, $80 \%$ to $90 \%$ of all patentable inventions are the product of employceinventors. See, e.g., Ingersoll Rand Co. v. Ciavatta, 542 A.2d 879, 886 (N.J. 1988); A. Samucl Oddi, Beyond Obviousness: Invention Protection in the Twenty-First Century, 38 AM. U. L. REv. 1097, 1136 n.219 (1989); Parker, supra note 6, at 604.

16. U.S. CoNST. art. I, $\S 8$, cl. 8 .

17. See, e.g., Goldstein v. California, 412 U.S. 546, 561 (1973) (describing the constitutional meaning of "author" as " "originator,' "he to whom anything owes its origin" " and of "writings" as "any physical rendering of the fruits of creative intellectual or aesthetic labor") (quoting BurrowGiles Lithographic Co. v. Sarony, 111 U.S. 53, 58 (1884)); see also Feist Publications, 1nc. v. Rural Tel. Serv. Co., 111 S. Ct. 1282, 1288 (1991) (discussing the constitutional meanings of "author" and "writings"); Community for Creative Non-Violence v. Reid, 490 U.S. 730, 737 (1989) ("As a general rule, the author is the party who actually creates the work, that is, the person who translates an idea into a fixed, tangible expression entitled to copyright protection.").

18. See Donald S. Chisum, The Patentability of Algorithms, 47 U. P1TT. L. REv. 959, 1013 (1986) (noting paucity of Supreme Court rulings on meaning of inventorship).

19. See, e.g., Whitely v. Swayne, 74 U.S. (7 Wall.) 685,687 (1868) ("[H]e is the first inventor, and entitled to the patent, who, being an original discoverer, has first perfected and adapted the invention to actual use."). 
simply "the agency through which invention is effected."20 Although this definition is straightforward to apply $m$ the simple case of an individual, self-employed inventor, it becomes inurky in cases where the invention arises froin an employment relationship or where inultiple inventors are involved.

The Patent Code does little to amehorate these difficulties. Accordmg to the Code, the inventor of a "process, machine, manufacture, or composition of matter"21 may obtam a patent provided that the invention is "useful,"22 "novel,"23 and "non-obvious,"24 the subject matter is patentable, ${ }^{25}$ and the patentee coinplies with certain procedural requirements. ${ }^{26} \mathrm{~A}$ patent, once issued, grants the patent holder the right "to exclude others from making, using, or selling the imvention throughout the United States"27 for a period of years. ${ }^{28}$ The patent, however, does not grant the patent holder the riglit to exploit the imvention itself, ${ }^{29}$ as sucli right may be blocked by another patent. ${ }^{30}$

Although the Patent Code defines precisely what constitutes a patentable invention, it is not as precise in defining the term "imventor." One qualification is clearly required, lowever: only "natural" (tliat is, liuman) persons may qualify as inventors. Corporations and other nonnatural persons cannot be mventors under the Patent Code. ${ }^{31}$ Neither the legislative history nor commentators have articulated a clear justification for denying the fiction of the corporate person. ${ }^{32}$

20. William B. Bennett, The American Patent System: An Economic INTERPRETATION 27 (1943).

21. 35 U.S.C. § 101 (1988).

22. Id.

23. Id. \& 102 .

24. Id. \& 103.

25. See, e.g., Jay Dratler, JR., INTellectual Property LaW: Commercial, CREative, AND INDUSTRIAL PROPERTY § 2.02 (1991).

26. $I d$.

27. 35 U.S.C. $\$ 154$ (1988).

28. Fourteen years for a design patent, $i d . \S 173$, and 17 years for a utility or process patent, id. $\S 154$.

29. As will be discussed infra Section III.B, the right of an inventor to practice her own invention is based on common law rather than statute.

30. For example, inventor $A$ 's valid patent for a self-cleaning bathtub may be blocked by inventor $B$ 's basic bathtub patent.

31. See 35 U.S.C. $\& 115$ (1988) (requiring that the "applicant shall make oath that he believes himself to be the original and first inventor of the [invention] for which he solicits a patent," a requirement that no corporate person could fulfili); 6 CHISUM, supra note 5, § 22.01; Van Slyke \& Friedman, supra note 6, at 128 n.2; Dratler, supra note 6, at 141. Despite the common designation of the corporate entity as a "legal person," the rights accorded to corporations are limited in areas of the law beyond property. For example, a corporation is not a citizen, is not protected by the liberty provision of the Fourteenth Amendment, may not assert a right against self-incrimination, and is not protccted by the Privileges and Immunities Clause of the Constitution. See Note, Constitutional Rights of the Corporate Person, 91 YALE L.J. 1641, 1644 (1982).

32. This is especially surprising in light of the fact that patent law may be unique among forms of American intellectual property in this preclusion of "creatorship" by the corporate entity. The Copyright Code, for example, provides that the "employer or other person for whom [a] work was 
Establishing inventorship represents only the starting point for determining patent right ownership. Inventorship and patent ownership are distinct concepts under patent law. Inventorship is significant primarily for determining the patentability of claims and the procedural sufficiency of a patent apphication. ${ }^{33}$ Patent ownership, by contrast, carries with it the temporary, exclusive right to inake, use, or sell an invention. Thus, "inventorship" connotes a "power"-constituted ${ }^{34}$ relationship between individuals (inventors and non-inventors) with respect to inventions, whereas "patent ownership" connotes a "claim-right"constituted ${ }^{35}$ relationship between individuals (patent holders and nonpatent holders) with respect to patents.

There is no necessary legal relationship between inventor and patent holder for any given invention. Although the inventor is the presuinptive owner of property rights to patents issued for her invention, these rights are transferable by assignment. Patents have the attributes of personal property, ${ }^{36}$ and patents and patent applications may be assigned by written instrument. ${ }^{37}$ In fact, patents granted to inventors who have assigned their interest may be issued directly to the assignee, ${ }^{38}$ which may be any

prepared is considered the author" of such work. 17 U.S.C. $\S \S 101,201$ (b) (1988 \& Supp. III 1991). But the scope of copyright protection for corporate authors is not precisely the same in all respects as for human authors. For example, due to the theoretically infinite lifetime of corporations, copyright protection for works made for hire "endures for a term of seventy-five years from the year of its first publication, or a term of one hundred years from the ycar of its creation, whichever expires first" rather than the "life of the author and fifty years" duration of protection for works of human authorship. Id. $\$ 302(\mathrm{a})$, (c).

Similarly, the Semiconductor Chip Protection Act of 1984 [SCPA], a sui generis form of intellectual property protection for mask works fixed in semiconductor chip products provides authorship rights to financing entities. See id. $\$ \S 901(6), 902$. The "human inventor" requirement in the Patent Code may be explained by the higher threshold of originality and novelty needed for protection under this Code than under the Copyright Code or the SCPA. Note that while the Patent Code does not recognize corporate inventors, it does recognize that an invention may be the result of a collaborative effort among several humans. See 35 U.S.C. $\S 116$ (1988) (providing for joint inventorship). The question of corporate inventorship is explored further infra Section IV.B.

33. The procedural requirements of a patent application include the identification of the inventor and the performance of certain acts by the inventor. See, e.g., 35 U.S.C. $\$ 115$ (1988) (requiring the oath of the inventor); id. $\$ 111$ (requiring a written application).

34. "Power" is used in the Hohfeldian sense that the holder of a power can alter the legal position of either herself or another. In Hohfeldian terms, non-inventors have a "liability" with respect to inventions: they are susceptible to having their legal position altered. See WESLEY N. HoHFeld, Fundamental LEgal CONCEPTIONS AS APPLIED IN Judicial Reasoning 7, 50-60 (Walter W. Cook ed., 1923); see also STEPHEN R. MUNzER, A THEORY OF Property 18-19 (1990) (discussing Hohfeld's "power/liability" legal conception).

35. See James O. Grunebaum, Private Ownership 4 (1987) ("Ownership in general is a right constituted relationship, or set of relationships, between persons with respect to things."). Again, "right" is used in the Hohfeldian sense of entailing a duty in others, here the duty to refrain from making, using, or selling the subject matter of the patent for a period of 17 years after the patent issues. See HoHFELd, supra note 34, at 6-7, 36-38; see also MUNZER, supra note 34, at 18 (diseussing Hohfeld's "right/duty" correlative relationship).

36. 35 U.S.C. $§ 261$ (1988).

37. Id.

38. Id. $\S 152$. 
legal entity, including a corporation. ${ }^{39}$

\section{B. Invention Paradigms and Metaphors: From "Hero-Inventor" to "Team-as-Hero" 40 and Beyond}

The current Patent Code is based on the eighteenth-century view of invention-a view centered on a "hero-inventor" model. Eli Whitney, Alexander Graham Bell, and Tliomas Edison, for example, represent familiar images of "hero-mventors." 41 Today, "lero-inventors" are less coininon. ${ }^{42}$ Altliougl the disappearance of the "hero-imventor" may reflect, in part, changes in societal values, ${ }^{43}$ it reflects more significantly a slift from individual to team invention. The late-twentietli-century ana-

39. See Dorsey Harvester Revolving-Rake Co. v. Marsh, 7 F. Cas. 939, 942 (C.C.E.D. Pa. 1873) (No. 4,014) ("The right to acquire and hold patents is here clearly given to corporations (...").

40. The phrase is borrowed from Robert B. Reich, Entrepreneurship Reconsidered: The Team as Hero, HARV. Bus. REV., May-June 1987, at 77 (arguing that American industry inust strive for a model of collective entrepreneurship, as portrayed in Tracy Kidder's portrayal of the coinputer industry, The Soul of a New Machine, rather than the old model of "heroes and drones").

41. Interesting biographies of these hero-inventors include: ROBERT V. BRUCE, BELL: alexander Graham Bell and the Conquest of Solitude (1973); Constance McL.

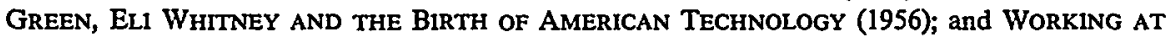
Inventing: Thomas A. Edison and the Menlo PARK EXPERIEnCE (William S. Pretzer ed., 1989) [hereinafter WoRKING AT INVENTING].

For a description of hero-inventors generally, see Roger BURLINGAME, INVENTORS BEHIND THE INVENTOR 3 (1947):

When you say the word inventor to most Americans, a lot of pictures junn suddenly into their ininds. They see Samuel Morse with his great white beard and his chest covered with medals standing by a telegraph key, ticking off the inessage "What Hath God Wrought." They see Robert Fulton watching his awkward little steamboat with great clouds of black sinoke pouring out of it, crawling up the Hudson. They see Eli Whitney grinding away at his cotton gin and they see Edison standing stiffly by a large incandescent bulb, considerably bored by the crowd of admirers round him. Some Americans even see Henry Ford watching his cars roll twenty seconds apart off his assembly line at River Rouge.

These are all pictures of popular Americans heroes. There is a regular parade of them before your mind's eye whenever anyone says the word inventor.

This "regular parade" of familiar inages does not accurately reflect the diversity of early American or, for that matter, contemporary American inventors. For a discussion of the contributions of women inventors, sec ANNE L. MACDONALD, FEMININE INGENUITY: WoMeN AND INVENTION IN AMERICA (1992). For a discussion of the contributions of African-Ainerican inventors, see Portia P. James, The Real McCoy: African-American Invention and INNOVATION, 1619-1930 (1989).

42. See BurLINGAME, supra note 41 , at 4 ("[T] he old-time inventor hero is no longer there when you go to look for him."); MACDONALD, supra note 41, at 333 (noting that during the course of the 20th century, "[womenl inventors had apparently ceased to be the heroines they once had been to their sisters."). There are well-known technologists, to be sure, but to a large extent the "hero-inventor" has been supplanted in popular folklore by the "hero-entrepreneur." Individuals such as Steven Jobs (Apple Coinputer and Next, Inc.), Bill Gates (Microsoft), and other well-known "technologists" are really famous for their business exploits rather than for any personal technological achievements. See, e.g., KeNNETh A. Brown, INVENTORS AT WorK 219 (1988). Brown notes, in an introduction his to interview with Steven Wozniak, designer of the Apple II personal computer, that "Wozmak was the thinker behind Apple Computer; Jobs was the driver. While Wozniak designed computers, Jobs set about marketing them." Id.

43. For example, technological "advances" are more often seen as a mixed blessing today than in the past. See, e.g., Samuel C. Florman, The Existential. Pleasures of Engineering 45 
logue to the "hero-inventor" is the "team-as-hero;" that is, invention resulting from the combined, coordinated efforts of a group rather than from the heroic efforts of an mdividual.

This Section will briefly describe some of the dominant characteristics of eighteenth- and twentieth-century invention and will discuss aspects of the modern inventive process relevant to preinvention assignment disputes. ${ }^{44}$ This Section will show that, while the "hero-inventor" paradigm maccurately explains contemporary invention by devaluing the contributions of teains, support staffs, and facilities, its widely accepted replacement-the "team-as-hero" model-inaccurately reflects contemporary invention by devaluing individual contributions.

The term "inventive process" is itself inappropriate to the extent that it imphes there exists some formula of how to invent. There is, of course, no such formula. Nevertheless, there are some coininon characteristics among the work environments in which much of today's invention takes place. A description of these common characteristics is what is referred to here as an "inventorship paradigm." 45 Certainly, inventorship paradigms will vary annong industries and technologies, among firm sizes, and even from inventor-entity to inventor-entity. In fact, as will be argued, the tendency of courts, legislators, corporations, and indeed, individual mventors to subscribe to a single (albeit different) inventorship paradigm lies at the root of preinvention assignment agreement conflicts.

The patent system, as originally conceived, was intended to encourage invention in a regime of individual inventors that differs markedly from today's workplace. "When this country's patent system was adopted ... . it was the independent, the 'lone' inventor who created new ideas through the exercise of his inventive faculties." ${ }^{\prime 46}$ Eighteenth-cen-

(1976) (describing the anti-technology movement of the 1960s and '70s that held "technology to be the root of all evil").

44. This Section relies in large part on JoHN JEWKES ET AL., THE SOURCES OF INVENTION (1958). Written in 1958 and revised and enlarged in 1969, this thoughtful essay remains a fruitful starting point for any study on the nature of invention and innovation.

45. The term "inventorship paradigm" here refers to the nature of the inventor-entity and has nothing to do with the subject matter, theory, technology, or techniques of the underlying invention. The term is used to refer to typical or representative descriptions of who or what invents, both individually and within organizations. Thus, inventorship paradigms describe inventor-entity orgamizational structures and interactions, or invention environments.

Inventorship paradigms are to be distinguished from scientific paradigms as that term is used by Thomas S. Kuhn in his influential essay, The Structure of Scientific Revolutions. Kuhn uses the term "scientific paradigm" to refer to an unprecedented achievement that establishes a school of scientific thought. Thus, Newtonian dynamics and Copernican astronomy arc examples of scientific paradigms. Thomas S. KuhN, THe STRUCTURE OF SCIENTIFIC ReVolutions 10 (2d ed. enlarged 1970).

Inventorship paradigms can be used both as an attempt to describe and catalog inventor-entities (and thus have the attributes of "model") and as a description of the public (or judicial or legislative) perception of inventor-entities (and thus have the attributes of "metaphor").

46. George E. Folk, Patents and Industrial Progress 144 (1942); see also Sutton, supra note 6, at 150 ("In 1790, when the first patent act was passed, there was no middle man 
tury invention was characterized by the individual efforts of non-professional, unspecialized, untrained inventors who worked primarily in their "house in the woods," as Emerson would say, ${ }^{47}$ or on their farms. ${ }^{48}$ These independent inventors had hittle need for capital beyond living expenses since they did not hire einployees and generally used readily available materials in their work.

Eli Whitney's invention of the cotton gin in inany ways typifies lateeighteenth-century invention. ${ }^{49}$ Whitney did not study to be an inventor; indeed, such an education would have been unavailable had he desired it. $^{50}$ While a guest at a South Carolina plantation, he heard neighboring planters discuss the difficulty of cleaning the local upland cotton of its seeds and the importance to the region of an inproved cleaning inachine. Whitney was persuaded to try his hand at a solution:

Whitney had never seen a cotton boll and had scarcely histened to the talk around him. But when his hostess proposed, albeit without undue urging, that he try to devise a machine, he pursued her suggestion ....

... A few days [later] he "involuntarily happened to be thinking on the subject and struck out a plan of a inachine ...."s1 That inachine, of course, was the cotton gin. Whitney built his first model froin wood, wire, and other materials that were readily available on the plantation..$^{52}$

Invention has changed dramatically in the 200 years since Whitney "struck out a plan" of his machine. Whitney's development of the cotton

between G[overnment] and I[nventors]. The inventor disclosed his invention in return for the right to exclude others for limited times.").

47. See supra text accompanying note 1 .

48. See E. Burke Inlow, The Patent Grant 37 (1950) (describing the 18th century in America as the "age of home industry").

49. For a detailed discussion of Eli Whitney and his invention of the cotton gin, see GrEEN, supra note 41.

50. In fact, Whitney studied at Yale with the eventual goal of practicing law:

In the late eighteenth century ... Yale was still primarily a training school for the pulpit, for the teacher's rostrun, for the bar and thence for posts of public responsibility. To attend college as preparation for an inventor's or manufacturer's career would have seemed a bizarre notion to the inen of the time. Whitney himself had no such thought.

Id. at 29.

51. Id. at 45-46. For a quite different account of the invention of the cotton gin, attributing significant inventive credit to Whitney's South Carolina hostess, Catherine Greene, see MACDONALD, supra note 41 , at xx-xxiv. Macdonald relates several versions of the invention, including the following:

[W] hen the cotton clogged the wooden teeth of Whitney's model, Greene remarked laughingly, "What! Allow such a trifle as that worry you? Trust to a woinan's wit to find the cure," seized the wire hearth-brush, and suggested to Whitney that he use it to comb through the cotton. Whitney gallantly replied, "Thank you for the hint. I think I have it now," and repaired to his workshop where he eventually developed the machine he patented-the one with wire teeth.

Id. at xxi. But see GREEN, supra note 41 , at 48 (discounting the contribution of Catherine Greene).

52. GREEN, supra note 41 , at 48 . 
gin is the inventorship paradigm envisioned by the drafters of the first Patent Act: the ad hoc problem-solving of the individual, generalist "hero-mventor." Organized invention was virtually unheard of at this time. ${ }^{53}$ Although the work of independent inventors remains important, ${ }^{54}$ most economically significant inventions today arise out of organizational environments. ${ }^{55}$ Thus, this Comment proceeds from the assumption that the inost important changes in inventorship paradigms over the last two centuries have been due to the appearance and growth of industrial laboratories and the professionalization of invention.

Nineteenth-century firms, were, by and large, passive consumers of technology rather than active participants in the inventive process. ${ }^{56}$ Inventors were not retained by firms as regular einployees to develop needed products or processes-indeed, firms inade little or no effort to direct independent inventors' efforts towards their specific needs. ${ }^{57}$

Most firms interested in acquirmg improvements adhered to this passive approach, because they considered imvention to be a product of imdividual mspiration, which could be guided in only the most general fashion. It was up to the inventors themselves to direct their efforts towards particular markets in the hope they might gain fame and fortune. ${ }^{58}$

Firms began to abandon this ad hoc approach to invention in the latenimeteenth century and sought to exert some control over invention through the establishment of industrial laboratories.

Early exainples of influential industrial laboratories include Thoinas Edison's "invention laboratory" estabhshed in Menlo Park, New Jersey, in $1876,{ }^{59}$ the Eastman Kodak Industrial Research Laboratory estab-

53. There were, for example, only seven joint-stock companies and corporations in existence in 1780. INLow, supra note 48 , at 37.

54. See, e.g., BRoWN, supra note 42 (containing interviews with several prolific independent inventors); Edmund L. Andrews, Rich in the 90's on Ideas Hatched in the 50's, N.Y. TimEs, Nov. 13, 1992, at Al (describing Jerome Lemelson, an independent inventor who has obtained nearly 500 patents); Carlos V. Greth, Technical Tinkerers, CHI. TRIB., Nov. 18, 1990, at C6 (describing the work of independent inventors); Robert Kanigel, One Man's Mousetraps, N.Y. TimEs, May 17, 1987, $\S 6$ (Magazine), at 48 (same).

55. This trend reflects the transformation of American society during the same period from individualist to organizational. See, e.g., MEIR DAN-CoHEN, RIgHtS, PERSONS, AND Organizations: A Legal Theory for Bureaucratic Society 13 (1986) ("In the early nineteenth century, four out of five Americans were self-employed; the number is now less than one in ten." Id. at 212 n.3) (quoting Charles Lindblom, Politics AND MARKets 28 (1977)); PAUL ISRAEL, From Machine SHOP to INDUSTRIAL LABORATORY: TELEgRAPHY AND THE Changing CONTEXT OF AMERICAN INVENTION, 1870-1920, at 151 (1992) (noting that changes in the post-Civil War telegraph industry "reflected a general transformation taking place in Ameriean society, as economic and political power began to shift from individuals to large-scale bureaucratic organizations").

56. See, e.g., ISRAEL, supra note 55, at 121-51.

57. Id.

58. Id. at 130 .

59. See, e.g., Thomas P. Hughes, Thomas Alva Edison and the Rise of Electricity, in 
lished in Rochester, New York, in 1912,60 and the laboratories at Bell Telephone and DuPont. ${ }^{61}$ There are many reasons for the rise of industrial laboratories at the beginning of the twentieth century, ${ }^{62}$ but perhaps the primary reason was the desire to improve efficiency and focus by bringing invention and innovation within the same firm. ${ }^{63}$

Innovation has been described as "the search for, and the discovery, developinent, improvement, and adoption of new processes, new products, and new organizational structures and procedures."64 Invention is a inuch narrower concept, encoinpassing inerely the "discovery" part of innovation. ${ }^{65}$ Innovation is an inherently risky and cumulative activity,

TECHNOLOGY IN AMERICA: A History OF INDividuals and IDEAS 117, 119 (Carroll W. Pursell, Jr. ed., 1990) [hereinafter Technology IN AMERICA]; David A. Hounshell, The Modernity of Menlo Park, in Worxing AT INVENTING, supra note 41, at 116 (characterizing Edison's laboratory as the model for 20th-century research and development facilities). Edison was a "hero-inventor" who fully understood the value of the "team-as-hero" and thus embodied both paradigms. See, e.g., Paul Israel, Telegraphy and Edison's Invention Factory, in WorKING AT INVENTING, supra note 41, at 66 . In many ways, Edison's story is

the story of a change in America; the story of how all work and effort from being separate, free, individual, disjointed, became organized and coordinated until finally, the team replaced the lone wolf in almost every department of hife and work including technological invention. Perhaps the most curious aspect of the whole story is Edison's part in this change. For, after his wandering career as one of the most rugged individuals in the history of invention, he became the pioneer of its colleetivization; the first American to apply teamwork to a pursuit which, above all others, was traditionally the property of lonely investigators living in garrets and carrying on their researches by the light of a candle shining dimly through cobwebs.

BuRlingame, supra note 41, at 178.

60. Reese V. Jenkins, George Eastman and the Coming of Industrial Research in America, in TECHNOLOGY IN AMERICA, supra note 59, at 129.

61. Id.

62. Some of the reasons include: the growth of monopolies and conglomerates which collected the capital and human resources necessary for the establishment of corporate laboratories, see, eg., Burlingame, supra note 41, at 193-94; William S. Pretzer, Introduction: The Meanings of the Two Menlo Parks, in Working AT INventing, supra note 41, at 12, 17 (noting that Edison received funding for the Menlo Park laboratory from Western Union, "one of the great American monopolies"); the great need for invention created by the growth of the country and the development of new technologies, see, eg., BURLINGAME, supra note 41, at 194-95; the parallel development of corporate and academic research in Europe, see, e.g., Israel, supra note 59, at 83; Jenkins, supra note 60, at 136-38; and the growing availability of academically trained scientists and engineers, see, e.g., Jenkins, supra note 60, at 141.

63. JEWKES ET AL., supra note 44 , at 182 . The combination of these functions within the firm was intended to further the following goals:

[F]irst, to gather together more of the resources incidental to research, to provide the research worker with the best aids, devices and working conditions; second, to encourage co-operation between different minds, and third, to try to give some guidance about the kind of inventions which would be most useful to the firm.

Id. at 132. As Jewkes points out, while the first goal is attainable in industrial laboratories, the latter two are far more elusive. Id. at 133-34. Perhaps more to the point, the latter two goals are rcally aimed at innovation rather than invention.

64. Thomas M. Jorde \& David J. Teece, Innovation, Cooperation and Antitrust, 4 HIGH TECH. L.J. 1, 5 (1989).

65. Not all discoveries are inventions, of course. For a definition of "invention," see supra notes 3, 21-26 and accompanying text. 
often turning up "dry holes" and "blind alleys," while requiring the inventor to "build[ ] on what went before."67 Moreover, innovation is complex, requires contributions from many disciplines, and can be very expensive.

Industrial laboratories are intended to address these aspects of innovation. According to one commentator, "Since innovation is so risky, so complex, and so expensive, companies strive to rationalize it-to build 'innovation factories.' That's the Holy Grail that launched Bell Labs, GE Labs, and the very idea of industrial research in America."68 These "imnovation factories" are designed to provide a fertile environment for invention and eliminate tle distractions faced by the independent inventor. ${ }^{69}$

A development that paralleled and helped to facilitate the rise of the mdustrial laboratory was tlie professionalization of invention. ${ }^{70}$ At about the time Edison established his "invention factory," science and invention became linked as never before. ${ }^{71}$ This linking of science and invention resulted in the development of the modern engineering disciplines and modern teclinical education. ${ }^{72}$ The formalization of the engineering

66. Jorde \& Teece, supra note 64 , at 5 .

67. Id. 42,43 .

68. Michael Schrage, Innovation and Applied Failure, HARv. Bus. REv., Nov.-Dec. 1989, at

69. These distractions include the provision of "atmosphere, background information, direction and resources in terms of space, heat, light, equipment, time, supporting services, salary and in many cases the identification of the problem to be solved." $\mathrm{H}$. Fredrick Hamann, Invention in the Corporate Environment, 1 AM. PAT. L. ANN. Q.J. 102, 106 (1972).

70. Edison himself was one of the first "professional inventors." See BuRLingamE, supra note 41 , at $190-91$.

71. It would be overly simplistic to characterize 18th-century invention as "empirical" (that is, somewhat accidental or not based on prior scientific knowledge) and 20th-century invention as "scientific." There is some truth, however, in Jewkes' characterization of "an earlier heroic age of clumsy individual pioneering and a modern age in which highly trained, closely organised teams of technologists, fortified by an easily accessible and constantly expanding body of scientific knowledge, move forward with deliberation to results which can largely be predetermined." JEWKES ET AL., supra note 44, at 32; see also Newton H. CopP \& ANDrEW W. ZANELlA, Discovery, INNOVATION, AND RISK 5-9 (1993) (contrasting the trial-and-error approach to technology taken in the 18th and early 19th centuries to the more systematic and scientific approach taken in the late 19 th and 20th centuries).

72. See, e.g., Copp \& ZANElla, supra note 71, at 5 (noting how the relationship between enginecring and the natural sciences has grown notably closer over the past 100 to 150 years); EdWin T. LAYTon, JR., The Revolt of the ENGINEERs: Social Responsibility and the AMERICAN ENGINEERING PROFESSION 38 (1986) ("The professionalization of engineering was everywhere associated with the shift from a craft to a scientific base for the underlying technology ...."); Bruce Sinclair, Thomas P. Jones and the Evolution of Technical Education, in TECHNOLOGY IN AMERICA, supra note 59, at 62-70 (describing the development of scientifieally oriented technical education in America). The difference between science and engineering has been expressed in the following terms: "Scientists seck general patterns in nature that can be summarized in models and theories. . . . Engineers have come to use much of the methodology of science, but the nature of the questions differ from science as engineers seek better machines, structures, systems, chemicals, or processes." CoPP \& ZANELlA, supra note 71, at 5 . 
disciplines, in turn, resulted in the professionalization of invention: And what has engineering done for the inventor? Through the developinent and application of scientific principles [engineering] has not only supplied necessary controls for design, construction, and operation, but [it] has in addition provided the great background of knowledge for use in further invention. In earher times the inventor was an individualist. Today he is inost likely to work in groups. The time has passed when it is easy for the lawyer or the doctor to coine forth with a fundamental invention. ${ }^{73}$

The professionalization of invention is, in soine respects, a self-perpetuating condition that has contributed both to the decline of the independent inventor and to the routinization of invention. ${ }^{74}$ Today, virtually all would-be inventors will complete soine mininuin standard of technical traiming. It is debatable whether scientific training is now required for invention or whether that is simply a perception entertained by firns. ${ }^{75}$ Whichever the case, at least an undergraduate degree in science or engineering is considered generally to be a prerequisite for inany types of inventive employinent. ${ }^{76}$ By requiring that technical einployees come from similar educational backgrounds, the professionalization of invention has served to limit the intellectual, ${ }^{77}$ gender, ${ }^{78}$ and racial diver-

73. S.C. Hollister, The Inventor's Contribution to Engineering Progress, in UNITED STATES Patent Law Sesquicentennial Celebration 5, 7 (U.S. Patent Office, Dep't of Commerce ed., 1941).

74. Routinized invention may have a certain attraction to firms seeking specific results or maintenance of the status quo. But routinized invention may not be in the best interests of society, which benefits most from revolutionary inventions. One commentator has described routinized invention thus:

Unfortunately, there is a trade-off [involved in industrial laboratories]... . [The] director of .. . a leading German chemical manufacturer, decided that [industrial] laboratories routinized invention. He characterized the inventions of industrial research laboratories as establishment or institutional inventions that had von Gedankenblitz keine Spur (no trace of a flash of genius).

Schrage, supra note 68 , at 43 (third alteration in original). In the terminology of Thomas Kuhn, industrial laboratories do not produce invention paradigms, but rather "normal invention" (that is, they work within established paradigms). See KUHN, supra note 45, at 10-34; see also FLOYD L. Vaughan, The United States Patent System: Legal and Economic Conflicts in AMERICAN PATENT History 276 (1956) ("In spite of, and partly because of, these alleged advantages [of industrial laboratories, the employed inventor] seldom brings forth a great invention, although he and his fellow-employees are very effective in developing and improving the inventions of others . ...").

75. It is also debatable whether technical training (or current levels of technical training) is even desirable as a means of fostering invention. See, e.g., Burlingame, supra note 41, at 182 (noting that the famous radio inventor Edward Howard Armstrong believed that too much scientific schooling may hinder an inventor).

76. There are, of course, exceptions to this rule. For example, some corporations with hierarchical technician (non-degreed) and engineer (degreed) job classifications occasionally permit exceptionally talented or experienced technicians to jump to the engineer classification.

77. For example, formally trained engineers tend to be theoretical inventors rather than experimental inventors. See, e.g., BuRLINGAME, supra note 41, at 180-83.

78. Professionalization has made it more difficult for those who do not meet the preconceived 
sity $^{79}$ of inventors.

The rise of the industrial laboratory and the professionalization of invention may have come at great financial and creative cost. Prospective inventors inust make a significant financial investment to attain the level of education required for today's inventive careers. This investment may cause individuals to becoine risk-averse, making the secure salaries of industrial laboratories even inore enticing. Furthermore, the standard training received at nost universities emphasizes tools and techniques that are beyond the financial ineans of most individuals. Thus, professionahisin can undermine entrepreneurship, which lies at the heart of the traditional concept of patent law. As one commentator has asked:

[S] imce invention has traditionally been so closely bound up with independence and since, even in this century, so many significant innovations have seen the hight of day [in industrial laboratories], it may be asked whether the growing importance of the industrial research laboratory is an uunixed blessing. To put it in terms of pohicy, is the trend one which should be consciously encouraged? Or is it one to which we should seek to set limits by trying to make easier the lot of the inventor who prefers to choose a path for himself? ${ }^{80}$

The developinent of institutional research and the professionalization of mvention reflected general societal trends toward specialization

corporate profile of "inventor" to obtain access to and positions of responsibility in research facilities. In 1957, for example, then-director of RCA Patent Operations, Clarence Tuska, an "adinittedly 'old-fashioned' man," pointed out that the "Lord intended [woinen] to be mothers rather than inventors." MACDONALD, supra note 41, at 334. Many lab directors today doubtless share Mr. Tuska's sentiments. For a discussion of the historical and continuing structural barriers faced by woinen in engineering and the physical sciences, see Shirley M. Tilghman, Science vs. the Female Scientist, N.Y. TIMEs, Jan. 25, 1993, at A11 (noting that women earn just seven percent of new engineering doctorates and that little progress has been made on this front in the last 50 years). See also Deborah L. Rhode, Perspectives on Professional Women, 40 STAN. L. REv. 1163 (1988) (discussing women in the professions generally, including engineering).

79. See, eg., JAMES, supra note 41 , at 15 :

As technology becaine inore complicated, inventors in emerging fields began to have more fornal education. Advanced degrees in engineering and the sciences were necessary to participate in these new technologies. Blacks found it difficult to get access to higher education and also found it difficult to obtain research staff positions.

See also id. at 95-96 (describing how African-American men and women have historically found it difficult to obtain the requisite degrees for corporate technical employment and to overcome the reluctance of corporations to employ them).

80. JEWKES ET AL., supra note 44, at 126 . The professionalization of invention may thus have brought about an ironic result: fewer people enter the profession, resulting in fewer inventors and hence, fewer inventions. Prospective inventors are all but required to invest human and financial capital in technical education, driving most to careers in industrial laboratories. But careers as corporate inventors have limited upside potential because the corporation has appropriated most of the upside. This limited potential in turn deters potential inventors from investing in technical education (or at least eliminates the incentive for investing in technical education which the patent system should in theory provide). Worse yet, those who have already invested in the education and have worked in the industrial laboratories may decide to lcave the profession because of the inability to realize significant gain on their inventions. 
and the division of labor, as connoted by the phrase "invention factory." It was believed that the econonies of mass production and division of labor that Adam Snrith docuinented in the production of pins $^{81}$ could be applied to the production of inventions. ${ }^{82}$ Inventions are not pins, lowever, and industrial laboratories are not necessarily efficient producers of inventions. ${ }^{83}$ Moreover, the specialization of labor encouraged, if not demanded, by institutional researcl can work to the disadvantage of individual einployee-inventors. While firms can spread technology risks by acquiring a diversified portfolio of technologically trained einployee-inventors, it is inpracticable for individual employee-inventors to acquire a diversified portfolio of technology- or firm-specific skills. ${ }^{84}$

Tlus, the "teain-as-hero" paradigm of invention lias both positive and negative inplications. The benefit of "teain-as-liero" inventing is that througli specialization and division of labor, inventions that niglit never have resulted from individual, independent, liaphazard efforts can be realized. A darker side is the personal cost to the individual inventor, as described above. There may be societal costs as well. Revolutionary inventions appear to occur less frequently in large institutional environinents. ${ }^{85}$ Perhaps this is due to the numbing effects of the professionalization of invention or to the exigencies of "rational" firm goal-setting. Another possibility, though, is that the orgamzational environments, coinplete with preinvention assignment agreenents that reinove individual incentives (and, as will be argued in Part IV, ahenate the inventor's personhood interests) constitute structural impediments to truly creative

81. Smith admiringly described the mass production of pins as follows:

One man draws out the wire, another straights it, a third cuts it, a fourth points it, a fifth grinds it at the top for receiving the head, to make the head requires two or three distinct operations; to put it on is a pecuhar busmess, to whiten the pins is another; it is even a trade by itself to put thein into the paper; and the important business of makiug a pin is, in this manner, divided into about eighteen distinct operations, which, in some manufactories, are all performed by distinct hands .... .

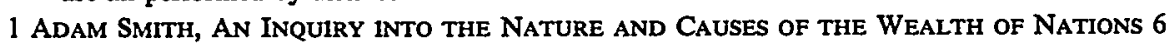
(James E.T. Rogers ed., 2d ed., Oxford, Clarendon Press 1880) (1776).

82. See JEWKES ET AL., supra note 44, at 238 ("The underlying principle, rarely formulated precisely but ever present, has been that originality can be organized . . . that inass production will produce originality just as it can produce sausages."). Jewkes relates the story of a corporate executive who, upon hearing an estimate that a certain piece of research would require six men for two years, instructed the director of research to put 12 men ou the job for one year. Id. at 137 n.1.

83. Id. at 132 (noting that "[ $\mathrm{t}]$ he industrial laboratory does not appear to be a favorable environment for inducing invention"); $i d$. at 185 (asserting that "[t]he large research organizations of industrial corporations have not been responsible in the past fifty years for the greater part of the siguifieant inventions").

84. See, e.g., Oliver E. Williamson, The Economic INSTitutions of Capitalism 258-59 (1985). Williamson downplays the importance of this effect, however, by noting that employees can choose between geueral purpose and firm-specific skills, and that highly skilled workers can usually obtain alternative employment, albeit at reduced productivity levels. Williamson fails to note that many firm- and technology-speeific skills are required as a condition of continued employment and that reduced compensation often accompanies the reduced productivity.

85. JEWKES ET AL, supra note 44, at 184-86. 
invention. These impediments reflect a larger cost associated with the popular perception of "team-as-hero" inventing: the societal devaluation of inventors and inventing. It is difficult for the general public, legislatures, and courts to appreciate the efforts of those inventors who may be perceived as "corporate tools" and inore difficult still to appreciate the efforts of individual ineinbers of corporate teams. ${ }^{86}$

The preceding pages inay paint a rather depressing picture of corporate drones inarching blindly but inethodically through corporate labora. tories squelching individual invention and creativity-"crowds of people milling around with an air of fictitious activity, behind a facade of massive inediocrity." 87 But this scenario is clearly not representative. While independent invention may be on the decline, individual invention is still thriving. Individuals invent, even in large organizations. ${ }^{88}$ In fact, much of what teanis do at industrial laboratories can be characterized more as innovation or developinent than invention; that is, corporate laboratories and teains "rationalize" innovation, not invention.

The act of invention is still described by many commentators as es. sentially an individual act, even within large corporate laboratories. ${ }^{89}$ Consider the comments of a CEO of a large corporation known for innovation:

The creative process usually starts with a brilliant idea . . . .

$\cdots$

... Innovation is an emotional experience. ... The desire to

innovate comes partly from the genes; you're born with it. It also

coines froin your early life, your education, the kind of encourage-

86. This might, in part, explain the general hostility of courts toward patents throughout much of the 20th century (that is, courts themselves may have devalued invention). See, e.g., Robert P. Merges, Commercial Success and Patent Standards: Economic Perspectives on Innovation, 76 Cal.1F. L. REV. 803, 821 n.65 (1988) (noting that the various federal circuit courts found two-thirds of patents adjudicated between 1921 and 1973 to be invalid). Some circuits (namely, the Second, Third, Eighth, and D.C. Circuits) were considerably worse. See Robert L. Risberg, Jr., Comment, Five Years Without Infringement Litigation Under the Semiconductor Chip Protection Act: Unmasking the Spectre of Chip Piracy in an Era of Diverse and Incompatible Process Technologies, 1990 WIS. L. REv. 241, 267 n.130. The Supreme Court has been notoriously hostile to patents, at one point prompting Justice Jackson to declare that "the only patent that is valid is one which this court has not been able to get its hands on." Jungersen v. Ostby \& Barton Co., 335 U.S. 560, 572 (1949) (Jackson, J., dissenting). The Court of Appeals for the Federal Circuit, formed in 1982 to have jurisdiction over patent appeals (among other duties), has been distinctly more "pro-patent" than its predecessor circuits and the Supreme Court. See Merges, supra, at 822 (noting that during its first four years, the Federal Circuit invalidated only $44 \%$ of the patents it adjudieated); Eric Schmitt, Judicial Shift in Patent Cases, N.Y. TIMES, Jan. 21, 1986, at D2 (noting the increasingly pro-patent sentiment of the Federal Circuit). But see Edmund L. Andrews, Rolling Back the Power of Inventors, N.Y. TIMES, Jan. 4, 1993, at C2 (noting a possible reversal of this trend).

87. JEwkes ET Al., supra note 44, at 162 n.1 (quoting S.C. Harland, Recent Progress in the Breeding of Cotton for Quality, J. TEXTILE INST., Conference Issue, Feb. 1955).

88. See FolK, supra note 46, at 166 ("The inventor, whether he be a lone worker or a group worker, is as important as he ever was.").

89. See, e.g., Mary H. Sears, The Corporate Patent: Reform or Retrogression, 22 VILL. L. REV. 1085, 1120-21 nn.158-59 (1977) and sources cited therein. 
ment you got to be creative and original. Innovative people come in all shapes and sizes and in all personality types. Some people are happiest when they're wrestling with a problem; I'm one of those. Others go into a green funk. They're miserable and depressed until they have the answer. But you can't have a good teclinologist who's not emotionally involved in the work. You can't have a good teclinologist who doesn't wake up in the middle of the might searching for answers. You can't have a good technologist who doesn't come into the lab eager to see the results of last night's experiment. ${ }^{90}$

The danger, then, of the "team-as-hero" paradigm is that it is applied overinclusively; that is, those outside the team (including courts) discount the contribution of imdividuals and focus solely on the team. The challenge faced by Patent Code revisers is thus to develop a concept of mventorship which recognizes both organizational and individual inventors.

This Section has discussed how the inventorship paradigm upon which the Patent Code was premised-"hero-as-inventor"-is, in many respects, not the inventorship paradigm under which invention proceeds today. Similarly, the inventorship paradigm that has largely supplanted the eighteenth-century paradigm-"teain-as-hero"-does not accurately describe much of today's invention. Neither paradigm nor, for that matter, the Patent Code or the courts recoginize the special probleins of the einployee-inventor.

Perhaps the problein is that "hero-inventor" and "team-as-hero" are inore inetaphor than paradigm. That is, "heroes" and "teams" are merely figures of speech that suggest the two poles of inventorship rather than inodels that accurately describe inventorship in any particular instance. If this is true, then it is important that the law not rely on one or the other as a rigid paradigm, but rather be flexible enough to encoinpass the spectruin of inventorship that exists between the poles.

Despite the problems with using the tern "inventorship paradigm," it continues to be useful when einployed as a shorthand ineans of expressing changing conceptions and meanings of inventorship. As used in this Comment, then, "inventorship paradigin" will have a very broad ineaning, encompassing both inodel and metaphor.

This Section has discussed some of the many changes that have occurred over the last 200 years in inventorship and in the public and legal perception of inventorship, and how patent law has remained relatively

90. Comments of Paul Cook, CEO of Raychem Corporation, in William Taylor, The Business of Innovation: An Interview with Paul Cook, HARv. Bus. Rev., Mar.-Apr. 1990, at 96, 98-99; see also Schrage, supra note 68, at 44 ("The most successful corporate innovation systems aren't 'systems' at all. They are environments hospitable to interesting people with innovative ideas."). 
static during this time. ${ }^{91}$ The next Section will document how the common law has played a "gap-filling" role ${ }^{92}$ by resolving employee-inventor disputes im light of the disjunction between changing inventorship paradigms and the relatively unclianging patent law. The next Section will also discuss how private agreements between employee-inventors and their employers liave largely supplanted the common law fornulation.

\section{The Legal Status of Employee-Inventors}

\section{The Common Law}

Absent an express agreement between the parties, courts use equitable common law principles to allocate property rights in inventions between employee-mventors and employers based on the nature of the employment relationship, the subject matter of the invention, and the resource contributions of the employer. The common law fornulation ${ }^{93}$ distinguishes among three types of employment: (1) specific inventive employment, which is employment for the express purpose of creating employer-specified inventions; (2) general mventive employment, which is typically referred to today as "researcl,", "desigu," or "development" employment; $; 4$ and (3) general employment. Specific inventions are the

91. But see infra 293-300 and accompanying text (discussing changes in the Patent Code and related case law).

92. See Melvin A. Eisenberg, The Nature of the Common Law 159-60 (1988) (discussing the court's role as gap-filler for the common law).

93. The common law allocation of property rights between employee and employer was developed over 90 years in a series of 19 th- and early 20th-century Supreme Court cases culminating in the landmark case of United States v. Dubilier Condenser Corp. See McClurg v. Kingsland, 42 U.S. (1 How.) 202 (1843) (holding that the employment relationship justified the presumption of a license from employee to employer); United States v. Burns, 79 U.S. (12 Wall.) 246 (1871) (holding that employers had a right to inventions of "specifically employed" inventors); Hapgood v. Hewitt, 119 U.S. 226 (1886) (holding that an employer's implicd license is personal and non-transferablc); Solomons v. United States, 137 U.S. 342 (1890) (discussing the "employed to invent" doctrine); McAleer v. United States, 150 U.S. 424 (1893) (finding an express agreement to assign); Gill v. United States, 160 U.S. 426 (1896) (holding that an implied license estopped an employee from bringing an action against her employer); Standard Parts Co. v. Peck, 264 U.S. 52 (1924) (establishing the implied shop-right of an employer); United States v. Dubilier Condenser Corp., 289 U.S. 178 (1933) (concluding that an employee not hired to invent is not obligated to assign a patent absent an express agreement). Many of the cases, including Dubilier, involved inventions of employees of the federal government. The common law concerning the allocation of rights to inventions of federal government employees have been modified by exeeutive order and by statute, thus largely superseding Dubilier on its specific facts. See, e.g., Exec. Order No. 10,096, 3 C.F.R. 292 (1949-1953), reprinted as amended in 35 U.S.C. $\$ 266$ (1938) (establishing basic policy with respect to domestic rights in inventions made by federal employees); 37 C.F.R. $\$ \$ 501.1-.10$ (1991) (regulations implementing Exec. Order 10,096); Heinemann v. United States, 796 F.2d 451 (Fed. Cir. 1986) (upholding Exec. Order 10,096), cert. denied, 490 U.S. 930 (1987); infra notc 142 (discussing 15 U.S.C. $\S \S 3710 c-3710 d$ (1988), which provides for mandatory compensation for inventors employed by the federal government). Nevertheless, Dubilier continues to state the general common law as to non-governmental employees.

94. Dubilier, 289 U.S. at 188 ("[E]mployment merely to design or to construct or to devise methods of manufacture is not the same as employment to invent."). 
property of the einployer. ${ }^{95}$ General inventions-which include inventions of specifically inventive employees that are not employer-specified, inventions of generally inventive einployees, and inventions of general employees-are the property of the employee-inventor, though einployers have a "shop-right" or non-exclusive right to practice the invention if it is developed on coinpany time or though the use of coinpany resources. ${ }^{96}$ Free inventions, which include all other inventions, are the exclusive property of einployee-inventors. ${ }^{97}$

Today, the operational significance of the common law allocation of property rights between einployee-inventor and employer is shight due to the prevalence of express preinvention assignment agreements, which are essentially private agreements not to abide by the common law or default allocation. Nevertheless, the common law rules are imstructive in that they provide an indication of norms, pohicies, and usages as understood by the courts over a period of time. ${ }^{98}$

\section{Preinvention Assignment Agreements}

The common law approach apphes equitable principles to the factual circumstances of individual cases. Most employers are unwilling to rely on the uncertainty ${ }^{99}$ and perceived equities ${ }^{100}$ of the common law. Thus, most employers make preinvention assignment agreements a condition of employinent. ${ }^{101}$ These agreeinents supersede the coininon law

95. Id. at 187.

96. Id. at 187-89. This shop-right extends for the duration of the patent term and does not expire with termination of the employment relationship. A derivative of the shop-right doctrine, the "reverse shop-right," is discussed infra note 333 and accompanying text.

97. Dubilier, 289 U.S. at $187-88$. Interestingly, this common law allocation appears to have been based on the existence of an implied premvention assignment agreement for inventive employees:

The reason [that an inventive employee is bound to assign his patents to the employer] is that he has only produced that which he was employed to invent. His invention is the precise subject of the contract of employment. A term of the [employment] agreement necessarily is that what he is paid to produce belongs to his paymaster. On the other hand, if the employment be general, albeit it cover a field of labor and effort in the performance of which the employee conceived the invention for which he obtained the patent, the [employment] contract is not so broadly construed as to require an assignment of the patent.

Id. at 187 (citations omitted).

98. See EISENBERG, supra note 92, at 14-42 (1988) (discussing ways in which social propositions figure into judicial reasoning).

99. For example, it can be difficult to distingnish specifically inventive from generally inventive employees on a legal basis. See, e.g., Mislow, supra note 6, at 63-67 and cases noted therein.

100. Implicit in the common law formulation is the behief that generally inventive employees should, as a matter of fairness, be entitled to patent rights in their inventions. Employers, however, undoubtedly view the common law formulation as inequitable.

101. In 1973, 84\% of U.S: patents went to corporate assignees. See Parker, supra note 6, at 604 n.12. Additionally, a study of California inventors issued chemical patents during the last quarter of 1973 indicated that $90 \%$ had signed preinvention assignment agreements. Id. at $604 \mathrm{n} .15$; see also Dratler, supra note 6, at 155 (stating that "nearly all of the . . . American scientists and engineers who work in industry have executed some sort of assignment agrecment"). 
allocation rules.

This Comment argues that, based on property law principles, preinvention assignment agreeinents should not be enforced in their entirety. Such agreements appropriate from the einployee-inventor that which should be malienable. ${ }^{102}$ This property analysis inakes the contractual analysis to some extent irrelevant. ${ }^{103}$ However, because the solution proposed by this Comment will leave much of the attempted premvention transfer intact, and because courts rely so heavily upon a contractual analysis in resolving preinvention assignment disputes, this Section will address some of the sahent points of preinvention assignment agreements qua contracts. Contrary to the position generally taken by the courts, this Section will argue that these agreenents are problematic under a contract law analysis.

The scope of most preinvention assignment agreeinents is broad. ${ }^{104}$ Some agreeinents require employee-imventors to assigu all inventions

102. The inalienable interest and the extent to which preinvention assignment agreements ought not to be enforced will be discussed infra Part IV.

103. For example, we would not analyze whether the terms of a contract for the inter vivos transfer of a vital bodily organ were enforceable on contract grounds. The property concept prohibiting alienability of such essential organs supersedes any contractual consideration. See MuNZeR, supra note 34, at 43.

104. Typical preinvention assignment agreements provide:

The undersigned agrees that he will disclose to the Company all inventions, improvements, software, proeesses, ideas, and mnovations (hereinafter referred to, for convenience only, as "Discoveries"), made or conceived by him, whether or not patentable or copyrightable, either solely or in concert with others, and whether or not made or conceived during working hours, during the period of his employment, which (a) relate to the existing or contemplated business or research activities of the Company; (b) result from the use of the Company's proprietary information, facilities, or resources; or (c) arise out of or result from work performed for the Company. [The undersigned acknowledges that he is employed to engage in research, design, and development.] The undersigned further agrees to keep full and complete records concerning the development of discoveries as above defined and to tender such records to the company upon request.

Robert A. SpanNer, Who OWNS INNOVAtion? The Rights and Obligations of Employers AND EMPLOYEES 120 (1984).

The author of this Comment has signed several preinvention assignment agreements, the latest of which provided, in pertinent part:

2. I hereby agree to disclose promptly to [Company, the employer, a California corporation] and hereby, without further compensations, assign and agree to assign to [Company] or its designee, my entire right, title and interest in, and to all designs, trademarks, discoveries, formula, processes, manufacturing techniques, trade secrets, inventions, improvements, ideas or copyrightable works (the "Proprietary Interests"), including all rights to obtain, register, perfect and enforce these Proprietary Interests

(i) which relate to any of my work during the period of my employment with [Company], whether or not during normal working hours; or

(ii) which pertain to any line of current or anticipated business activity of [Company]; or

(iii) which are aided by the use of time, material or facilities of [Company].

(agreement on file with author). For limitations on the reach of such agreements required by California statute, see infra note 137. For other forms of such agreements, see Cubic Corp. v. Marty, 229 Cal. Rptr. 828, 830 (Ct. App. 1986); Fletcher-Terry Co. v. Grzeika, 473 A.2d 1227, 1228 (Conn. App. Ct. 1984); Ingersoll-Rand Co. v. Ciavatta, 542 A.2d 879, 882, (N.J. 1988); Andreaggi v. Relis, 408 A.2d 455, 458 (N.J. Super. Ct. Ch. Div. 1979). 
made during the employment term, ${ }^{105}$ while others reach only those inventions related to the einployer's business or research interests or made with the assistance of the einployer's resources. In soine cases, these contracts inay extend to periods prior to or subsequent to the einployinent period.

As a general rule, courts uphold preinvention assignment agreements as valid and enforceable contracts. ${ }^{106}$ The agreeinents inay not be enforced, however, if the employer overreaches, for exainple, by attempting to appropriate inventions unrelated in subject matter to the einployment relationship or inventions conceived long after the termination of the employment relationship. ${ }^{107}$

A threshold question in determining the vatidity of a preinvention assignment agreeinent is whether federal or state law applies. Although patents are creatures of federal law, state law is not preempted simply because a patent is at issue. ${ }^{108}$ For example, federal statutory law, which has exclusive control over the inanner in which patents inay be assigned, ${ }^{109}$ contains no provision for the assignment of patents for inventions not yet made. ${ }^{10}$ Thus, agreements to assign patents have no federal statutory basis. ${ }^{111}$ Consequently, "[s]tate law, rather than federal

105. See David Stipp, Lab Legacy: Inventors Are Seeking Bigger Share of Gains from Their Successes, WALl ST. J., Sept. 9, 1982, at 1 ("At [one company], for example, says a spokesman for the ... concern, most employees must sign an agreement specifying, in effect, that 'even if they invent something in their sleep, it belongs to the company." ").

106. See, e.g., United States v. Dubilier Condenser Corp., 289 U.S. 178, 187 (1933) ("A patent is property and title to it can pass only by assignment. If not yet issued an agreement to assign when issued, if valid as a contract, will be specifically enforced."); see also Hovell, supra note 6, at 876-77.

107. See Mislow, supra note 6, at 103; Dratler, supra note 6, at 142 . For examples of overreaching, see Guth v. Minnesota Mining \& Mfg. Co., 72 F.2d 385 (7th Cir. 1934) (holding the portion of an agreement that was limitless in time and subject matter contrary to public policy and hence void); Aspinwall Mfg. Co. v. Gill, 32 F. 697 (C.C.D.N.J. 1887) (invalidating an agreement to assign all the products of one's future labors as an inventor).

108. Aronson v. Quick Point Pencil Co., 440 U.S. 257, 262 (1979).

109. See University Patents, Inc. v. Kligman, 762 F. Supp. 1212, 1219 (E.D. Pa. 1991) ("[A] patent is a creature of federal statutory law [and] may be transferred only in the manner provided by such law.").

110. 35 U.S.C. $\$ 261$ (1988) provides for assignment of "[a]pplications for patent, patents, or any interest therein." A preinvention is a mere expectancy and thus cannot be assigned under this section.

111. Kligman, 762 F. Supp. at 1219 (holding that "contracts to assign patent rights do not have a statutory basis"). Preinvention assignment agreements are agreements to assign expectancies that ripen into transferable property. This concept has parallels in other areas of the law. See, e.g., Eugene F. Scoles \& Edward C. Halbach, JR., Problems and Materials on Decedents ESTATES AND TRUSTS 83 (4th ed. 1987):

An expectancy, being but a hope of succeeding to the property of another living person, is not treated as an existing property interest and therefore cannot be assigned gratuitously. Thus, in a true sense no present transfer of an expectancy is possible. Statutes in some states expressly codify these common law principles. Consequently releases and "assignments" of expectancies can be made binding only under some theory other than that of a present transfer. In appropriate transactions, ... . a court of equity may label the purported assignment an equitable assignment or a specifically enforceable contract to assign. 
patent law, generally governs ownership rights in patentable inventions, including the rights as between an einployer and employee."112

Courts generally enforce preinvention assignment agreements on the basis of freedon-of-contract principles. ${ }^{113}$ Of course, "freedom of contract" is really free only if there is parity of bargaining power between the

Similarly, current tort law forbids trading in unmatured tort claims, that is, claims for accidents that may occur in the future. See Robert Cooter, Towards a Market in Unmatured Tort Claims, 75 VA.

L. REV. 383, 383 (1989).

112. Kligman, 762 F. Supp. at 1219 n.8; see also Aronson v. Quick Point Pencil Co., 440 U.S. 257, 262 (1979) ("Commercial agreements traditionally are the domain of state law. State law is not displaced merely because the contract relates to intellectual property which may or may not be patentable; the states are free to regulate the use of such intellectual property in any manner not inconsistent with federal law."); Donald S. Chisum, The Allocation of Jurisdiction Between State and Federal Courts in Patent Litigation, 46 WASH. L. REv. 633 (1971); Hovell, supra note 6, at 865 n. 13 ("[T]he patent laws do not create a federal common law concerning the pre-invention title to patents.").

Perhaps this is an area where Congress ought to "make a federal case out of it." The analytical distinctions between preinvention and postinvention agreements which justify the application of state law to the former and federal law to the latter are subtle, at best. Furthermore, this is an area where uniformity among the states is desirable.

113. The sentiment of the courts is echoed by one commentator as follows:

A basic policy of contract law is that persons should be able to structure consensual transactions as they see fit and obtain the benefit of any bargains reached. A likely assumption between parties to an employment relationship is that when inventive behavior is part of the agreed relationship, such behavior has already been fully compensated by wages. In a sense, the products of the enployee's mind have already been bought. Having given consideration for inventive services and having assumed the risk that such services might not be successful, the einployer should receive as the benefit of the bargain any resulting intellectual property rights.

6 CHisum, supra note 5, § 22.03[2], at 22-25.

Although preinvention assignment agreements are generally enforced, courts have refused to uphold them under certain factual circnmstances. Assignment clauses may not be enforced (depending in some cases on the jurisdiction), for example, if they: (1) are unartfully drafted, see, eg., Ferroline Corp. v. General Aniline \& Film Corp., 207 F.2d 912, 926 (7th Cir. 1953) (narrowly construing a poorly drafted agreement), cert. denied, 347 U.S. 953 (1954); Motorola, Inc. v. Fairchild Camera and Instrument Corp., 366 F. Supp. 1173, 1179 (D. Ariz. 1973) (finding an agreement impermissibly vague); (2) are oral or implied (for example, through an employee handbook), see, eg., Kligman, 762 F. Supp. at 1220-29 (questioning the enforceability of assignment agreements implied through employee handbooks); (3) unreasonably attempt to bind employees for a period of time following the termination of the employment relationship (so-called "holdover clauses"), see, e.g.. Ingersoll-Rand Co. v. Ciavatta, 542 A.2d 879, 895 (N.J. 1988); (4) are applied to inventions conceived but not reduced to practicc during the term of employment, see, e.g., Jamesbury Corp. v. Worcester Valve Co., 443 F.2d 205, 213 (1st Cir. 1971); (5) are "afterthought" agrcements, see generally Jordan Leibman \& Richard Nathan, The Enforceability of PostEmployment Noncompetition Agreements Formed After at-Will Employment Has Commenced: The "Afterthought" Agreement, 60 S. CAL. L. REv. 1465 (1987); (6) are applicable to inventions that do not relate to the employer's present or anticipated business and that were developed on the employee's own time with the employee's own resources, see infra notes 136.43 and accompanying text (discussing state legislative responses); or (7) are unsupported by consideration other than the continued at-will employment of the employee or otherwise insufficient consideration, see, e.g., Kadis v. Britt, 29 S.E.2d 543, 548 (N.C. 1944) (noting that "consideration eannot be constituted out of something that is given and taken in the same breath-of an employment which need not last longer than the ink is dry upon the signature of the employee"). The position of the Kadis court is distinctly a minority one. 
contracting parties. ${ }^{114}$ This parity may be lacking between employee-inventors and employers. Today, the majority of employment contracts are offered on a "take-it-or-leave-it" basis. ${ }^{115}$ The process by which an employee-inventor agrees to assign her preinvention rights to her employer is not one of hard arms-length bargaining, "but rather of a fly and flypaper."116 As a result, most commentators agree that freedom of contract does not generally exist in the employee-inventor context; that is, preinvention assignment agreements are contracts of adhesion. ${ }^{117}$

The fact that a contract is adhesive does not, however, end the court's inquiry. As one court recently noted in a preinvention assignment agreement context:

The determination that a contract is adhesive is "only the beginning and not the end of the analysis imsofar as enforceability of its terms is concerned." A contract of adhesion can be fully enforced according to its terms unless some other factors exist, such as the oppressive or "unconscionable" provision. Unconscionability includes " ' . . a an absence of meaningful choice on the part of one of the parties together with contract terms which are unreasonably favorable to the other party." "118

There are two types of unconscionability: substantive and procedural. ${ }^{119}$

114. See, e.g., John D. Calamari \& Joseph M. Perillo, Contracts $\$ 1-3$, at 6 (3d ed. 1987) ("Most of contract law is premised upon a model consisting of two alert individuals, mindful of their self-interest, hammering out an agreement by a process of hard bargaining.").

115. Modern contract law has significantly eroded the 19th-century model of unrestricted freedom of contract, particularly in the employment area. Id. Furthermore, employment contracts deserve a higher level of judicial scrutiny than, say, contracts for the sale of commodities, because "[a]fter all, what is being purchased and sold in the labor market is control over the time and activities of a human being." PAUL C. WEILER, GOVERNING tHE WORKPLACE: THE FUTURE OF LABOR AND EMPLOYMENT LAW 21 (1990).

116. Arthur A. Leff, Contract as Thing, 19 AM. U. L. REv. 131, 143 (1970).

117. See e.g., John P. Sutton, Employment Contracts, in LeGAl Righrs OF CHEMISTS AND ENGINEERS 45, 58, 62 (Warren D. Niederhauser \& E. Gerald Meyer eds., 1977):

A contract of adhesion occurs when the terms are prepared entirely for the benefit of one of the parties, and the other party does not have sufficient bargaining power to alter the terms. Today the employment contract is a contract of adhesion. Whether it is enforceable or not depends on whether it is unconscionable...

....

... The problem is that unless you are a Nobel Laureate you are not going to get [fair] provisions into the contract. It's bargaining power that gets fair contract provisions.... Those in demand, like corporation presidents, can write their own tickets. Most employees cannot.

See also Franklin D. Ubell, Assignor Estoppel: A Wrong Turn from Lear, J. PAT. \& TRAdemark OFF. Soc'Y, Jan. 1989, at 26, 27 ("The new employee is compelled to accept such assignment provisions because of the far greater bargaining power of the employer and lack of access to patent counsel. The employee's salary at this point would appear to be dictated by supply and demand in the teeming marketplace for technical talent, rather than by any expectation that the employee will develop valuable patentable inventions.").

118. Cubic Corp. v. Marty, 229 Cal. Rptr. 828, 834 (Ct. App. 1986) (quoting Chretian v. Donald L. Bren Co., 198 Cal. Rptr. 523 (Ct. App. 1984)).

119. See, e.g., Calamari \& Perillo, supra note 114, § 9-40 (distinguishing "substantive" or 
Substantive unconscionability refers to grossly one-sided and oppressive contractual terms; ${ }^{120}$ procedural unconscionability refers to the unfair process through which an agreement is reached. ${ }^{121}$ Preinvention assignment agreements present arguable cases of both types of unconscionability.

A claim of substantive unconscionability must be based on the absence of meaningful choice together with unreasonable contract terms. In the preinvention assignment context, absence of meaningful choice may exist because such agreements are used on an industry-wide basis. ${ }^{122}$ A claim of procedural unconscionability must be based on unfair surprise together, again, with unreasonable contract terms. The unfair surprise in the preinvention assignment context may arise if a valuable invention comes out of the employment relationship even though such an event seemed highly unlikely at the time of contracting. ${ }^{123}$ Many employeeinventors may be quite surprised to find out that they have no rights to their inventions, particularly when the inventions are unrelated to the employer's busmess or not developed on company time. The preinvention assignment agreement thus eviscerates a basic expectation of the employee-inventor.

In the premvention assignment context, both substantive and procedural unconscionability rest ultimately on the reasonableness of the agreement's terms. ${ }^{124}$ Here, reasonableness is determined by analyzing the adequacy of consideration. This analysis is particularly difficult in the preinvention context because the parties are bargaining for something which does not exist and which may never exist, and thus is not easy for the parties to evaluate.

Ex ante bargaining for patent rights in preinventions is difficult due to their speculative nature; the likelilood that any given employee-inventor will invent a truly valuable invention sometime in the future is ex-

"oppressive" unconscionability from "procedural" or "unfair surprise" unconscionability); Melvin A. Eisenberg, The Bargain Principle and Its Limits, 95 HARV. L. REV. 741, 752-53 (1982) (same)

120. Calamari \& Perillo, supra note $114, \S 9-40$.

121. Id. The Marty court is referring, of course, to substantive rather than procedural unconscionability.

122. See, e.g., Marty, $229 \mathrm{Cal}$. Rptr. at 834 (noting that the agreements at issue "are required on an industry-wide basis because the government requires defense contractors to give it title or license in any patents conceived or reduced to practice during the course of performance of government contracts").

123. Thus, the preinvention assignment agreement is in some ways analogous to a liquidated damages provision, where one or both parties are unable (or unlikely) to estimate reasonably the likelihood of breach. Such provisions are often struck down by the courts. For further discussion of the import of the low probability of invention, see infra note 126 and accompanying text.

124. Although courts have listorically been reluctant to review the reasonableness of contraet terms, this reluctance lias been softening in recent years. See, e.g., Eisenberg, supra note 119, at 752 ("Over the last fifteen years, lowever, there lrave been strong indications that the principle of unconscionability authorizes a review of elements well beyond unfair surprise . . .."). 
ceedingly small. ${ }^{125}$ Neither employee-mventor nor employer is likely to evaluate properly the worth of a given employee-mventor's premvention rights ex ante. The employee-inventor will have hittle basis for making a realistic estimate of the likelihood of mvention or of any such invention's value. The employer, particularly the large employer, may have an informational advantage over employee-inventors based on the employer's ability to evaluate preinvention rights statistically over a large sample size. ${ }^{126}$ The employer will probably be unable to account for special attributes of particular employees, and thus will discount the value of preinvention rights of those employees most hikely to be the best inventors. Preinvention assignment agreements are im this way similar to contracts between firms and consumers where the difference in access to information has led to regulation of such contracts. ${ }^{127}$

Ex post bargaining presents equally difficult problems. Even if the total value of the imvention may be agreed upon by the parties, the value of each party's contribution will be difficult to agree upon. The employer will tend to overvalue the contribution of the work environment and the employee-inventor will tend to overvalue her individual contribution.

Some preinvention assignment agreements offer no additional consideration for the assignment of an employee-inventor's mvention to the employer beyond the continued employment of the employee. ${ }^{128}$ Most courts hold that even this is adequate consideration, simce the employeeinventor is dischargeable "at will."129 Certainly, there is no requirement that the consideration approximate the value of the mvention, though some courts may find that nominal consideration is inadequate. ${ }^{130}$

125. See Rebecca S. Eisenberg, Proprietary Rights and the Norms of Science in Biotechnology Research, 97 YALE L.J. 177, 217 (1987) ("The serendipitous nature of research discoveries may make it difficult to place a value on the right to use a patented invention before the outcome of a research project is known.").

126. Commentators note that contracting parties systematically tend to underestimate the likelihood of low-probability events, and that this tendency makes judicial intervention appropriate for long-term contracts. See, e.g., Melvin A. Eisenberg, The Structure of Corporation Law, 89 Colum. L. REV. 1461, 1464-65 (1989). While the likelihood of a significant invention is a lowprobability event for the employee-inventor, it is a high-probability event for the typical employer who has a diversified inventor portfolio.

127. See generally Alan Schwartz \& Louis L. Wilde, Imperfect Information in Markets for Contract Terms: The Examples of Warranties and Security Interests, 69 VA. L. REv. 1387 (1983) (discussing contracts between firms and consumers and the role of imperfect information).

128. See VAUGHAN, supra note 74, at 34 ("The hired inventors and technicians of business corporations generally receive only salaries for compensation ...."). This Comment assumes that the agreement is of the no-additional-consideration type. Of course, some, if not most, corporations will offer some additional compensation for patents applied for and/or granted. However, this additional compensation is often part of a separate "invention incentive" plan rather than part of the preinvention assignment agreement, and rarely bares any relationship to the actual value of the invention.

129. Mislow, supra note 6 , at 100 . The continuation of the at-will employment, therefore, constitutes consideration for the patent assignment.

130. Id. at 102 . 
Is continued at-will einployment adequate consideration for the assignment of valuable patents? Take the case of an employee-inventor who agrees to a preinvention assignment clause but never develops a patentable invention. Is she in breach of her contract? Almost certainly she is not. ${ }^{131}$ The employer cannot reasonably expect that a particular einployee-inventor will conceive of a valuable patentable invention. After all, a patentable invention, by definition, must be unanticipated (that is, "novel" and "non-obvious"). ${ }^{132}$ Similarly, most employee-inventors do not consider it likely that they will conceive of a valuable patentable invention. Thus, the terms of the assignment clause are probably not of utmost importance at the time of the contract's formation. It is therefore unlikely that either employee-inventor or einployer really mistakes continued employment as consideration for the assigninent of valuable patents by the employee-inventor.

This Section has discussed how einployers use their bargaining advantage over employee-inventors to appropriate rights in inventions that would otherwise accrue to the employee-inventors under the cominon law formulation. The prevalence of preinvention assignment agreements can be attributed to a form of market failure: labor monopsony. ${ }^{133}$ There is, in effect, no market for techincal jobs that does not require relinquishment of premvention rights. This inarket failure has eviscerated the policy of individual incentive and recognition implicit in a Patent Code that recognizes only human inventors. ${ }^{134}$ Because failures of the self-regulatory mechanism of the market are viewed as appropriate occasions for public regulation, ${ }^{135}$ state and federal legislators have initiated several responses to the probiferation of preinvention assignment agreements. These responses will be examined in the following Section.

131. I am unaware of any cases where an employee's failure to create valuable, patentable inventions was asserted as a breach of an employment contract or used as evidence of cause for termination.

132. See supra notes 23-24 and accompanying text.

133. See, e.g., Richard A. Posner, Economic ANAlysis of LAw 299-300 (3d ed. 1986) (describing labor monopsony as a form of market failure, though Judge Posner does not believe labor monopsony is a serious problem today in this country). Employers can typically exercise considerably more power over employees than they can over, say, consumers because jobs, especially jobs for employees with highly specialized skills, are less fungible than most products. See, e.g., WEILER, supra note 115, at 21-22; Parker, supra note 6, at 608-09.

134. Contractual evisceration of governmental policies is not unique to the preinvention assignment agreement context. For example, corporate subsidized insurance and routine indemnification of direetors and managers have collapsed the dual liability regime of corporate law whereby firms and their agents are jointly and severally liable for crimes and torts committed within the scope of the agent's employment. See, e.g., Reinier H. Kraakman, Corporate Liability Strategies and the Costs of Legal Controls, 93 YALE L.J. 857, 859 (1984).

135. See POSNER, supra note 133 , at 343. 


\section{Legislative Responses to Preinvention Assignment Agreements}

To date, five states have enacted legislation to limit the reach of preinvention assignment agreements. ${ }^{136}$ The statutes all require some relationship between the employee-imventor's invention and the employer's resources, or its present or contemplated busmess areas, in order to justify mandatory assignment. ${ }^{137}$ None of the state statutes, however, give employee-inventors any rights to imventions related to the work that the employee-inventor was hired to perform for the einployer.

The state statutes have been effective in restrictimg einployers from overreaching or appropriating inventions of employee-mventors where those inventions do not relate to the employer's actual or anticipated lime of business or research. It is reasonable to expect, however, that most inventions-particularly most important inventions-an employee-inventor might produce would relate to the employer's business, and more specifically, to the actual work the einployee-inventor performs for the employer; after all, this is the area of the einployee-inventor's expertise and focus. ${ }^{138}$ Thus, the state statutes by design do not reach the most important imventions of einployee-inventors.

Federal legislation to reform patent law with respect to private sector employee-mventors has been proposed at least nime times since 1963. ${ }^{139}$ The proposed bills ranged from a return to the common law allocation of patent rights ${ }^{140}$ to mandatory compensation for employee-

136. These states are California, Illinois, Minnesota, North Carolina, and Washington. See Cal. Lab. Code $\S \S 2870-2872$ (West Supp. 1992); Ill. Rev. StaT. ch. 140, para. 302 (1991); Minn. Stat. $§ 181.78$ (Supp. 1991); N.C. Gen. Stat. $\S \S 66-57.1, .2$ (1991); WaSh. Rev. CodE ANN. $\$ \S 49.44 .140, .150$ (West Supp. 1991).

137. For example, the California statute makes inoperative any preinvention assignment agreement as applied to inventions made on the employee-inventor's own time and with the employee-inventor's own resources unless, at the time of conception or reduction to practice, the invention relates to the employer's business or anticipated research or developinent, or unless the invention resulted froin work performed by the employee for the employer. CAL. LAB. CoDE $\S 2870($ a).

The second preinvention assignment agreement set forth supra note 104, which was controlled by California law, contained the following provision:

3. I understand and agree that the foregoing does not apply to an invention for which no equipment, supplies, facility or trade secret information of [Company] was used and which was developed entirely on iny own time, and which does not relate (1) to the business of [Company], or (2) to the actual or demonstrably anticipated research or development of [Company], or (3) which does not result from any work performed by ine for [Company], or (4) any invention which qualifies fully under the provision of California Labor Code Section 2870 , a copy of which has been provided to me as an attachment to iny copy of this agreeinent.

138. By "important" inventions, I refer both to inventions that are of economic significance as well as to inventions that are of the greatest personal importance to the employee. The latter concept will be addressed infra Part IV, in the discussion of "personhood" interests in inventions.

139. See Parker, supra note 6, at 617-19. For a discussion of the history of the proposed federal reforms, see id. See also Witte \& Guttag, supra note 6, at 467-81.

140. See, e.g., H.R. 4392, 88th Cong., 1st Sess. (1963). 
inventors who assign patent rights to employers. ${ }^{141}$ None of these proposals has been enacted. It is unlikely that such legislation will be enacted in the foreseeable future due to the strong lobbying efforts of corporate employers. ${ }^{142}$ Moreover, engineer- and scientist-employees and potential employees represent a diffuse and poorly organized lobby. ${ }^{143}$

This Part has discussed the failure of patent and contract doctrine to resolve adequately the problein of the employee-inventor. Patent law is limited by its antiquated and rigid conception of inventorship. Under its current formulation, patent law does not address the inventorship environments in which today's employee-inventors operate. Similarly, contract law is limited by its wooden application of freedom-of-contract principles to situations in which inarket failure has inade such principles inappropriate. In addition, contract law analysis fails to address the underlying property issues inplicated by preinvention assignment agreements. Finally, federal and state reforms have not resolved the problems of premvention assignment agreements because policymakers have viewed the dispute in terms of inadequate contract or patent doctrine.

Part III will look beyond doctrine to theory in an attempt to resolve premvention assignment disputes. Several traditional private property justifications will be examined in the context of preinvention assignment disputes.

141. See, e.g., H.R. 3285, 98th Cong., 1st Sess. (1983); S. 1321, 93d Cong., 1st Sess. § 263, 119 CONG. REC. 9102, 9113 (1973); H.R. 15,512, 91st Cong., 1st Sess. (1970).

142. See, e.g., Innovation and Patent Law Reform: Hearings Before the Subcomm. on Courts, Civil Liberties, and the Administration of Justice of the House Comm. on the Judiciary, 98th Cong., 2d Sess. (1984) [hereinafter Invention and Patent Law Reform] (containing the testimony and statements of many industry representatives opposing legislation establishing a mandatory compensation scheme for employee-inventors). Interestingly, however, the Technology Transfer Act of 1986 enacted, among other provisions, mandatory compensation for inventors employed by the federal government, including a forced minimum $15 \%$ share for inventors of any royalties or income received by the government for the inventions of its employee-inventors. 15 U.S.C. $\$ 3710 \mathrm{c}$ (1988). The legislative history of the Act, however, specifically provides: "Some representatives of businesses that employ scientists fear that establishing royalty sharing for Federal employees will set a precedent for legislation mandating royalty sharing for private inventors. ... The Committee does not intend for this provision affecting Government employees to set a precedent for private employees." S. REP. No. 283, 99th Cong., 2d Sess. 13 (1986), reprinted in 1986 U.S.C.C.A.N. 3442, 3455.

143. But see Innovation and Patent Law Reform, supra note 142 (testimony of several representatives of professional technical employees supporting proposed legislation establishing a mandatory compensation scheme for employee-inventors); Rights of Employed Inventors: Hcaring Before the Subcomm. on Courts, Civil Liberties, and the Administration of Justice of the House Comm. on the Judiciary, 97th Cong., 2d Sess. 21-53 (1982) (same). 
III

The Limitations of Theory: The EMPloyee-INVENToR and Preinvention AssignMent Agreements UNDER TRADITIONAL THEORIES OF PROPERTY

As discussed in Part II, commentators, judges, and legislators have been aware for years of the limitations of patent and contract doctrine as applied to the employee-inventor. Yet hittle significant refornn has occurred at judicial or legislative levels. Although there are possible structural explanations for the lack of reform, ${ }^{144}$ this Comment will focus on a theoretical explanation: that preinvention assignment disputes are ultimately a property law problein rather than a contract or patent law problem, and that traditional property law itself is ill-equipped to resolve these disputes.

This Part will examine how, although preinventions share inany of the attributes of real and personal property, ${ }^{145}$ traditional property law theory is of limited utility due to the distinctive nature of the property and the manner in which the property is created within the employeremployee relationship. Although they are ultimately rejected, traditional property law theories are useful for illuminating the strengths and weaknesses of the approach advocated in Part IV: the removal of an einployee-imventor's future imventions froin a contract-law-only regime (a regime of full inarket alienability) to a property law regime (a regime of partial inarket inalienability).

\section{A. The Distinctive Nature of Intellectual Property}

An appreciation of the distinctive nature of intellectual property is a necessary prerequisite to the application of property theories to preinvention disputes. This Section will briefly describe those attributes of intellectual property that distinguish it from other forins of property, such as real property and tangible personal property.

The Patent Code provides that "patents shall have the attributes of personal property." 146 Patents, and indeed, all forms of intellectual property have some of the attributes of personal or tangible property, such as the right to exclude and the right to alienate. However, there are significant differences between the nature of intellectual property and that of personal or tangible property. Because of these differences, some of the property rules that govern tangible property may be inappropriate for intellectual property.

Several distmctive aspects of intellectual property are of particular

144. See, e.g., supra notes $142-43$ and accompanying text.

145. See, e.g., Frank H. Easterbrook, Intellectual Property Is Still Property, 13 HARV. J.L. \& Pub. Pol'y 108, 112-13 (1990).

146. 35 U.S.C. $\$ 261$ (1988). 
significance in the preinvention context: intellectual property has both "free good" and "public good" attributes; ${ }^{147}$ intellectual property rights are of limited scope; $;^{148}$ and intellectual property rights have traditionally been thought of as a "deinocratic" form of property. ${ }^{149}$ These aspects of intellectual property inust be considered as part of any proposed resolution to preinvention assignment agreeinent disputes. ${ }^{150}$

147. An idea can be used and enjoyed by many people at any given time without depriving other people of use or enjoyment of the idea, and thus has the attributes of an inexhaustible resource, or, in economic terms, a "free good." See DRATLER, supra note $25, \$ 1.01[1]$. Ideas are inexhaustible in another sense: the potential number of ideas is unlimited. At the same time, it is difficult to prevent others from using an idea once it is divulged and thus, like clean air or national defense, ideas have the attributes of a "public good." Therefore, ideas may be utilized by "free riders" who did not share in the cost of producing the information. Because ideas can be public goods, intellectual property protection is necessary to prevent an informational "tragedy of the commons." As one commentator has noted, "Assuming rational investors, absolute freedom to use information, i.e. an informational commons, could only result in there being no information worth using. Valuable information, i.e. information that is the result of purposive investunent in learning, therefore depends upon the existence of private property rights." WILLIAM KINGSTON, INNOVATION, CREATIVITY AND LAW 83 (1990).

148. Intellectual property rights are more limited in scope than are many tangible property rights. Intellectual property rights are of limited duration; tangible property rights, particularly in real property, are of unlimited duration. Even though some interests in tangible property may be of limited duration, the property vests in somebody indefinitely. The rights of ownership of intellectual property are inore circumscribed than are those in other forms of property. For exaunple, while a landowner has the right to possess the land, to exclude others, to clispose of the land, to use the land, to enjoy the fruits of the land, and to destroy, harm, or alter the land, a patent owner has only the right to exclude others from inaking, using, and selling the subject matter of the patent, and, in most cases (though not all), the right to dispose of the patent.

149. Traditionally, tangible property, particularly real property, has been a device for concentrating wealth within families and for the maintenance of the status quo. Tangible property tends to perpetuate social stratification through primogeniture. Justin Hughes, The Philosophy of Intellectual Property, 77 GEo. L.J. 287, 290-91 (1988). Intellectual property, on the other hand, due to its means of creation and its limited duration is in theory wealth-redistributive or at least more wealth-neutral. Id. at 291. Intellectual property, then, is a "demccratic" form of property; that is, it is a form of property obtainable by all citizens. See Hugo A. Meier, Thomas Jefferson and a Democratic Technology, in TECHNOLogY IN AMERICA, supra note 59, at 17, 28-30 (discussing Jefferson's behief that inventions should not be monopolized). Consider, too, the following remarks, made on the 150th anniversary of the patent system:

The success of our patent system is due to the fact that it is essentially democratic. Patents are granted as a matter of right and a good patent makes the little man an effective competitor of the big man. Our patents are, unlike others, not used for tariff purposes and are not burdened by taxes; nor are the exclusive rights granted for a limited period diluted by requirements for compulsory licenses or compulsory workings. These considerations have inade us a nation of inventors, for even the least of us has the opportunity by creative thought to take his place among the grcat. The perpetuation of that system and the maintenance of the standard of living that we enjoy require that research and invention must continue to be encouraged and protected.

William B. Kerkam, Some Historical and Current Reflections on the American Patent System, in United States Patent Law Sesquicentennial Celebration, supra note 73, at 8, 9.

150. Although the differences between intellectual property and tangible property were understood at the time the first Patent Act was drafted, they were not of great significance because nost valuable property was tangible property. This is no longer the case today. Intellectual property is becoming increasingly valuable relative to tangible property. As one eommentator recently noted:

[A] profound reallocation of wealth has been under way during the past thirty years. 


\section{B. Traditional Property Theories}

Although a number of theories have been put forth to justify the concept of private property, ${ }^{151}$ those inost frequently invoked are based on either natural law or utilitarian foundations. There is a certain tension between these two bases, for, as will be demonstrated, natural law focuses on the rights of individuals at the expense of the general welfare of society, whereas utilitarianism emphasizes general welfare at the expense of individual right. ${ }^{152}$ This dichotomy may help to explain why neither theory is particularly helpful in resolving preinvention assignment disputes, for both employers and employee-inventors can make legitimate and persuasive imdividual rights and general welfare arguments.

\section{Natural Law Justifications}

The term "natural rights" refers to universally recognized rights attributable to human nature or to immutable conceptions of "reason" rather than to the enactment of statute. ${ }^{153}$ The Declaration of Independence, for exainple, is based on a natural rights justification. ${ }^{154}$ Although the Declaration of Independence does not speak directly of natural rights in property (except obhiquely through the phrase "pursuit of happiness"), such rights were widely regarded as self-evident in eighteenth- and nineteenth-century America: "It may then be taken as an

Increasingly, wealth is being defined in terms of intangible property: information and things done with information.

... The traditional forms of intangible property, patents and copyrights, do have their own statutory schemes for ownership and transfer, but these eighteenth century mechanisms hardly provide an ideal inodel for the future .... [T] hey were enacted as analogs to the rules which regulate real and personal property and as such they fail to account for the essential difference between tangible and intangible property; namely, that one loses value when it is divided while the other does not.

Samuel J. Sutton, Book Review, 31 JuR1METRICS J. 357, 357-58 (1991).

151. These theories include first occupancy or discovery, labor theory, personality theory, utilitarian theory, and critical legal studies. See JESSE DUKEMINIER \& JAMES E. KRIER, PROPERTY 132-41 (2d ed. 1988).

152. See AlaN Ryan, Property 70 (1987).

153. See, e.g., Phillip E. Johnson, Some Thoughts About Natural Law, 75 CALIF. L. REV. 217, 217 (1987) ("[A]nyone who attempts to found concepts of justice upon reason and human nature engages in natural law philosophy."). For various formulations of natural rights, see John Christman, Can Ownership Be Justified by Natural Rights?, 15 PHIL. \& PuB. AFF. 156 (1986). Christman identifies a "strong sense" of natural right as a "right if and only if persons would have this right in a state of nature, prior to, and independent of, the establishment of any civil or political institution." Id. at 157. He identifies a "weak sense" of natural right as a right " "not created or conferred by men's voluntary action,' that is, it is not a right which is derived from positive law or social institutions." Id. at 158 (quoting H.L.A. Hart, Are There Any Natural Rights?, in RIGHTs 15 (David Lyons ed., 1979)). These are all conteinporary secularized formulations of natural law. Historically, natural law had been conceptualized as the law of God (the "author" of both man and justice). See, e.g., Alan Ryan, Property AND Polmtical Theory 14-48 (1984) (discussing the relationship between Locke's labor theories of property and the purposes of God).

154. "We hold these truths to be self-evident; that all men are created equal; that they are endowed by their creator with certain inalienable rights; that among these are life, liberty, and the pursuit of happiness . . . " The DECLARATION OF INDEPENDENCE para. 2 (U.S. 1776). 
established proposition that wliatever thing tliat is property-subject-matter which a man makes out of materials belonging to no one else, is his exclusive property by natural right."155

Natural rights form the basis of a common law riglit of inventors to use their inventions. ${ }^{156}$ The natural riglit and common law right are often treated intercliangeably, ${ }^{157}$ and will be so treated liere. The relationship between natural or common law rights im inventions and statutory rights conferred by patents ouglit not to be confused, liowever. The natural law or common law right is the riglit of an inventor to inake, use, or sell her invention. ${ }^{158}$ This riglit is non-exclusive. An inventor's natural right does not preclude otliers from making, using, or selling the invention, once the invention is disclosed to the public. ${ }^{159}$ The patent right (if held by tlie inventor) is broader tlian tlie common law right, for it is the patent that grants the riglit to exclude otliers froin making, using, or selling tlie invention. ${ }^{160}$

Therefore, although natural rights in inventions are recognized by the courts, they inay be extmguished or suppressed througli patents or by other statutes. ${ }^{161}$ Since patent riglits are granted, if at all, to the first inventor of an idea, ${ }^{162}$ the natural rights of later independent inventors of equivalent inventions are temporarily suppressed by the patent rights of tlie former. ${ }^{163}$ Exclusive rights in inventions are not only distinct from

155. William E. Simonds, Natural Right of Property in Intellectual Production, 1 XALE L.J. 16, 17 (1891).

156. See, e.g., The Federalist No. 43, at 309 (James Madison) (Benjamin F. Wright ed., 1961) ("The utility of [the Patent and Copyright Clause] will scarcely be questioned. The copyright of authors has been solemnly adjudged, in Great Britain, to be a right of common law. The right to useful inventions seems with equal reason to belong to the inventors.").

157. See, e.g., Arachnid, Inc. v. Merit Indus., 939 F.2d 1574, 1578 (Fed. Cir. 1991) ("[T]he act of invention itself vests an inventor with a common law or 'natural' right to make, use and sell his or her invention ....").

158. See id.

159. See William C. Robinson, Patents $\$ 24$ (1890), quoted in Robert A. Choate et Al., PATENT LAW 2 (3d ed. 1987) ("An idea once communicated can no longer be exclusively appropriated and enjoyed. ... Under the laws of nature the exclusive public use of an invention is thus impossible, and hence there is no natural right to such a use."); see also RoBinson, supra, $\S 25$, quoted in CHOATE ET AL., supra, at 3 ("The natural right of the public to appropriate all new ideas that may be voluntarily disclosed is no less evident than that of the inventor to conceal them. It is a law of nature that men should profit by the discoveries and inventions of each other.").

160. See Arachnid, 939 F.2d at 1578-79 ("A patent in effect enlarges the natural right, adding to it the right to exclude others from making, using or selling the patented invention. . . . [O]wnership only of the invention gives no right to exclude, which is obtained only from the patent grant.") (citation omitted); see also Gayler v. Wilder, 51 U.S. (10 How.) 477, 493 (1850) ("The inventor of a new and useful improvement certainly has no exclusive right to it, until he obtains a patent. This right is created by the patent, and no suit can be maintained by the inventor against any one for using it before the patent is issued.").

161. See Simonds, supra note 155 , at $23-25$.

162. 35 U.S.C. $\$ 102$ (1988).

163. See, e.g., Crown Die \& Tool Co. v. Nye Tool \& Mach. Works, 261 U.S. 24, 30 (1923):

The most common case of the separation of the patent and natural rights is where the structure of the patent in suit is dominated by some other and broader patent. The broader 
natural rights in inventions, they are also "at odds with the inherently free nature of disclosed ideas." 164 Furthermore, any natural rights justification for ownership of ideas would seem to be offset by a natural rights argument to copy the ideas of others. ${ }^{165}$

The distinction between the natural rights of inventors and patent rights granted by statute, however, does not rule out a natural rights basis in patents. The "embarrassment of an exclusive patent"166 must be justified on some sound, reasoned, moral basis. ${ }^{167}$ Natural rights could provide such a justification; that is, by enacting the Patent Act, Congress could have been trying to protect or codify the natural rights of inventors.

The natural right of inventors to the use of their inventions has long been recognized, usually conceptualized as a form of first occupancy or discovery. ${ }^{168}$ Natural rights also form the basis for otlier justifications of private property, such as the labor justification. ${ }^{169}$ Often, however, natural rights are asserted as an undifferentiated justification for intellectual property. First occupancy and undifferentiated natural rights justifica-

\footnotetext{
patent may be older or younger or of the same date with the narrower patent. In either case, for the whole life of the broader patent, and this may be the whole life of the narrower patent as well, the patentee of the narrower patent has no natural right to make, use or sell the structure of his own patent. ...

The exclusive right and the natural right flow from different sources, are of different kinds and need not co-exist. It is impossible to maintain any clean-cut line of patent law unless we totally divorce the two rights, and, in discussing the patent right, assume that the natural right is immaterial.
}

The separation between natural law and patent law property rights was further elaborated in Graham v. John Deere Co., 383 U.S. 1, 9 (1966):

The patent monopoly was not designed to seeure to the inventor his natural right in his discoveries. Rather, it was a reward, an inducement, to bring forth new knowledge. The grant of an exclusive right to an invention was the creation of society-at odds with the inherent free nature of disclosed ideas-and was not to be freely given.

Note that since copyright protects the form of expression rather than the idea itself, natural law can be used as a justification for copyright protection. See Simonds, supra note 155, at 24.

164. Graham, 383 U.S. at 9.

165. From the beginning of history, ideas have been shared, particularly in the realm of common defense, gathering food, building shelters, and clothing man.

Thus, it is "natural" both that persons with ideas and skills use them to their own advantage, and that other persons copy what they observe. . .

....

Regardless of any "natural" rights that artisans or tradesmen had in their own ideas, skills and inventions, these rights could not be profitably utilized without some means of protection and enforcement due to the "natural" right of others to copy what they observed.

ChOATE ET AL., supra note 159, at 1-3.

166. Letter from Thomas Jefferson to Isaac McPherson, The Invention of Elevators, (Aug. 13, 1813), in The Writings of Thomas JefFerson 329, 335 (Saul K. Padover ed., 1967).

167. Lawrence C. Becker, Property Rights 22-23 (1977); see also Munzer, supra note 34 , at 1-12.

168. See, e.g., 2 William Blackstone, Commentaries *400-07 (including patents and copyrights with goods captured from alien enemies, things found, and animals wild by nature as having title by occupancy).

169. See infra Section III. B.1.b. 
tions and their application to preinventions will be discussed first, followed by a discussion of labor theory.

\section{a. First Occupancy Justifications}

First occupancy represents one potential natural- rights-based justification for patent rights. The first occupancy justification proposes that previously unowned property belongs to the first party to "occupy" the property. ${ }^{170}$ Property justifications based on first occupancy have, however, been widely criticized. ${ }^{171}$ First occupancy provides a satisfactory justification for private property ownership, it has been argued, only when certain conditions are inet; two such conditions are: "(1) the object occupied is unowned; and (2) occupation is in some relevant sense actual as opposed to intentional or declaratory." ${ }^{172}$ Neither condition is satisfied in the case of preinvention assignment agreements.

The first requirement for first occupancy seemingly cannot be resolved in the preinvention assignment context. An invention is, of course, unowned until invented; once invented, however, it can be claimed iminediately by both employee-inventor and employer. Each can claim a natural right as "inventor" based upon first occupancy. ${ }^{173}$ Thus, while natural rights arguments may support patent rights for inventor-entities as against society, natural rights do not appear helpful in justifying patent rights of employee-inventors as against their employers (or vice versa). In the parlance of property law, the act of invention by an employee-inventor does not create a single first occupant but rather a joint first occupancy in the property.

The second requirement for first occupancy-actual occupancy (or exploitation) of the invention-is not a condition precedent to enforcement of patent rights under current patent law. Thus, a corporation could sue an inventor for infringing a patent issued for her invention (assuming that patent had been assigned to the corporation) merely on the basis of the corporation's status as patent holder. There need be no showing that the corporation ever had any intent to make, use, or sell the

170. See BECKER, supra note 167 , at 24-26.

171. See, e.g., id. at 24-31 (arguing that "being there first" is not a sound basis for claims to ownership); DUKEMINIER \& KRIER, supra note 151, at 133 (noting that first occupancy provides a weak normative justification for private property, though it fares somewhat better as a descriptivc or explanatory theory of the origins of private property).

172. BECKER, supra note 167 , at 24. Becker lists two other requirements for first occupancy to be a supportable justification of private property: "(3) the concept of actual occupation defines with reasonable clarity how much one can occupy; and (4) the occupier claims no more than a share as defined by (3)." Id. The latter two requirements do not preclude first occupancy as a justification when applied to preinvention disputes.

173. The assumption here is that, for natural rights purposes, the employer (if a corporation) would not be limited to the statutory definition of inventor contained within the Patent Code which precludes corporate inventorship. In other words, it is assumed that it is possible for a corporation to have a natural right in an invention. 
invention. In other words, contrary to the requirements of first occupancy, ownership can be based on a declaratory occupancy. ${ }^{174}$

\section{b. Normative Labor Justifications}

The labor theory is the predominant property justification articulated in Anglo-American jurisprudence and philosophy ${ }^{175}$ and thus requires careful consideration when analyzing the property issues at stake in preinvention disputes. The labor theory is generally attributed to John Locke and the influential chapter on property in his Second Treatise of Government. ${ }^{176}$ Locke's theory has both a normative and an instrumental justification. ${ }^{177}$ The normative justification maintains that society rewards labor with property because labor is unpleasant and should be rewarded, ${ }^{178}$ whereas the instrumental justification maintains that society rewards labor with property because labor (the expenditure of which is beneficial to society) is unpleasant and would not be expended without reward. ${ }^{179}$ Although the two justifications are clearly distinct, it can often be difficult to determine which theory is being invoked by the courts. ${ }^{180}$ In order to avoid such confusion, ouly the normative justifica-

174. It should be noted that some commentators continue to find natural rights support for intellectual property. For example, it has been asserted that the constitutional language of "securing" patent and copyright rights may imply a recognition of a natural rights basis in intelleetual property. See Dratler, supra note 6, at 140 n.46 (citing Ramsey, The Historical Background of Patents, 18 J. PAT. OFF. Soc'Y 6, 14-20 (1936)); see also Sutton, supra note 117, at 50 (" 'Everyone has the right to the protection of the moral and material interests resulting from any scientific, literary, or artistic production of which he is the author.' ") (quoting Universal Declaration of Human Rights, art. 27(2), adopted by U.N. General Assembly, Dec. 10, 1948); Amber L. Hatfield, Note, Life After Death for Assignor Estoppel: Per Se Application to Protect Incentives to Innovate, 68 TEX. L. REV. 251, 256 (1989) (discussing constitutional language in support of natural rights arguments). This support of natural rights in inventions, however, must be recognized as a justification of property rights of inventor-entities as against society and not as a justification for exclusive rights of either the employee-inventor or the employer.

175. See, e.g., BECKER, supra note 167, at 32; GRUNEBAUM, supra note 35, at 52.

176. John Locke, The Second TReatise of Government 16-30 (Thomas P. Peardon ed., 1952) (1690).

177. Labor theories of property are sometimes divided into "avoidance" theories and "labordesert" categories, each with normative and instrumental aspects. See Hughes, supra note 149, at 302-10. I feel that it is more helpful to divide labor theories into normative and instrumental categories.

178. Hughes, supra note 149, at 296.

179. Id.

180. Few Supreme Court cases have clearly articulated the distinction between the normative and instrumental purposes underlying patent law. Some cases, particularly the earlier ones, expressly adopted the normative argument. See, e.g., Brown v. Duchesne, 60 U.S. (19 How.) 183, 195 (1857) (stating that patent laws "secure to the inventor a just remuneration from those who derive a profit or advantage, within the United States, from his genius and mental labors"); Scott Paper Co. v. Marcalus Co., 326 U.S. 249, 255 (1945) (stating that "by the patent laws Congress has given to the inventor opportunity to secure the material rewards for his invention"); see also Brenner v. Manson, 383 U.S. 519, 536 (1966) ("[A patent] is not a reward for the search, but compensation for its successful conclusion."). Others offered normative arguments as important, though secondary to instrumental arguments. See, e.g., Zacchini v. Scripps-Howard Broadcasting Co., 433 U.S. 562, 577 (1977) (although " 'reward to the [inventor may be] a secondary consideration,' . . . [patent 
tion will be discussed under this heading; the instrumental (or utilitarian) justification will be addressed under a separate heading.

In his Second Treatise, Locke articulates three distinct but related normative labor justifications for property. ${ }^{181}$ The first normative justification-referred to here as the basic labor justification-proceeds in three steps:

(1) one's body is one's property;

(2) thus, one's labor-the product of one's body-must be one's property;

(3) thus, the product of one's labor must also be one's property..$^{182}$

The second justification-referred to here as the "value-added" justification-clains that one's labor, which is one's property, adds value to things as they exist in their natural unlabored-upon state, and this addition of value justifies property in the thing labored upon. ${ }^{183}$ The third justification-referred to here as the "labor-desert" justification-maintains that one's labor, which is one's property, adds value to things as they exist im their natural unlabored-upon state, and it would be unjust for others to appropriate the benefit of one's labors, so long as the laborer

protection was] 'intended definitely to grant valuable, enforceable rights.' ") (citations omitted). Still others clearly favored the instrumental theory over the normative. See, e.g., Motion Picture Patents Co. v. Universal Film Mfg. Co., 243 U.S. 502, 511 (1917) (emphasizing that the Supremc Court "has consistently held that the primary purpose of our patent laws is not the creation of private fortunes for the owners of patents but is "to promote the progress of science and useful arts," (quoting U.S. CoNST. art. I, $\S 8, \mathrm{cl} .8$ ), while noting that inventors are to be "fairly, even liberally, treated").

In some cases, it appeared that the court offered both justifications without preference. For example, in Grant v. Raymond, 31 U.S. (6 Pet.) 218, 242-43 (1832), Chief Justice Marshall stated that a patent is

the reward stipulated for the advantages derived by the public for the exertions of the individual, and is intended as a stimulus to those exertions. . . .

....

... The great object and intention of the [patent] act is to secure to the public the advantages to be derived from the discoveries of individuals, and the means it employs are the compensation made to those individuals for the time and labour devoted to thesc discoveries.

The imprecise manner in which courts and commentators invoke labor justifications for intellectual property provides little theoretical guidance for the resolution of preinvention assigninent disputes.

181. LocKE, supra note 176, at 17-24. The description of Locke's normative labor theories draws heavily upon BECKER, supra note 167 , at $32-43$.

182. Or in Locke's own words:

[E]very man has a property in his own person; this nobody has any right to but himself. The labor of his body and the work of his hands, we may say, are properly his. Whatsoever then he removes out of the state that nature has provided and left it in, he has mixed his labor with, and joined to it something that is his own, and thereby makes it his property. It being by him removed from the common state nature has placed it in, it has by this labor something annexed to it that excludes the common right of other inen. For this labor being the unquestionable property of the laborer, no man but he can have a right to what that is once joined to, at least where there is enough and as good left in common for others. LOCKE, supra note 176 , at 17.

183. Id. at 18. Note that the "value-added" justification is a variant of the basic labor justification. 
leaves "enough and as good" in the commons for others. ${ }^{184}$

Although Locke's normative labor justifications have come under some criticism from commentators, ${ }^{185}$ each provides powerful arguments in support of allocating intellectual property rights to inventors rather than to society. ${ }^{186}$ However, the issue underlying preinvention assignment disputes is not whether society should allocate intellectual property rights, but rather, how society should allocate such rights. None of Locke's normative justifications provides a satisfactory answer. Instead, the justifications raise additional questions. Who is the laborer under the basic labor justification: the employee-inventor or the employer? What added the value under the value-added justification: the employee-inventor's personal capital or the employer's financial capital? And who deserves to be rewarded under the labor-desert justification? Once again, the lack of a ineaningful legal definition of inventorship-one that reflects contemporary models of invention-stands in the way of a satisfactory resolution.

\section{Utilitarian (or Instrumental) Labor Justifications}

Instrumental justifications ${ }^{187}$ have long been recognized as the basis for both statutory and common law intellectual property rights. ${ }^{188}$ In fact, the usual justification for intellectual property in general, and the patent system in particular, is an instrumental one: society rewards inventors with patents (that is, provides exclusive rights to make, use, or

184. Id. at 20-21. The "labor-desert" justification is also a variant of the basic labor justification.

185. Robert Nozick, for example, asks why one should expect that mixing one's labor with a thing results in ownership of the thing rather than in loss of one's labor. ROBERT NozICK, ANARCHY, STATE, AND UTOPIA 174-75 (1974).

186. Such arguments are based on four basic propositions: (1) inventions require labor; (2) inventions generally have some value to society; (3) one invention does not deplete the "commons" of potential future inventions; and (4) intellectual property rights are necessary to prevent appropriation of the "public good" aspect of the invention. Few would dispute the verity of the first and second propositions, and the third and fourth propositions were identified earlier as general characteristics of intellectual property. See supra note 147 and accompanying text.

Some commentators do question, however, the application of labor theory as a justification for intellectual property rights. See, e.g., BECKER, supra note 167, at 47 (raising some concerns regarding the application of normative labor justifications to intellectual property, such as why certain classes of ideas are protected while others are unprotected, and why patents and copyrights expire after a term of years when rights in other property aequired by labor do not expire).

187. Instrumental justifications are similar to, but distinguishable from, utilitarian justifications. Utilitarian justifications for private property are based on the assumption that private property is necessary in order to achieve utility, or "human happiness." See, e.g., BECKER, supra note 167, at 57. Traditionally, this definition included a broad range of human social welfare concerns, but due to the difficulty of measuring most forms of human satisfaction, a narrower form of utilitarianism has developed based on the premise that private property is necessary to increase human economic welfare. Id. The former form of utilitarianism is referred to here as traditional utilitarianism, while the latter is referred to as instrumentalism.

188. See, e.g., THE Federalist, supra note 156, at 309 (noting utilitarian basis of constitutional Patent Clause). 
sell inventions) because it must do so in order to encourage innovation. ${ }^{189}$ The instrumental justification states that real work is required to innovate, and such work is unpleasant enough (at least, relative to leisure) that a rational actor would not engage in it without the expectation of some benefit. ${ }^{190}$ Thus, people should be rewarded with property to motivate them to do work. ${ }^{191}$

With respect to intellectual property, the instrumental argument contends that society rewards inventors and authors with patents and copyrights because inventors and authors must be motivated to exert themselves to create. This theory relies on four essential premises. First, inventions require labor; in other words, the "eureka" nodel of invention (that is, invention by a sudden stroke of genius) either does not apply or applies so infrequently as to justify a per se reward. ${ }^{192}$ Second, the labor of invention is unpleasant, or at least less pleasant than leisure. ${ }^{193}$ Thus, inventors will not mvent simply for the love of it; they need external mcentives. ${ }^{194}$ Third, inventions, in aggregate, improve social welfare. Thus, it is worthwhile for society to provide mcentives for inventors to suffer the unpleasantness of labor. Finally, the "public good" attribute of inventions requires intellectual property protection for inventors to appropriate value from their inventions. ${ }^{195}$

Courts and legal cominentators often rely on instrumental labor justifications for the patent system. Congressional grants of exclusive patent rights to inventors are frequently conceptualized as a quid pro quo from society to inventors (although there is far froin universal agreement as to what is the quid and what is the quo). ${ }^{196}$ The nost commonly articu-

189. See, e.g., Hughes, supra note 149, at 303-04.

190. Justice Stone's dissent in United States v. Dubilier Condenser Corp., 289 U.S. 178 (1933), describes scientists who are either irrational or from a nobler era: "It has been said that many scientists in the employ of the government regard the acceptance of patent rights leading to commercial rewards im any case as an abasement of their work." Id. at $218 \mathrm{n} .9$ (Stone, J., dissenting) (citing Hearings on Exploitation of Inventions by Government Employees Before the Senate Comm. on Patents, 65th Cong., 3d Sess. 16-17 (1919)).

191. Hughes, supra note 149, at 303 . This instrumental argunent should be distinguished from the normative argument, discussed supra Section III.B.1.b. Both arguments are based on two ideas: (1) labor is unpleasant, and (2) labor is necessary. The instrumental argument concludes that property must be used to motivate people to do unpleasant but necessary work. The normative argument, in contrast, concludes that people ought to receive property for doing unpleasant but necessary work.

192. See Hughes, supra note 149 , at 300.

193. See id. at 302.

194. But see BENNETT, supra note 20, at 31 (showing "Love of Inventing" as the most frequently mentioned motive or incentive in survey of inventors).

195. For a discussion of "public good," see supra note 147 and accompanying text.

196. One economic commentator, for example, has parodied the economic literature on patents as follows: "What does the patent system give us, and at what cost? . . Bentham claims something for nothing; Taussig responds nothing for nothing, Plant rejoins nothing for something; Arrow replies something (but not enough) for something...." George L. Priest, What Economists Can Tell Lawyers About Intellectual Property: Comment on Cheung, in 8 RES. IN L. \& ECON. 19 (John 
lated purpose of patents is to foster or stimulate invention. ${ }^{197}$ This is often the sole purpose articulated by the courts. ${ }^{198}$ Occasionally courts have noted additional instrumental purposes for the patent system, such as creating an incentive to disclose inventions. ${ }^{199}$

Economic coinmentators, too, tend to frame the purposes of the patent system in mcentive-based terms. For example, Edwin Mansfield has identified three justifications for patent laws: (1) to induce mdividual inventors to put in the work required to produce an invention; (2) to induce firms to make the investments required to bring the invention to commercial use; and (3) to induce firms to disclose inventions earlier than would otherwise be the case. ${ }^{200}$ Economic arguments, such as Mansfield's, tend to focus on the social utility of inventions and the need for inventors to appropriate rents on their creations. It sliould be noted, however, that not all econormists are convinced about the efficacy of pat-

Palmer \& Richard O. Zerbe, Jr. eds., 1986). In United States v. Dubilier Condenser Corp., 289 U.S. 178 (1933), the Supreme Court described the quid pro quo in the following terms:

An inventor deprives the public of nothing which it enjoyed before his discovery, but gives something of value to the community by adding to the sum of human knowledge. He may keep his invention secret and reap its fruits indefinitely. In consideration of its disclosure and the consequent benefit to the community, the patent is granted. An exclusive enjoyment is guaranteed him for seventeen years, but upon the expiration of that period, the knowledge of the invention enures to the people, who are thus enabled without restriction to practice it and profit by its use.

Id. at 186-87 (citations omitted).

197. See, e.g., Zacchini v. Scripps-Howard Broadcasting Co., 433 U.S. 562, 576 (1977) (stating that the desire to provide "an economic ineentive for [the inventor] to make the investment required to produce" an invention underlies the patent law); Goldstem v. California, 412 U.S. 546, 555 (1973) ("The objective [of the Copyright and Patent Clausel is to promote the progress of science and the arts. As employed, the terms 'to promote' are synonymous with the words 'to stimulate,' 'to encourage,' or 'to induce." "). This view, is, of course, consistent with the constitutional grant of authority to Congress "[t]o promote the Progress of Science and useful Arts, by securing for limited Times to Authors and Inventors the exclusive Right to their respective Writings and Discoveries." U.S. CoNST. art. I, \& 8, cl. 8.

198. See, e.g., Dawson Chem. Co. v. Rohm \& Haas Co., 448 U.S. 176, 221 (1980) ("[T]he policy of stimulating invention that underlies the entire patent system runs [deep in our law]."); Dr. Miles Medical Co. v. John D. Park \& Sons Co., 220 U.S. 373, 401 (1911) ("The purpose of the patent law is to stimulate invention ....").

199. The Court in Aronson v. Quick Point Pencil Co., 440 U.S. 247 (1979), listed the following purposes of the patent system:

First, patent law seeks to foster and reward invention; second, it promotes disclosure of inventions to stimulate further innovation and to permit the public to practice the invention once the patent expires; third, the stringent requirements for patent protection seek to assure that idcas in the public domain remain there for the free use of the public.

Id. at 262.

200. Edwin Mansfield, Intellectual Property, Technology and Economic Growth, in Intellectual Property Rights in Science, Technology, and Economic Performance: INTERNATIONAL Comparisons 17, 23 (Francis W. Rushing \& Carole G. Brown eds., 1990) [hereinafter INTERNATIONAL COMPARISONS]; see also Louis Kaplow, The Patent-Antitrust Intersection: A Reappraisal, 97 HARV. L. REV. 1813, 1823-24 (1984) (listing reward to patentee, stimulation of inventive activity, and improvement of social welfare as goals of the patent system); Yusing Ko, Note, An Economic Analysis of Biotechnology Patent Protection, 102 YALe L.J. 777, 791800 (1992) (discussing incentive to invent and incentive to disclose theories). 
ent laws in fostering invention. ${ }^{201}$

Setting aside these concerns about the efficacy of patent laws, it remains unclear how one would resolve preinvention assignment disputes based on imstrumental justifications. The resolution of these disputes would seem to depend upon the mventorship paradigm that one accepts. Adherents of the "hero-mventor" paradigm are sensitive to the need for individual incentives. ${ }^{202}$ "Team-as-hero" proponents stress the importance of providimg incentives for investment of capital in inventive activities. $^{203}$ Both arguments have merit, and there appears to be no analytic

201. See, e.g., Senate Subcomm. on Patents, Trademarks, and Copyrights, Senate COMm. ON THE JUdiciary, 85Th CONG., 2D SESS., AN ECONOMIC ReVieW of THE PATENT SYSTEM (Study No. 15, Comm. Print 1958):

No economist, on the basis of present knowledge, could possibly state with certainty that the patent system, as it now operates, confers a net benefit or a net loss upon society. The best he can do is to state assumptions and make guesses about the extent to which reality corresponds to these assumptions.

See also Ward S. Bowman, Patent and ANTtTrust LAW: A Legal and Economic APPRAISAL 15-32 (1973) (summarizing conflicting economic appraisals of the patent system); Kaplow, supra note 200, at 1833-34 ("Yet our knowledge is inadequate to inspire great confidence even in the desirability of having a patent system at all, much less in the ability to make the subtle measurements of marginal effects that determine the ratio implicit in the optimal patent lifc.'); Oddi, supra note 15, at 1101 (noting that while there is insufficient economic evidence to abolish the existing patent system, there would be insufficient economic evidence to justifying establishing a patent system in a society that did not already have one); Priest, supra note 196, at 21 ("[E]conomists know almost nothing about the effect on social welfare of the patent system or of other systems of intellectual property.").

A recent study has concluded that investors are indifferent to the knowledge that a firm's patent has been found invalid. See Page M. Kaufman, An Empirical Study of the Effect of Patent Invalidity Judgments on the Abnormal Returns of Publicly Traded Securities, 19 AM. INTELL. PRoP. L. Ass'N Q.J. 282 (1991).

202. This corresponds to Mansfield's flrst justification. See supra text accompanying note 200. For examples of commentary supporting this view, see Sutton, supra note 6, at 152-53:

The incentive for a reward as drafted in the Constitution goes to the inventor, not his sponsor, employer, banker or spouse. It is the inventor who is to be encouraged, not the investor of mere money. Money cannot buy inventions, which do not exist until created. Individual people must create them. ...

An incentive, by definition, is an inducement to action. If the employee has nothing more than a salary, which he will get whether he invents or just performs the research assigned to him, then what is the inducement to create something which is not obvious to one of ordinary skill in the art? ... Some people will create without cconomic incentives, a pat on the back being sufficient for a long time. However, economic incentive-money-is a powerful force that can induce the extraordinary creativity that produces inventions. The founding fathers recognized it and wrote the incentive concept into the Constitution. Present-day employers have neutralized this incentive by requiring all inventions to be turned over to the employer even before they are conceived.

See also Ubell, supra note 117 . Ubell notes that

the Constitution ... contemplates promoting the progress of science and the useful arts by securing to inventors for a limited time exclusive rights to their inventions. The Constitution does not suggest promoting the progress of science and the useful arts by "securing to capitalists exclusive rights to the creations of inventors."

Id. at 30 (citation omitted).

203. This corresponds to Mansfield's second justification. See supra text accompanying note 200. For examples of cominentary supporting this view, see Alden F. Abbott, Developing $a$ Framework for Intellectual Property Protection to Advance Innovation, in INTERNATIONAL COMPARISONS, supra note 200, at 311, 320-21: 
basis upon which to favor one view over the other. It is possible to argue that the purposes of the patent system are best furthered by providing incentives for mdividuals to mvent or by providing incentives for firms to invest in mvention.

One commentator, Professor Jay Dratler, has proposed recognizing the need for incentives for both einployee-inventors and their employers by dividing ownership of patent rights between individuals and firms according to the relative extent of "extraordinary effort" each has contributed towards the invention. ${ }^{204}$ Because the relationship between patent incentives and inventive output is difficult to demonstrate, ${ }^{205}$ however, it is difficult to imagine how instrumental arguinents can be used to divide the patent incentive between employers and employee-imventors. Additionally, as Dratler himself has persuasively argued, incentives do not act on an undifferentiated corporate entity but rather upon individuals within the corporate structure. ${ }^{206}$ When the roles of individuals other than inventors within firms are examined, patents may not provide real incentives to innovate. ${ }^{207}$

[R]isk-averse firms will be reluctant to hire research staffs and establish research facilities if there is no assurance that profits can be earned on that small portion of innovative projects. Intellectual property protection provides that necessary assurance. Without such protection firms would run the risk that, because of frec-riding, their innovations would earn insufficient profits to offset the losses stemming from failed research efforts. For the same reason, capital markets would be far less wilhng to provide funds for independent research efforts in a world without intellectual property protection. In short, without intellectual property protection, talented scientists and engineers would find it much harder to obtaim the backing needed to explore new avenues of research, and innovation would proceed at a far slower pace to the detriment of society.

See also BowmaN, supra note 201, at 23-28 (summarizing arguments, principally those of Arrow, that markets tend to under-reward invention, and that patent protection is thus needed to correct for this market failure). Commentators adopting this view tend to downplay the role of individuals. See, e.g., Zuber, supra note 6, at 146, 148:

Let us look for a moment at the effects of patent policy on the inventor, the repository of the creativity that we are discussing. . . . There is an increased tendency to assert individual rights to ideas which may properly be ascribed to a group effort. ...

....

In speaking of recoguition, direct monetary awards to inventors needs mentioning. Proponents of this type of reward believe that creativity would be fostered. Direct monetary rewards certainly could be part of any patent policy, but, personally, I have great difficulty with this concept stemming from the fact that projects are assigned and are not selected by those doing the research. The truly creative people are a precious few. Good management is apt to reserve them for projects where immediate results are required. I have known cases where scientists of little more than average ability have made inventions of considerable economic importance because management could afford to assign them to long-term projects. Providing high rewards for such efforts is akin to a lottery. Such rewards are not apt to foster a climate in which individuals feel rewards stem from excellence rather than from the luck of the draw. Consequently, I have very deep and profound doubts that direct monetary awards are apt to make a positive contribution to a creative environment.

204. See Dratler, supra note 6. Actually, this is really a normative labor argument rather than an instrumental one. It is mentioned here, however, because Dratler frames his argument in instrnmental terms.

205. See supra note 201 and accompanying text.

206. Dratler, supra note 6 , at 173.

207. Id. at 172-75. Corporate technical workplaces, like most workplaces, are hierarchical 
One might argue that it does not matter whether the employee-inventor or employer receives the initial patent entitlement because the parties will distribute it between themselves by private agreement so as to maximize inventive productivity. ${ }^{208}$ This argument is flawed on several grounds. First, it assumes that transaction costs are zero. As discussed earlier, however, transaction costs are particularly lighl in the preinvention context because of the difficulties of ex ante bargaining for speculative rights, and those of ex post bargaining where tlie contributions of the parties are liard to quantify objectively. ${ }^{209}$ Second, this claim assumes a functioning market for employee-inventors. In fact, the market for technical employees is susceptible to contracts of adlesion. ${ }^{210}$ Finally, the argument assumes that firms and society value inventions sinilarly. In reality, a given invention may be of little value to a particular firm but of great value to society generally (or vice versa).

Instrumental labor arguments, then, are not useful in resolving preinvention assignment conflicts. Even if incentives are required to get inventor-entities to invent, it is inipossible to determine ex ante which component of the inventor-entity-employee-imventor or employer-requires that incentive. Moreover, even if ex post determinations can be niade to allocate intellectual property riglits to the employee-inventor or einployer based upon relative contribution or otler criteria, sucli determinations, strictly speaking, are normative rather tlian instrumental in approach. Furtliermore, any incentive effect of an ex post reward would be severely attenuated due to tlie extremely speculative nature of the reward: the likelihood of successful invention is speculative, the likeliliood of a patent award upon success is speculative, ${ }^{211}$ and the likeliliood of a property interest in the patent if awarded is speculative since the relative contributions of the parties cannot be determined ex ante.

environments: technicians report to engineers, who report to project leaders, who report to managers, and so on. Each has different priorities. The support of an engineering manager may be critical to an invention's success (such as in assigning resources) but may not rise to the level recognized by the patent law for "reward." In fact, the manager understandably may have a disincentive for the engineer to invent (and expend time and resources) when the invention is unrelated to an area for which the manager has responsibility or in which the corporation has a bona fide business interest. Yet the invention may be very valuable to society. The point is that there is an agency cost associated with allowing corporations to provide their own incentive structures for inventors in place of those provided by the patent law. That is, there is at least a potential divergence between the interests of society and those of corporations in the fostering of inventions.

208. This argument is based on a variation of the Coase Theorem. See Ronald H. Coase, The Problem of Social Cost, 3 J.L. \& ECON. 1 (1960).

209. See supra notes $\mathbf{1 2 5 - 2 6}$ and accompanying text for discussion of the difficulties of ex ante and ex post bargaining.

210. See supra notes 113-17 and accompanying text for discussion of adhesion contracts.

211. The invention may be deemed non-novel, obvious, or anticipated by the Patent Office. 


\section{The Failure of Traditional Theories}

None of the natural law and utilitarian theories discussed in this Comment is appropriate for resolving premvention assignment disputes because none adequately distinguishes between the einployee-inventor and employer. Similarly, other justifications that have been used for private property generally and for patents in particular ${ }^{212}$ provide little guidance in resolving preinvention assigninent disputes. Given this failure of traditional theories, it is not surprising that employee-inventors and einployers have been unable to arrive at a contractual agreeinent that is satisfactory to both parties. Perhaps, then, it is time to go beyond the traditional theories in search of a resolution for preinvention assignment disputes.

\section{IV}

\section{Personhood and the Employee-INVENTor: AN ALTERNATIVE FRAMEWORK FOR THE Resolution of Preinvention ASSIGNMENT DISPUTES}

Part II explained that the prohferation of premvention assignment agreements was partly a response by corporations to changes in inventorship paradigms that were not reflected in the patent law conception of inventorship. Although these agreements present numerous contractual difficulties, they are generally enforced by the courts, perhaps in recognition of the deficiencies in patent law.

Part III responded to the limitations of contract and patent doctrine by applying traditional property justifications to the allocation of property rights in preinventions. These traditional justifications were found inadequate for resolving preinvention assigument disputes. However, the full range of theoretical property justifications was not exhausted in Part III. This Part of the Comment will examine an alternative theoretical property framework: personhood theory.

212. Professor Kitch, for example, has proposed a "prospect" theory of patents, analogizing the patent system to the property system protecting mineral rights. Kitch posits that patents essentially grant exclusive rights to develop a prospect-the prospect of future inventions. See Edmund W. Kitch, The Nature and Function of the Patent System, 20 J.L. \& EcoN. 265, 266 (1977) (first proposing the prospect theory). But see Roger L. Beck, The Prospect Theory of the Patent System and Unproductive Competition, in 5 REs. IN L. \& EcON. 193, 199-206 (Richard O. Zerbe, Jr., ed., 1983) (arguing that empirical evidence undermines the prospect theory). Grady and Alexander have proposed a rent dissipation theory of patents whereby patents are rewarded to maximize the difference between the value of an invention to society and its development cost by discouraging copying and redundant development costs and preserving such rents for successful inventors. Mark F. Grady \& Jay I. Alexander, Patent Law and Rent Dissipation, 78 VA. L. Rev. 305, 316-21 (1992). Neither the prospect theory nor the rent dissipation theory adequately accounts for the firm/ employee dichotomy of the inventor-entity. 


\section{A. Personhood Theories of Property}

The personhood theory of property focuses on the relationship between property and personality. Property, it is argued, is justified because it is conducive, perhaps necessary, to the development of personality. Personality has many meanings. For example, personality can refer to "moral and political personhood,"213 "awareness of individuatimg cliaracteristics," 114 or "the desirable integration of the self's thouglits and attitudes."215 Every meaning of personality contains some notion of the person as an autonomous, moral, individuated agent. Although different formulations of personlood theory emphasize different meanings of personality, elements of each of these meanings are always present.

Personhood theory has been characterized here as an alternative theory of property im the sense that the analysis is, to some extent, outside the mainstream of judicial, if not philosophic, thought. However, personhood theories of property are by no means new. Elements of a personhood theory of property are evident in the work of Plato and Aristotle, ${ }^{216}$ although personhood theory as we understand it today was first limted at in the work of Kant in the eighteenth century. ${ }^{217}$ Kant, lowever, was working within a natural rights framework, ${ }^{218}$ and thus Kantian personhood is really more a variant of traditional property theory thian an alternative theory. ${ }^{219}$

213. MUNZER, supra note 34 , at 81.

214. Id. at 82.

215. Id. at 84 .

216. See id. at 125-29.

217. See RYAN, supra note 153, at 73-90 (discussing Kant and personhood theory). Personhood theory today places property that is constitutive of personality outside the market. This is perhaps first alluded to in a oft-quoted passage by Kant:

In the kingdom of ends everything has either a price or a dignity. If it has a price, something else can be put in its place as an equivalent; if it is exalted above all priee and so admits of no equivalent, then it has a dignity.

$\ldots$

... [M]orality, and humanity so far as it is capable of morality, is the only thing which has dignity.

IMMANUEl Kant, Groundwork of THe Metaphysic of Morals 102 (H.J. Paton trans., 1964).

218. See STEVen B. SMITH, Hegel's CRITIQUe of L1BERALISM 70-80 (1989).

219. Another 18th-century natural-rights-based property justification with elements of personhood is the concept of artists' moral rights. See generally DRATLER, supra note 25, § 6.01[6]; Karen M. Corr, Comment, Protection of Art Work Through Artists' Rights: An Analysis of State Law and Proposal for Change, 38 AM. U. L. Rev. 855 (1989); Craig A. Wagner, Comment, Motion Picture Colorization, Authenticity, and the Elusive Moral Right, 64 N.Y.U. L. REv. 628 (1989). The moral rights of artists and authors have been especially important in French jurisprudence, where rights in works of art and literature have been divided into economic rights (droits patrimoniaux) and creative rights (droit moral). Corr, supra, at 863; Wagner, supra, at 687. The concept of personal, inalienable, moral rights of artists has much in common with the personhood interests of inventors discussed in this Comment. Personhood, as described here, however, seeks to protect different interests and is based on a different philosophic foundation than moral rights. 


\section{Hegelian Personhood}

An alternative philosophy of property and its relationship to personality independent of natural rights or utilitarian justifications was developed by Hegel in the early nineteenth century, based on his conceptions of will, freedom, and personhood. ${ }^{220}$ Hegel beheved that each person has both an internal and an external existence. ${ }^{221}$ One's internal existence is her will, and one's external existence is her sphere of freedom. ${ }^{222}$ Hegel stressed the importance of self-actualization, or the lack of dependence on an other. ${ }^{223}$ However, self-actualization and the extension of one's sphere of freedoin are achieved, in Hegel's view, not by withdrawing from the external world but rather by "overcoming it,"224 or putting one's will into external objects-into property.

For Hegel, freedom meant relating to external objects so that they become integrated into one's personality. Personality is the reconciliation of the inner self and external world. ${ }^{225}$ Property-the relationship between persons and things ${ }^{226}$-is the ineans by which we achieve this reconciliation. Property, then, is central to Hegel's theory of the fully

220. G.W.F. Hegel, Elements of The Philosophy of Right (Allen W. Wood ed. \& H.B. Nisbet trans, 1991). The editor of this edition cautions that "Hegel is cited much more frequently than he is read, and discussed far oftener than he is understood." Id. at xxvii. I have quoted liberally from Hegel in these notes so as to address the former concern, if not the latter.

221. "As the immediate concept and hence also [asl essentially individual, a person has a natural existence [Existenz] partly within himself and partly as something to which he relates as to an external world." Id. $\S 43$ (alterations in translation).

222. The person must give himself an external sphere of freedom in order to have being as Idea. The person is the infinite will, the will which has being in and for itself, in this first and as yet wholly abstract determination. Consequently, this sphere distinct from the will, which may constitute the sphere of its freedom, is likewise determined as immediately different and separable from it.

Id. $\S 41$.

223. "Only in this freedom is the will completely with itself [bei sich], because it has reference to nothing but itself, so that every relationship of dependence on something other than itself is thereby eliminated." Id. $\S 23$ (alteration in translation).

The universality of this will which is free for itself is formal universality, i.e. the will's selfconscious (but otherwise contentless) and simple reference to itself in its individuality [Einzelheit]; to this extent, the subject is a person. It is inherent in personality that, as this person, I am completely determined in all respects (in my inner arbitrary will, drive, and desire, as well as in relation to my immediate external existence [Dasein]), and that I am finite, yet totally pure self-reference, and thus know myself in my finitude as infinite, universal, and free.

Id. $\S 35$ (alteration in translation).

224. G.W.F. Hegel, Hegel's Philosophy of MIND $\S 382$ (William Wallace \& A.V. Miller trans., 1971).

225. See supra notes $221,223$.

226. To have even external power over something constitutes possession, just as the particular circumstance that I make something my own out of natural need, drive, and arbitrary will is the particular interest of possession. But the circumstance that $I$, as free will, am an object [gegenständlich] to myself in what I possess and only become an actual will by this means constitutes the genuine and rightful element in possession, the determination of property.

HEGEL, supra note $220, \S 45$ (alteration in translation). 
self-actualized free person; it is the essence of personality. ${ }^{227}$

The rules of Hegelian property law flow directly from the Hegelian conception of property. To make a thing one's property, one must be the first $^{228}$ to take actual possession ${ }^{229}$ of the thing, or the first to mark the thing as one's own. ${ }^{230}$ Property, in the form of ordinary external things, is alienable, ${ }^{231}$ but property wlich forms an essential element of personality must be inalienable. ${ }^{232}$

\section{Radinian Personhood}

In recent years, Professor Margaret Radin has used an essentially Hegelian framework to extensively examine tlie relationslip between property and personhood. ${ }^{233}$ Property riglits exist, Radin argues, be-

227. Or, in Hegel's terms, the "existence" [Dasein] of personality. See id. $\$ 51$ ("property ... is the existence [Dasein] of personality") (alteration in translation); $i d$. $\S 50$ ("personality must have existence [Dasein] in property.") (alteration in translation). This concept has also been translated as saying that "property is the embodiment of personality." G.W.F. HEGEL, HEGEL's PHILOSOPHY OF Right $\S 51$ (T.M. Knox trans., 1952) (alteration in translation).

228. That a thing [Sache] belongs to the person who happens to be the first to take possession of it is an immediately self-evident and superfluous determination, because a second party cannot take possession of what is already the property of someone else.

$\ldots$ The first is not the rightful owner because he is the first, but because he is a free will, for it is only the fact that another comes after him which makes him the first.

HEGEL, supra note $220, \S 50$ (alteration in translation).

229. "My inner idea [Vorstellung] and will that something should be mine is not enough to constitute property ... on the contrary, this requires that I should take possession of it. The existence which my willing thereby attains includes its ability to be recognized by others." Id. $\S 51$ (alteration in translation).

230. That mode of taking possession which is not actual in itself but merely represents my will occurs when I mark a thing [Sache] with a sign to indicate that I have placed my will in it ....

Taking possession by designation is the most complete mode of all ... . If I seize a thing or give form to it, the ultimate significance is likewise a sign, a sign given to others in order to exclude them and to show that $I$ have placed my will in the thing.

Id. $\S 58$ (alteration in translation).

231. It is possible for me to alienate my property, for it is mine only in so far as I embody my will in it. Thus, I may abandon (derelinquiere) as ownerless anything belonging to me or make it over to the will of someone else as his possession-but only in so far as the thing [Sache] is external in nature.

Id. $\$ 65$ (alteration in translation).

232. "Those goods, or rather substantial determinations, which constitute iny own distinct personality and the umiversal essence of my self-consciousness are therefore inalienable, and my right to them is imprescriptible. They include my personality in general, my universal freedoin of will, ethical life, and religion." Id. $\S 66$.

233. See Margaret J. Radin, The Liberal Conception of Property: Cross Currents in the Jurisprudence of Takings, 88 ColuM. L. REV. 1667 (1988); Margaret J. Radin, MarketInalienability, 100 HARV. L. REV. 1849 (1987) [hereinafter Radin, Market-Inalienability]; Margaret J. Radin, Property and Personhood, 34 STAN. L. REv. 957 (1982) [hereinafter Radin, Property and Personhood]; Margaret J. Radin, Residential Rent Control, 15 PHIL. \& PUB. AFF, 350 (1986) [hereinafter Radin, Residential Rent Control]. It should be noted that personhood has been investigated as a basis for the Lockean labor justification of property as well. See BECKER, supra note 167, at 48-49. Coinpare the Hegelian justifieation (set forth supra Section IV.A.1), the Radinian justification (set forth infra notes $234-47$ and accoinpanying text), and Becker's proposed (but ultimately rejected) explanation for a labor justification of property (set forth here):

[L]abor is (in some circumstances) psychological appropriation-appropriation in the sense 
cause people achieve self-identification (that is, they define their "selves" as people) through external objects. ${ }^{234}$ Certain objects become "bound up with personhood"235 because of the way we use those objects to define ourselves as people. Unlike inore traditional theories which focus on the creation of the property, the personhood theory looks to the "subjective relationship between the holder and the thing."236 Radin uses a wedding ring, a portrait, an heirloom, and a hoine ${ }^{237}$ as examples of objects which may be bound up with personhood for particular individuals. ${ }^{238}$ An indiciun of a personality interest in property is a value to its owner that exceeds market value. ${ }^{239}$

At the opposite end of the property spectruin froin personhood property ${ }^{240}$ is fungible property: $:^{241}$

Property that is "personal" in this philosophical sense is bound up with one's personhood, and is distinguishable from property that is held inerely instrumentally or for investinent and exchange and is therefore purely commercial or "fungible." One way to look at this distimction is to say that fungible property is fully commodified, or represents the ideal of the commodity form, whereas personal property is at least partially noncommodified. ${ }^{242}$

By definition, the value of fungible property to its owner is its inarket value. Noncommodifiable property, by contrast, is property that is removed froin the marketplace and is nonsalable. ${ }^{243}$ A fungible property market regine can be useful because it allows dissinilar property rights to be commensurable. Radin theorizes, however, that certain property rights are incommensurable. Property rights at the fungible end of the spectrum may be overridden, while property rights at the personhood

of a "felt incorporation" of the thing labored on 'into' one's person. If it is true than I 'am' (psychologically) what I want to become as well as what I have become, then one can say with similar validity that I am what I have made. I am what I was, what I do, what I want to do, and what I produce. These are all greatly abbreviated locutions for complex facts about personality ....

BECKER, supra note 167 , at 49.

234. Radin, Property and Personhood, supra note 233, at 959-61.

235. Id. at 959 .

236. Id. at 987.

237. For judicial support of Radin's theory of a personhood interest in one's home, see Silverman v. Barry, 845 F.2d 1072, 1081 (D.C. Cir.) (noting that "[t] $]$ he law has long shown a special solicitude for the interest of a person in being secure in his or her hoine" (citing Radin, Property and Personhood, supra note 233), cert. denied, 488 U.S. 956 (1988).

238. Radin, Property and Personhood, supra note 233, at 959.

239. Id. at $959-60$.

240. This is an awkward linguistic construct, but the obvious alternative, "personal property," carries too much legal baggage to use in this context.

241. Radin, Property and Personhood, supra note 233, at 960.

242. Radin, Residential Rent Control, supra note 233, at 362.

243. "When something is noncommodifiable, market trading is a disallowed form of social organization and allocation. We place that thing beyond supply and demand pricing, brokerage and arbitrage, advertising and marketing, stockpiling, speculation, and valuation in terms of the opportunity cost of production." Radin, Market-Inalienability, supra note 233, at 1855. 
end of the spectrum may not. Thus, Radim suggests, "The more closely connected with personhood, the stronger the entitlement."244

Radim does not propose that all property be malienable and noncommodifiable. Rather, she stakes out a pluralist position somewhere on the broad contimuum between Karl Marx and Richard Posner ${ }^{245}$ which she calls "market-malienability," where some property is fully commodified, some is noncommodified, and some is partially or incompletely commodified. ${ }^{246}$ Incomplete commodification is designed to solve problems of "contested commodification"-property issues where there is active debate over the wisdom of either fully alienable or fully inalienable regimes. Radin identifies infants and children, fetal gestational services, blood, human organs, sexual services, and the services of college athletes as examples of contested commodification. ${ }^{247}$ Employee preinventions, it will be demonstrated, also represent a problem of contested commodification.

\section{Personhood and Inventorship}

If pork bellies are fungible and weddimg rings are personal, where do patent rights belong? Courts have recognized the peculiarly personal nature of patent rights:

The reluctance of courts to imply or infer an agreement by the employee to assign his patent is due to a recognition of the pecuhar nature of the act of invention .... It is the result of an mventive act, the birth of an idea and its reduction to practice; the product of orignial thought . . . .248

Commentators, too, have recognized the personality element of intellectual property. ${ }^{249}$ The identification of an inventor with her creation is similar to that of the writer or the painter with her creation. ${ }^{250}$ Personality in these latter forms of intellectual property has long been recognized. ${ }^{251}$ This Section will show that inventors have significant personality stakes in their imventions as well.

244. Radin, Property and Personhood, supra note 233, at 986.

245. Radin, Market-Inalienability, supra note 233, at 1857.

246. Id. at 1955.

247. Id. at 1856.

248. United States v. Dubilier Condenser Corp., 289 U.S. 178, 188 (1933).

249. For example, in tracing the history of patents, William Kingston remarks that the "[1] egal protection of disembodied information thenceforward reflected the view that the work of writers and inventors is an extension of their personalities, and consequently in some sense, 'theirs." " KiNGSTON, supra note 147, at 104.

250. See Brown, supra note 42, at 236 (interviewing inventor Steven Wozniak: "I recognized that with every little key I had hit upon, I had done something in so few parts that it was outstanding in an artistic sense. To me, an artistic design meant very few components doing the maximum job.").

251. See, e.g., Bleistein v. Donaldson Lithographing Co., 188 U.S. 239, 250 (1903) (Holmes, J.) ("The copy [a lithograph] is the personal reaction of an individual upon nature. Personality always contains something unique. ... That something he may copyright ...."). For a psychological 
According to Radin, the identification of an eleinent of personality in property is inerely the first step in determining whether that property ought to be treated as legally personal. The next step is to determine if the personal identification is "justifiable." Radin beheves that personthing relationships that facilitate an individual's understanding of "freedoin, identity, and contextuality"252 are justifiable personhood interests because they contribute to "our conception of human flourishing."253 There is no formula for determining if a particular property interest is justifiably personal. We are left to "rely instead on our best inoral judgment in hight of the best conception of personhood as we now understand it."254

Work is an example of mcoinplete commodification. We expect nonmonetary returns from our work, even though we demand payment in return for our services. ${ }^{255}$ A person's relationship with her work facilitates an understanding of the three elements mentioned above that contribute to human flourishing: freedom, identity, and contextuality. ${ }^{256}$ Preinventions are reified inventive work which imphicate each of these three eleinents. "Freedom" refers to the autonomy aspect of personhood, the ability "to act for ourselves through free will in relation to

examination of the relationship between art and artist, see generally OTTO RANK, ART AND ARTIST: Creative Urge and Personality Development (Charles F. Atkinson trans., 1932).

252. Radin, Market-Inalienability, supra note 233, at 1908 . These terms are defined infra text accompanying notes 257,258 , and 259 , respectively.

253. Radin, Market-Inalienability, supra note 233, at 1908.

254. Id. at 1909. Although Professor Radin does not address the question of whether inventions represent justifiable personal property, her treatment of a person's identification with her work as a justifiable personhood interest provides a useful insight:

The view that personhood is involved with continuity of context need not be limited to the property or object relations [heirlooms, wedding rings, homes, and so on] I am discussing here. It could generate other categories of human interactions where continuity is involved with personhood, perhaps most notably in connection with work and the workplace.

Radin, Residential Rent Control, supra note 233, at 363.

255. See Radin, Market-Inalienability, supra note 233 , at 1918 . Highly routinized work will tend to be more commodified than creative work because it is reasonable to expect greater nonmonetary returns from the latter than the former. Work is partially decommodified through such mechanisms as minimum wage requirements, health and safety requirements, and antidiscrimination requirements. Id. at 1919. Consider the following description of work on an automobile assembly line, work that is highly commodified (though highly regulated):

[T] he only meaning of the job is in the pay check, not in anything connected with the work or the product. Work appears as something unnatural, a disagreeable, meaningless and stultifying condition of getting the pay check, devoid of dignity as well as of importance. . . . No wonder that this results in an unhappy and discontented workerbecause a pay check is not enough to base one's self-respect on.

Peter F. DRuCKer, CONCEPT OF THE CORPoration 179 (1946). On the other hand, Professor Williamson would reject the notion that highly commodified work is an "inferior" form of employment since some workers will actually prefer such jobs. See Williamson, supra note 84, at 268-69 (asserting that automobile assembly workers, for example, choose highly commodified work because they voluntarily sacrifice work satisfaction for greater pay). Professor Williamson acknowledges, however, that "capitalism is prone to undervalue dignity and that institutional safeguards can sometimes be forged that help to correct the condition." Id. at 271.

256. Radin, Market-Inalienability, supra note 233, at 1920. 
the environment of things and other people."257 "Identity" refers to individuation, which requires "the integrity and continuity of the self over time."258 Autonoiny and individuation are, as mentioned earlier, common elements of any definition of personhood. "Contextuality," as that term is used by Professor Radin, combimes eleinents of both autonomy and individuation. Contextuality refers to the development and constitution of the self through "relationships with the social and natural world."259

An inventor's autonouny over her own inventiveness is diminished when another entity, her employer, holds the exclusive right to make, use, or sell her creative output. Some degree of control over one's own inventions is required to make possible, and protect, the constituting of autonomous personhood in mventive work. ${ }^{260}$ An inventor's individuation is threatened when an employer can preclude an inventor from contimuing to work with her creation even after she leaves the employment relationship. Some degree of inventive continuity is required to make possible, and protect, the constituting of individuating personhood in inventive work. ${ }^{261}$ An inventor's self-development and self-conception through contextuality are impaired when her relationship with her inventions-her work - is determined not by her, but by her employer, ${ }^{262}$ and when her work is monetized, alienated, and detached from her self ${ }^{263}$ and from the "particulars" integral to her self. ${ }^{264}$ Thus Professor Radin's personhood theory can provide useful insights for resolving preinvention assigninent disputes.

One might ask why inventors should receive special treatment under personhood theory that other laborers do not enjoy. For example, as Professor James Boyle has noted in a somewhat different context, "We do not think it is necessary to give car workers residual property rights in the cars that they produce-wage labor is thought to work perfectly well."265 The rebuttal, of course, is that the important distinction is not between "car workers" and inventors, but rather between the making of

257. Id. at 1904.

258. Id.

259. Id. "[C]ontextuality implies that self-development in accordance with one's own will requires one to will certain interactions with the physical and social context becausc context can be integral to self-development." Id. at 1905.

260. See id. at 1920 (equating control over work with the freedom aspect of pcrsonhood).

261. See id. (equating continuity of work with the identity aspect of personhood).

262. See id. (equating "self-conception inseparable from one's work" with the contextuality aspect of personhood).

263. See id. at 1905-06.

264. Among the "particulars" integral to the self are "politics, work, religion, family, lovc, sexuality, friendship, altruism, experiences, wisdom, moral commitments, character, and personal attributes." Id. at 1906.

265. James Boyle, $A$ Theory of Law and Information: Copyright, Spleens, Blackmail, and Insider Trading, 80 CALIF. L. REv. 1416, 1463 (1992) (questioning the special status of authorship generally). 
cars and the making of inventions. Cars are assembled according to precise specifications by the repetitious performance of assigned tasks. Inventions are "the fugitive fermentation of an individual brain."266 It is justifiable and consistent with our notions of human flourishing for an inventor to embody her personahity im her invention (or at least in certain of her inventions), even when she receives wages in return for her efforts. It is not justifiable for an autoworker to embody her personality in any one of the many identical autoinobiles upon which she labors. ${ }^{267}$

The notion that patent rights are bound up with personhood is a familiar one to patent law. For example, under the Patent Code, applications must be made by human inventors, not their corporate assignees. ${ }^{268}$ Furthermore, the apphication must mclude an oatlı by the human imventor. ${ }^{269}$ Similarly, the remedies available in patent disputes indicate that the law views patents as a form of property imbued with a strong element of personality. In disputes over fungible property, damages are considered an adequate remedy; in patent disputes, however, equitable relief is the norm. ${ }^{270}$ More to the point, contracts for the assignment of patent rights are specifically enforceable, even though traditionally only contracts with strong personality elements have been specifically enforceable. ${ }^{271}$

266. Letter from Thomas Jefferson to Isaac McPherson, supra note 166, at 334.

267. See Drucker, supra note 255, at 179 (noting the lack of personhood associated with the product of an autoworker).

268. 35 U.S.C. $\S 111$ (1988). For exceptions to this rule, see id. $\S \S 117-118$ (dealing with the death or incapacity of an inventor or her refusal to assign).

269. Id. § 115 .

270. For example, although damages are by no means unheard of, injunctive relief is virtually automatic upon a finding of patent infringement. Injunctive relief is authorized by 35 U.S.C. $§ 283$ (1988). Once final judgment has been entered as to validity and infringement, the general rule is that an injunction will issue, absent a sufficient reason for denying it. See Richardson v. Suzuki Motor Co., 868 F.2d 1226, 1247 (Fed. Cir.), cert. denied, 493 U.S. 853 (1989); see also PAul GoldSTEIN, Copyright, Patent, Trademark and Related State Doctrines 503 (3d ed. 1990) ("Courts will grant a prevailing patent owner an injunction for the remainder of the patent's life almost as a matter of course . . . "). The injunctive remedy is thought to be required in order to achieve the goals sought by the patent system. See, e.g., Smith Int'l, Inc. v. Hughes Tool Co., 718 F.2d 1573, 1578, (Fed. Cir.) (noting that "[w]ithout the right to obtain an injunction, the right to exclude granted to the patentee would have only a fraction of the value it was intended to have, and would no longer be as great an incentive to engage in the toils of scientific and technological research."), cert. denied 464 U.S. 996 (1983).

271. Comment 2 to U.C.C. \& 2-716 speaks of contracts for the sale of "heirlooms or priceless works of art" as those which have been specifically enforced, though the comment goes on to state that "uniqueness is not the sole basis" of remedy under the section. U.C.C. $\$ 2-716 \mathrm{cmt}$. 2 (1990). The examples sound remarkably like those Radin says exemplify personhood property. Professor Dan-Cohen has noted the relationship between personhood property and specific enforcement:

The view that "property is but the periphery of my person extended to things" endows our property (or in any event, some parts of it) with the special worth that calls for specific enforcement. This, of course, does not deny our right to alienate our property for a price, if we so choose. But as long as we have not freely elected to do so, our property (or whatever part of it that is thought to fit the perspective under consideration) remains infused with our will and bound up, through it, with our moral personality. As such, it should not be forcefully priced away from us. 
It should be noted that at least one commentator, Justin Hughes, has cautioned against the application of personhood theory to inventions. ${ }^{272}$ Hughes articulates three specific concerns. First, it is difficult to determine reliable indicia of who does and does not have a personality stake in any particular invention. ${ }^{273}$ Second, personality will be manifested to different degrees in particular inventions, and it is unclear whether different levels of personality call for different levels of protection. ${ }^{274}$ Finally, different categories of inventions einbody different levels of personality, which may (or inay not) justify different levels of protection. ${ }^{275}$ When each of these concerns is examined in terms of preinventions, however, none appears particularly problematic. ${ }^{276}$

Patent law has a distinct advantage over many other forms of property law when identifying reliable indicia of personality: the inventorentity inust be identified on the patent application. The inventor as defined by current patent law is an underinclusive indicium of personality, however, because otlier entities, such as an assistant, may also have a personality stake in an invention. ${ }^{277}$ This situation is a criticism of personality theory generally, however, rather than as applied to intellectual property. After all, any indiciuin of a personahity stake in property can be underinclusive. For example, a inother inay have a personality stake in her child's rental apartment if she visits regularly. The law recognizes the renter's interest, ${ }^{278}$ just as the law should recognize the inventor's interest. In both cases, the indicia of personality (sucl as having one's name on the rental agreeinent or patent application, respectively) are rehable. The law generally does not recognize the inother's or the assis-

DAN-Cohen, supra note 55, at 97 (quoting RudolPh von JHERIng, The Struggle for LAw 59 (1915)).

272. Hughes, supra note 149, at 339-54. Hughes notes that "[p]oems, stories, novels, and musical works are clearly receptacles for personality"; in contrast, Hughes argues that patents are not thought of "as manifesting the personality of an individual, but rather as manifesting a raw, almost generic insight." Id. at 340-41.

273. See id. at 339.

274. See id. at 339-44.

275. See id. at $339,344-50$.

276. It should be noted as a threshold matter that personhood will ultimately be used in this Comment not as a justification for patent rights, but, to the contrary, as a trump of patent rights, as the basis of a defense to patent infringement. See infra Sections IV.C.3.b-c. Nevertheless, it is useful to examine Hughes' objeetions to personhood theory as a justification for patent protection, as these objections are relevant to the discussion that follows. See, e.g., infra Section IV.C.1. (discussing nonappropriability of invention rights); infra Seetion IV.C.2. (discussing a cancelling or balancing approach to invention rights).

277. See, e.g., BuRLINGAME, supra note 41, at 6 (noting that "[inventor-heroesl had valuable assistants who, sometimes, were greater inventors than they").

278. For a discussion of personhood interests in rental housing, see generally Radin, MarketInalienability, supra note 233, at 1918-21; Radin, Residential Rent Control, supra note 233. For a criticism of the view that personhood interests in rental property should be recognized, see Timothy J. Brennan, Rights, Market Failure, and Rent Control: A Comment on Radin, 17 PHIL. \& PuB. AfF. 66 (1988). 
tant's personality stakes because those indicia are less reliable. ${ }^{279}$

As to Hughes' second objection, different inventions will indeed have different levels of personality invested in thein, but this need not be reflected by different levels of protection under an intellectual property regiine. Indeed, under current patent law, inventions that are inore useful or that require inore labor or inore investinent to create do not receive more protection. All inventions are treated alike once they ineet the statutory thresholds of utility, novelty, and non-obviousness. ${ }^{280}$

Hughes' last objection, in essence, asserts that inventions are simply not the repository for personality as are other forms of intellectual property, such as hiterature and inusic. ${ }^{281}$ Few would dispute that Edison's light bulb expresses a lower quantuin of personality than Tolstoy's Anna Karenina, and it is certainly the rare patent application that expresses the personality evident in an e.e. cummings poein. But this is not a valid comparison. First, inventions do reflect the personality of their inventor. The personality inay not be apparent to those without expertise in the art, but practitioners can often identify the source of an invention inerely by exainining the engineering designs. ${ }^{282}$ Engineers do not design by rote; some design decisions are inade just because they "feel" right to the designer. Second, the inventor's personality is reflected in the process that led to the invention as inuch as in the invention itself. ${ }^{283}$ Third and most importantly, the personality stake that should be protected is the extent to which botl the process and the physical einbodinent of the invention are constitutive of the inventor's personhood. ${ }^{284}$ Thus, the important issue is how the inventor defines lierself, not how society defines the inventor. ${ }^{285}$ This need not be a wholly subjective test. As discussed

279. Reliable indicia identify those personhood interests most likely to be essential to freedom, identity, and contextuality; less reliable indicia are likely to identify nonessential (though potentially justifiably constitutive) interests. Professor Radin's market-inalienability approach adopts the pluralist approach referred to earlier, see supra text accompanying note 245 , by recognizing only the reliable indicia.

280. But see Oddi, supra note 15 (proposing greater patent protection for "revolutionary" inventions).

281. See supra note 272.

282. A particularly striking example can be found in Edward J. Pershey, Drawing as a Means to Inventing: Edison and the Invention of the Phonograph, in WoRXING AT INVENTING, supra note 41, at 101 (showing some of Edison's Matisse-like engineering line drawings and discussing the relationship between the drawings, the creative process of invention, and the invention itself).

283. See, e.g., id.

284. For examples of how the inventive process can be constitutive of personhood, see VAUGHAN, supra note 74, at 4 (" "[T]he biographies of inventors give abundant illustrations of the state of inward happiness which comes from the exercise of the contriving bent.'") (quoting FrANK W. TAussig, InVENTORS AND MONEY-Makers 15 (1930)). See also BenNeTt, supra note 20, at 26 (paraphrasing Thorstein Veblen: inventors create as a means of self-expression).

285. Hughes approaches this point but, I think, misses it. He does note the popular identification of the inventor with the invention-Edison with the light bulb and Bell with the telephone-but fails to elaborate on the internal identification of inventor with invention. See Hughes, supra note 149, at 344 . This popular identification is, in fact, an inalienable interest. The 
above, reliable indicia can be established so tliat only reasonable, objectively justifiable personhood interests are protected.

A central premise of this Coinment is that inventors liave a strong personhood stake in tlieir inventions and in the inventive process, or in the terminology used lere, in inventions and preinventions. However, the identification of a personhood interest does not necessitate a rule of total inalienability for inventions and preinventions. ${ }^{286}$ Furtliermore, a given rule of market inalienability need not apply to botli inventions and preinventions, nor for that matter to all inventions or all preinventions. Rather, I propose liere to protect certain personliood interests only in einployee preinventions. ${ }^{287}$

I distinguish employee preinventions from other inventions and preinventions because tlie employee-inventor's "decision" to alienate her preinventions" is particularly suspect. ${ }^{288}$ First, the employee-inventor must decide to alienate her interests before she even conceives of the invention and before slie has invested any personality. Second, the employee-inventor lias no ineaningful choice but to accept the terms offered by the employer if she wishes to develop lier personhood by participating

original inventor remains identified on the patent even when the patent is assigned or transferred. In addition, this popular identification of an individual is typically lacking under the team-as-hero paradigm. Today, inventions are identified with firms, not with inventors:

Who invented the dial on your telephone and the machine switching behind it? Who invented the fluid drive or cellophane or Flit or the oil burner or florescent lights or nylon? ...

The best you can say is that General Motors invented this, or that another came out of the Bell Laboratories, but where is the hero?

BURLINGAME, supra note 41 , at 4.

286. See Radin, Market Inalienability, supra note 233, at 1855 ("[W]e may decide that some things should be market-inalienable only to a degree, or only in some aspects.").

287. By "employee inventions," I refer to those inventions that are not controlled by preinvention assignment agreements. This might include inventions conceived and reduced to practice during the employment relationship but before the preinvention assignment agreement became operative. Such inventions are increasingly rare, since most employees must now sign preinvention assignment agreements at the onset of the employment relationship. "Employee inventions" does not refer here to assigned preinventions that mature into inventions-that is, inventions that were conceived and reduced to practice during an employment relationship that was controlled by a preinvention assignment agreement. I refer here to such inventions as "preinventions," since I believe that the conditions under which they come into existencepreassigned to the employer-continue to characterize their nature after conception and reduction to practice.

288. There are reasons for distinguishing preinventions from inventions other than the suspect nature of the decision to alienate. First, the preinvention could be conceived as still within the personality of the inventor while the invention is fully externalized in the patent claims and the embodiment. One is tempted to make comparisons to arguments calling for inalienability of gestational services (that is, payments for surrogate mothers). See, e.g., Radin, MarketInalienability, supra note 233, at 1928-36. However, this comparison fails since the embodimentthe resulting baby-would normally be thought of as even more inalienable than the surrogacy. Second, it might be the inventive process that is personal rather than the invention itself. If so, preinvention assignment agreements can be thought of as commodifying the process by usurping control from the employee-inventor in exchange for her wages. See, e.g., supra note 255 (describing the highly commodified work on an automobile assembly line). 
in the inventive process, given that large firms dominate access to necessary resources and opportunities. ${ }^{289}$ Alienation of other inventions ${ }^{290}$ and preinventions ${ }^{291}$ shares at nost one of these concerns and thus are not as suspect. Given the suspect nature of the decision to alienate preinventions, the reniainder of this Conment will focus on identification of the personhood interests to be protected in the preinvention context and on how this protection inight be impleniented.

\section{B. Non-Personal Inventions: Corporate Inventorship as a Consequence of Personhood Theory}

As discussed above, patent law already recognizes the personhood interests of inventors in two ways: by requiring the identification of the human creators responsible for the invention on the patent application, and by notation of the inventor on the issued patent. This non-transferable, non-assignable, nrarket-inalienable inventorship identification is a form of protection for a personhood interest-the association of the person with her invention.

This limited form of protection is both overbroad and underprotective, however. Inventorship identification is an overbroad form of personhood protection because it creates an irrebuttable presumption of justifiable investment of personhood. While this presuniption is often ac-

289. See Radin, Market-Inalienability, supra note 233, at 1909-10. A prophylactic ban on total alienation of inventors' interests in their future invention is then the "best possible coercionavoidance mechanism under conditions of uncertainty." Id. at 1910.

290. Agreements to assign non-employee inventions not only are non-coercive for the same reasons that non-employee preinventions are, but are also knowingly made, for the inventor can identify precisely what it is that she is assigning.

Assignment of employee inventions are made knowingly for the same reasons that nonemployee assignment of inventions are made knowingly. It is debatable whether employee assignment of inventions is coercive. The employee, of course, is free to end the employment relationship if the employer demands assignment; however, there is a coercive element to such a demand. On the other hand, the employee has the invention which the employer presumably wants, and thus may have some leverage to retain some personhood interest in the invention.

291. Non-employee preinventions are rarely alienated, but presumably could be; that is, an independent inventor could agree with a firm that in return for specified consideration, any inventions coneeived during a specified period would be assigned to the firm. Such "pre-creation" assignment is more familiar in other areas of intellectual property than in the area of inventions. For example, interests in books, films, and records are frequently assigned prior to creation. These types of deals differ from preinvention assignment in numerous respects. First, authors, film-makers, actors, and recording artists usually make such agreements as independent artists rather than as employees. Second, such artists typically retain significant interests in their creations. Third, such artists typically have the leverage to craft individualized agreements and thus the resulting contracts are not adhesive. Fourth, unlike with inventors, the artists' works are strongly identified with the artists.

A "pre-creation" assignment agreement would not be as suspect outside the employment context as it would be within, because the element of adhesion is lacking. This would be the case even if the inventor was under some form of general economic duress. The agreement likely would be crafted individually, and the inventor presumably would be able to negotiate the retention of some interest in the inventions with a prospective assignee. Moreover, in such a case, the personhood of the independent inventor would not have been diminished during the inventive process. 
curate, there are instances where the corporate contribution so exceeds any individual contribution that investment of personhood in the invention or the inventive process is simply not justifiable. Inventorship identification is underprotective of personhood because, in instances where personality is implicated, inventorship identification alone leaves important personhood interests open to appropriation.

The remainder of this Coinment proposes changes in the patent law designed to overcome its current shortcomings in protecting the personhood interests of einployee-inventors. The overinclusiveness objection is addressed by arguing that there are really two classes of einployee preinventions: those witll and those without justifiable personhood interests. This Section will consider preinventions witlout justifiable personhood interests and will advocate recognition of corporate inventorship in those cases. The following Section will look at preinventions tliat do have justifiable personhood interests.

Although inventorship has become increasingly organizational and less independent during the twentietl century, patent law has largely ignored this shift. ${ }^{292}$ Adinittedly, some changes in the Patent Code have inade it easier to obtain patents for team inventions. The Patent Act of 1952, for example, abolished the judicially inposed requireinent that a patentable invention result from a flash of "inventive genius"293 and replaced it witl the current novelty, utility, and non-obviousness standards. ${ }^{294}$ These standards allow the results of inethodical and organized corporate research to be patentable. ${ }^{295}$ Sinilarly, the Patent Law Amendments of $1984^{296}$ provided for an expanded concept of joint inventorship that is more in line with team invention in a corporate environment. ${ }^{297}$ The 1984 amendinents inodified tlie non-obviousness requirement ${ }^{298}$ to reduce the risk that teain inventions would be unpat-

292. See, e.g., Goldstein, supra note 270 , at 359 ("To the chagrin of many observers today, the 1836 Act continues to provide the basic structure and principles of United States patent law.").

293. Cuno Eng'g Corp. v. Automatic Devices Corp., 314 U.S. 84, 91 (1941).

294. 35 U.S.C. $\S \S 101-103$ (1988).

295. See Gamon, supra note 6 , at $499-500$.

296. Pub. L. No. 98-622, 98 Stat. 3383.

297. Section 116 provides in pertinent part:

Inventors may apply for a patent jointly even though (1) they did not physically work together or at the same time, (2) each did not make the same type or amount of contribution, or (3) each did not make a contribution to the subject matter of every claim of the patent.

35 U.S.C. $\$ 116$ (1988). The legislative history of the amendment "recognizes the realities of modern team research. A research project may include many inventions. Some inventions may have contributions made by individuals who are not involved in other, related inventions." 1984 U.S.C.C.A.N. 5827, 5834.

298. The amendment added the last sentence to 35 U.S.C. $\$ 103$ (1988):

Subject matter developed by another person, which qualifies as prior art only under subsection ( $f$ ) or $(\mathrm{g})$ of section 102 of this title, shall not preclude patentability under this section where the subject matter and the claimed invention were, at the time the invention 
entable due to the prior research efforts of team members. ${ }^{299}$

These statutory changes and the gradual acknowledgment of team invention in the case law, ${ }^{300}$ however, have been of only limited effect. At its core, patent law still clings to the concept of the "hero-inventor" and rejects the modern paradigm of "team-as-hero." Despite the deficiencies of the "team-as-hero" paradigm, the recognition of corporate inventorship would be a significant step toward modernizing patent law to reflect contemporary inventorship paradigms. ${ }^{301}$

Corporate inventorship need not be a particularly radical step for patent law. ${ }^{302}$ First, recogmition of corporate inventorship would merely parallel developments in other areas of American intellectual property law, such as copyright ${ }^{303}$ and mask work protection, ${ }^{304}$ where "author-

was made, owned by the same person or subject to an obligation of assignment to the same person.

Pub. L. No. 98-622, § 103, 98 Stat. 3383, 3384 (1984).

299. See DRATLER, supra note $25, \S 2.04[3]$, at 2-103 to 2-104 (discussing the purpose of the 1984 amendments).

300. See Gamon, supra note 6, at 502-10 and cases cited therein (discussing case developments in patent law).

301. It is inportant to note that corporate patents have becn advocated before. See, e.g., id. at 512-13.

302. The wisdom of a corporate patent has been debated in the hiterature. See Sears, supra note 89 (arguing against corporate patents, largely on constitutional grounds); Gamon, supra note 6, at 512-13, 519-21 (advocating corporate patents). Sears' usage of the term "corporate patents" differs from that advocated here. She refers to a series of proposed reforms favoring team invention. Since Sears' article was written, some of the proposed reforms have been enacted. See supra notes 296-98 and accompanying text.

303. The 1976 Copyright Act rccognizes an economic basis of authorship that defines an author as the entity that finances the creation of the work. This basis is embodied in the Copyright Act as the "work made for hire" doctrine. According to the Act,

A "work made for hire" is -

(1) a work prepared by an employee within the scope of his or her employment; or

(2) a work specially ordered or comnissioned for use as a contribution to a collective work ... if the parties expressly agree in a written instrument signed by them that the work shall be considered a work made for hire.

17 U.S.C. $\$ 101$ (1988). The Act proceeds to state that

[i]n the case of a work inade for hire, the employer or other person for whoin the work was prepared is considered the author for the purposes of his title, and, unless the parties have expressly agreed otherwise in a written instrument signed by them, owns all of the rights coinprised in a copyright.

Id. $\S 201$ (b). Thus, copyright law recognizes by statute that corporations may be considered the authors of the works they finance. However, the scope of copyright protection is not precisely the same in all respects as for human authors. For example, due to the theoretically infinite corporate lifetime, copyright protection for works made for hire "endures for a term of seventy-five years from the year of its first publication, or a term of one hundred years froin the year of its creation, whichever expires first," as opposed to the "life of the author and fifty years" duration of protection for works of human authorship. Id. $\$ 302(\mathrm{a})$, (c).

304. The Semiconductor Chip Proteetion Act of 1984 (SCPA), id. $\$ 901-914$, is a sui generis form of intellectual property protection for mask works fixed in semiconductor chip products. Under the SCPA, mask works created by employed designers are the property of the employer:

[T] he "owner" of a mask work is the person who created the inask work, the legal representative of that person if that person is deceased or under a legal incapacity, or a party to whom all rights under this chapter of such person or representative are transferred in accordance with section 903(b); except that, in the ease of a work made within the scope 
ship" can be based on economic grounds as well as on the more traditional creation grounds. Furthermore, most foreign countries already recognize corporate imventors. ${ }^{305}$

Second, the availability of corporate imventorship would not harm employee-imventors, since nearly all employee-inventors are already required to assign their patent rights to their employer. In fact, the availability of corporate inventorship could significantly help employeeinventors. Courts generally enforce questionable preinvention assignment agreements as a matter of policy. If corporate inventorship were available and a corporation did not qualify for inventor status, courts might be less hikely to enforce adhesive contracts purporting to assign a patent to the corporation. ${ }^{306}$

The question remains, however, as to when a corporation should qualify as an inventor. One model is provided by the "work for hire" doctrime of section 101 of the Copyright Act of 1976. ${ }^{307}$ Section 101 defines two classes of works inade for hire: works prepared by employeeinventors within the scope of their employment, and works specially ordered or commissioned for use as a contribution to a collective work. Another potential model, prescribed by the state statutes discussed earher in Section II.D, would describe those employee-inventions that are not eligible for corporate inventorship. Thus, under a inodel suggested by the Califorma statute, corporate inventions would be limited to those invented by employee-inventors during corporation time, or using corporation resources, or relating to present or anticipated areas of corporate business or research or development. ${ }^{308}$

These models would probably provide too broad a scope for corporate inventorship, however, for both definitions of inventors would include virtually all einployee inventions conceived at work. Many of these inventions would represent windfalls to the corporate employer if insignificant corporate resources had been expended and the corporation had not directed the activity leading to the invention. In other words, an invention that owes more to the initiative of the employee-inventor than to the resources and direction of the corporate employer should not qualify as a corporate invention. A better definition of corporate inventions would combine aspects of both of the models by limiting a corporate invention to an anticipated result of corporate direction ${ }^{309}$ that was conceived

of a person's employment, the owner is the employer for whom the person created the mask work or a party to whom all the rights under this chapter of the employer are transferred in accordance with section 903(b).

Id. $\S 901(\mathrm{a})(6)$.

305. See Gamon, supra note 6, at 522-23.

306. Though, admittedly, courts appear unlikely to do this sua sponte, without legislative prodding.

307. 17 U.S.C. $\S 101$ (1988). This section is reproduced in pertinent part supra note 303.

308. See CAL. LAB. Code $\S 2870$ (West 1992).

309. By "anticipated result of corporate direction," I refer to specific management supervision 
and reduced to practice using significant corporate resources. All other patent applications would still require named human inventors.

This model of corporate inventorship should include a rebuttable presumption of individual inventorship by natural persons. If, for example, a corporation files a patent apphication claiming corporate inventorship, and one or more employee-inventors feel that the invention resulted primarily from their personal efforts, they could file an interference action with the Patent Office to determine inventorship. ${ }^{310}$

If corporate inventorship were the only patent law modification made, however, hittle change would be reflected in the actual allocation of patent rights. Corporations would, of course, hold title to those patents for which the corporation was given inventorship credit, and through preinvention assignment agreements, corporations would obtain title to their employee-inventors' patents. What is needed to supplement this modification is a means to deal with bona fide personal inventions of employee-inventors.

\section{Personal Preinventions: The Employee-Inventor and the Personhood Defense}

Thus far, this Comment has argued that employee premventions are a form of partially noncommodifiable property. How should this idea affect the allocation of rights between employee-inventors and employers in inventions with justifiable personhood interests? This Section explores three possible methods of applying personhood theory to employee preinventions.

First, the law could recognize the justifiable personhood interests of employee-mventors in their preinventions and make these interests inalienable. This will be referred to as a "non-appropriability approach."

Second, the law could recognize corporate proprietary interests in the preinventions of employee-inventors analogous to huinan personhood interests. The corporate interest could either cancel the employee-inven-

of the inventive process. For example, if a manager (or any corporate agent) tells an engineer that a component is needed with specified characteristics and the engineer proceeds to develop such a component, and that component turns out to be a patentable device or employs a patentable process, and the engineer would qualify as an "inventor" under the present Patent Code, then I would designate such an invention a corporate invention. On the other hand, if while fulfilling the manager's request, the engineer conceives of an idea for an unrelated or peripherally related patentable invention, the invention would not be the anticipated result of corporate direction and would not qualify as a corporate invention. Note that "anticipated" as used here would not present a bar to patentability under the novelty or non-obviousness requirements of 35 U.S.C. $\S \S 102-103$ (1988).

310. See id. $\S 135$ (section authorizing interference actions). Interferences are ordinarily initiated to determine priority of invention, see id., but could be used or easily adapted to determine questions of corporate versus individual inventorship. The presumption of individual inventorship would be analogous to the current rebuttable presumption that the chronological order of filing dates is the order of actual invention. See 37 C.F.R. $\$ 1.657$ (1991). 
tor's personhood interest in the saine property-thus making the property ahenable-or be balanced against the interests of the employeeinventor on a case-by-case basis. This will be referred to as a "cancelling or balancing approach."

Fimally, the law could reject corporate "personhood" interests and disaggregate the rights incidental to employee preinventions. Those interests that are justifiably constitutive of the personality of the employeeinventor could be identified and made market-inalienable. All other rights incidental to employee preinventions would then be freely alienable. This will be referred to as a "disaggregation approach."

\section{A Non-Appropriability Approach}

The non-appropriability approach suggests that employee preinventions should be non-assignable because they embody the personality of their inventor. Inventions, however, have both personal and non-personal attributes. A regime of complete malienability of invention rights would be overprotective of personhood, since it would remove non-personhood interests from the market. Non-appropriability can be overinclusive, as well, if non-personal inventions are protected. Thus, a regime of total malienability is difficult to imagine, let alone advocate, absent corporate inventorship for a significant percentage of the inventions of the employee-inventor.

Under a regime of total inahenability, employee preinventions could only be exploited by their original, human inventor, unless the employers obtained rights to the inventions via costly ex post negotiations. Such a regime would be far worse for corporations than a regime with no intellectual property protection at all, since corporations could be forbidden from exploiting the output of their own laboratories. Investment in organized research and development would likely be curtailed significantly. This negative consequence could be amehorated, however, by permitting the gift-giving or sharing of the noncommodifiable property. ${ }^{311}$ Thus, it might be possible under an inahienability regime for a group of researchers to work together, placing all patents received by any member into a common pool. ${ }^{312}$ Such an approach, of course, would be more a cooperative arrangement than an employer-employee relationship. Moreover, if an invention were particularly valuable, the inventor would presumably be free of compulsion to place it in the pool, for such compulsion would alienate her personality. For this reason, the system would be unlikely to work in a corporate environment.

Another variation on the inalienability regime would be to make

311. See Radin, Market-Inalienability, supra note 233, at 1854-55 (noting that inalienability can co-exist with encouragement of gift-giving).

312. Patent pools are a means of linking the rights to use the patents issued to more than one patentee. See, e.g., United States v. Line Material Co., 333 U.S. 287, 313 n.24 (1948). 
employee inventions inalienable but to grant employers non-transferable, non-exclusive slop-riglits ${ }^{313}$ to exploit the employee-inventor's preinvention. This would to some extent represent a return to the common law allocation sclieme; lowever, the restrictions on alienability would preclude, at least for employee imventions, the patent licensing and transfer agreements that allow inventions to realize their optimal utility. Many firms inight reduce expenditures on innovation under such a scheme.

Thus, it would seem that a regime of complete inalienability is not a desirable solution to the problem of the employee-mventor, even where schemes of gift-giving, corporate inventorship, and employer shop-riglits are available to soften its impact. This conclusion, lowever, does not totally devalue the contribution personhood theory can make to solving the preinvention problem, if approaches can be developed that protect personliood interests witlout imposing complete inalienability.

\section{A Cancelling or Balancing Approach}

One alternative to the non-appropriability approach is a cancelling or balancing approach. This approach requires recognition that the corporation may have a justifiable personhood (or, analogously, proprietary) interest in the preinventions of employee-inventors. This interest would then eitlier cancel the employee-inventor's personhood interest or be balanced against it. ${ }^{314}$ A cancelling or balancing approacl would juxtapose the individual personhood interests against corporate interests of a similar nature, and either the corporate interest could cancel the individual interest $^{315}$ or the two interests could someliow be balanced against eacli other. $^{316}$

Unfortunately, a cancelling or balancing approach that compares the personhood interests of liumans and corporations has serious flaws. The assignment of a personhood interest to a corporate entity is incongruous witl Professor Radin's conception of personhood, notwitlistanding the status of legal personhood enjoyed by corporations. ${ }^{317}$ Corporate personhood is generally acknowledged to be a mere legal fiction, utilized for reasons of economic efficiency ${ }^{318}$ or convenient terminology. ${ }^{319}$ Per-

313. See supra note 96 and accompanying text for a discussion of common law shop-rights.

314. Professor Radin uses the example of certain noncommercial claims of landlords, such as those of landlords who live on the premises, that can offset or defeat a tenant's personhood interest in continuing to live in an apartment that she has made her home. See Radin, Residential Rent Control, supra note 233, at 359-60.

315. In this case some other interest would have to be asserted by either the individual, the corporation, or both in order to justify the awarding of the property right.

316. In this case the entity offering the more compelling interest would prevail.

317. See Robert C. Clark, Corporate Law 675-76 (1986) (discussing the "meaning of corporate personality").

318. See id. at 15-21 (discussing the economic efficiency of legal personhood).

319. See LoN L. Fuller, Legal Fictions 12-14 (1967) (discussing the possibility that legal personhood is merely a convenient metaphor). Furthermore, Professor Dan-Cohen argues that 
sonhood theories of property seek to protect the moral status or dignity of personhood, ${ }^{320}$ rather than mere legal status. Legal corporate personhood is thus insufficient to bring corporate property into a regime of market-malienability.

As noted earlier, ${ }^{321}$ one indicium of a personhood interest in property is that its owner places a greater-than-market value on the property. While this is often a rehable indicium when applied to natural persons, it is entirely unreliable when applied to corporations. Corporate willingness to pay more than market value is simply an indication that the corporation is able to realize greater than market returns from the property. Such willingness is not a ineasure of the corporation's personhood or proprietary interest in the property, but rather an indication that market pricing may be flawed by such factors as imperfect infornnation.

In the kingdom of corporate ends, everything has a price and nothing lias a dignity. ${ }^{322}$ Unlike some personhood interests of natural persons, it is difficult to come up with any examples of interests that are inahenable to corporations. ${ }^{323}$ A person cannot sell her body parts, but a corporation can sell its divisions, or even the entire corporation. Corporations can even sell what might be argued is analogous to personalitythe corporate "good will"- though in practice this might require the sale of the entire corporation. In the end, the concept of protecting the inalienable or noncommodifiable interests of firns is not supportable. Thus, the cancelling or balancing approach is unsatisfactory as a ineans of allocating rights im employee inventions.

\section{A Disaggregation Approach \\ a. The Fungible/Personal Dichotomy}

If corporations cannot have protectable personhood interests in property, can personhood theory provide a means of resolving preinvention disputes? I believe that it can-precisely because it distinguishes

corporations are merely "intelligent machines" that cannot enjoy the moral status and privileges of human persons. DAN-COHEN, supra note 55, at 49-51. For discussions on the personhood of another type of "intelligent machine," see Pamela Samuelson, Allocating Ownership Rights in Computer-Generated Works, 47 U. PITT. L. REv. 1185, 1199-200 (1986) (arguing computers should not be treated as the authors of computer-generated code). See generally Lawrenee B. Solum, Legal Personhood for Artificial Intelligences, 70 N.C. L. REv. 1231 (1992) (discussing the issues surrounding the possible treatment of an artificial intelligence as a legal person).

320. See DAN-CoHEN, supra note 55, at 96.

321. See supra text accompanying note 239.

322. See supra note 217.

323. Courts sometimes confuse the legal fiction of the corporate person with personhood in the Hegelian sense. For example, early ecclesiastical courts sometimes punished corporate misbehavior with excommunication; the practice was banned by Pope Innocent IV in the 13th century on the grounds that a corporation, having no soul, could not lose one. See John C. Coffee, Jr., "No Soul to Damn: No Body to Kick": An Unscandalized Inquiry into the Problem of Corporate Punishment, 79 Mich. L. REv. 386, 386 n.2 (1981). 
between corporations and individuals. The traditional property theories, discussed in Section III.B., failed to resolve preinvention assignment disputes because they could not distinguish between the employee-inventor and employer. The first approach discussed in this Section, the non-appropriability approach and its several variations, distinguishes einployeeinventor froin employer but seems to protect too much. The cancelling or balancing approach, like traditional property models, fails because it equates corporate and individual interests and does so imperfectly. The solution proposed here is to disaggregate the rights attaching to an invention, identifying and protecting those rights that have the most important personality consequences, while treating the others as ahenable.

Disaggregation is a familiar-if not essential-concept in any scheme of intellectual property. In copyright, for example, books are conceptually disaggregated into the physical thing and the idea. The buyer gets the physical object when she purchases the book, but the author keeps the form of expression which embodies her personality. This aspect of the work-the author's expressiou-is protected by copyright. ${ }^{324}$ The idea/expression dichotomy is codified in the Copyright Code. $^{325}$ Similar idea/embodiment and idea/layout dichotomies are familiar to patent law ${ }^{326}$ and mask work protection, ${ }^{327}$ respectively.

The key to allocating riglits in employee preinventions under a personhood theory, then, is tle establishment of a "fungible/personal" dichotoiny. ${ }^{328}$ This is both consistent witl personhood theory, whicl1 accommodates partially commodifiable goods, ${ }^{329}$ and witl intellectual property theory, which accommodates disaggregation of property rights in things. In fact, patent law already recognizes a fungible/personal dichotomy: credit for inventorship is seen as personal and therefore inalienable, while all otlier rights attaching to inventions are seen as fungible and therefore ahenable.

Why aren't rights otlier tlian inventorship credit treated as per-

324. See, e.g., Boyle, supra note 265 , at 1466.

325. 17 U.S.C. $\$ 102(b)$ (1988) provides as follows: "In no case does copyright protection for an original work of authorship extend to any idea, procedure, process, system, method of operation, concept, principle, or discovery, regardless of the form in which it is described, explained, illustrated, or embodied in such work." For a general discussion of the idea/expression dichotomy, see DRATLER, supra note $25, \S 5.01$ [2]. For the common law origin of the doctrine, see Baker v. Selden, 101 U.S. 99 (1880).

326. The scientific principles and mathematical formulas and algorithms that underlie an invention are not patentable, even if newly "discovered" by the inventor. See generally DRATLER, supra note $25, \S 2.02[2]$ ("These things may be discovered by man, but they are not made by man.").

327. 17 U.S.C. $\$ 902(c)$ (1988) provides as follows: "In no case does protection under this chapter for a mask work extend to any idea, procedure, process, system, method of operation, concept, principle, or discovery, regardless of the form in which it is described, explained, illustrated, or embodied in such work." For a general discussion of the idea/layout dichotomy, see DRATLER, supra note $25, \S 8.03[4]$.

328. See Radin, Property and Personhood, supra note 233, at 986-88 \& n.102, 1005-06.

329. See supra notes $246-47$ and accompanying text. 
sonal? One possibility is that the rights are viewed from an external rather than internal perspective. At times, society identifies an inventor with her creation. Thus, creative credit is nonconmodifiable. But as was stressed previously, ${ }^{330}$ it is how the inventor identifies herself that is more significant. ${ }^{331}$ For an inventor, this self-identification is done largely through the inventive process-through her work with the invention.

\section{b. The Personhood or Inventor's Defense}

Professor Radin's treatment of work provides guidance as to which of the inventor's interests should be protected: those that contribute to the inventor's self-conception in ways inseparable froin the inventive process, those that contribute to her continuity in the inventive process, and those that contribute to her control over the inventive process. ${ }^{332}$ Each of these interests can be protected by granting the inventor continued access to her invention independent of her employment relationship with the assignee. "Access" is used here in a fairly broad sense: the continuing ability to make use of the mvention.

If an employee created an invention during the course of employment that was patented in the employee's name and assigned to the einployer under a preinvention assigninent agreement, the inventor could enjoy continuing access to the invention through the availability of an affirmative "personhood" or "inventor's" defense to patent infringement actions. The defense would be personal to the inventor and would protect only uses that were justifiably bound up with personhood. The personhood defense would have the effect of granting inventors a personal "reverse shop-right" in their inventions. ${ }^{333}$ This reverse shop-right would permit employee-inventors to inake, use, and sell their invention outside the employment relationship. This right would be inalienable. Thus, if an employee-imventor found that her employment relationship was not constitutive of personality vis-à-vis her invention, she would be free to leave the employer while continuing to exploit the invention on her own.

330. See supra notes 284-85 and accompanying text.

331. Again, a purely subjective approach is not suggested here. Reliable indicia of reasonable, justifiable personhood interests must be present for the personhood interest to be protected.

332. See supra notes $256-59$ and accompanying text.

333. The reverse shop-right has been proposed before, but as an instrumental tool rather than a normative protection of personal interests. See Hovell, supra note 6, at 887-88. At least one court has refused to award an employee a reverse shop-right in an employer-owned invention. See Mainland Indus., Inc. v. Timberland Mach. and Eng'g Corp., 649 P.2d 613 (Or. Ct. App.), review denied, 653 P.2d 999 (Or. 1982), cert. denied, 460 U.S. 1051 (1983). The Mainland court reasoned that while equity favored awarding employers a shop-right in employee-owned inventions, there were no such arguments in favor of the employee, as the employer rather than the employee had made the investment. This view has been disputed throughout this Comment, see, e.g., supra notes 72-80 and accompanying text, and elsewhere, see, e.g., Dratler, supra note 6, at 132-33. For commentary supporting the Mainland reasoning, see Mislow, supra note 6, at 76-77. 
The employer, for its part, would also be free to exploit the imvention. Furthermore, the employer would be free to treat its interest $m$ the invention as fungible-that is, it could assign, transfer, or hicense the $\mathrm{m}$ vention to another-while the employee-mventor could not. Thus, the employer would not "lose" its investment in research under this proposal. Rather, the employer would get nearly the same rights as under current preinvention assignment agreement schemes, the only distinction being that the formerly exclusive rights would now not exclude the inventor herself.

Two additional elements would be needed to support the personhood defense. First, there must be some means of protectimg ex-employee-imventors from the threat of vexatious hitigation on the part of employers. By their very nature, personhood defense cases will tend to pit individuals and small entrepreneurial corporations against large es. tablished corporations. The threat of costly hitigation would deter many individuals and small corporations, even those confident that their use was protected, from exploiting personal inventions. A rebuttable presumption of personal use, combined with a reduced threshold for imposing sanctions for frivolous or vexatious litigation on the part of employers, may help to reduce these potential problems. ${ }^{334}$

Second, employers might try to contract around the personhood defense by requiring technical employees to sign long-term employment contracts or by utilizing noncompetition clauses im employment contracts. The personhood defense should be applied to breach-of-contract actions that atteinpt to prevent employee-inventors from using their inventions in ways that are constitutive of personhood, or that attempt to recover employee-inventor profits or employer losses from such uses.

\section{c. Some Applications of the Personhood Defense and Comparisons to Current Doctrines}

There are, of course, many uses for inventions. These cover the spectrum from the fully commodified to the fully personal. In order to be sufficiently protective of personhood, the defense would apply to those uses that contained a significant element of personahty. The following examples indicate some of the activities to which the defense might apply. Each is compared with a current patent doctrine that does not adequately protect the personhood interests of inventors.

\section{i. Private Personal Use}

An inventor's private personal use of her invention for experimental purposes would be a protected use under the scheme outlined above.

334. The sanctions might have to be quite large and be imposed on the parties as well as their attorneys, since corporations could otherwise find it very profitable to squelch potential competitors through expensive litigation. 
Such a use clearly contributes to the inventor's continuity and control over the inventive process and thus is constitutive of personhood. Thus, for example, the inventor would be free to use the invention for the purposes of developing a new invention. The inventor would be free to inake any commercial use of the new invention and be immune to infringennent charges for her commercially inotivated use of the assigned invention. The use of the assigned invention can be deemed personal because it contributed to the continuity of the inventive process.

\section{ii. As Compared to the Experimental Use Doctrine}

Current patent law provides for an experimental use defense to infringement actions. ${ }^{335}$ This judicially created defense is not limited to inventors and is unavailable if the experimental use is related to business or commercial purposes. ${ }^{336}$ The experimental use defense is an overbroad forn of personhood protection because even non-inventors may invoke it. ${ }^{337} \mathrm{It}$ is underprotective of personhood interests because it does not protect commercial uses that inay be constitutive of an inventor's personhood. The personhood defense would expand the experimental use doctrine to allow any experimental use of the invention by the forner employee-inventor, even if commercially motivated.

\section{iii. Personal or Professional Commercial Exploitation}

Even the inventor's direct commercial exploitation of the invention could be sufficiently personal to be immune from infringement under the personhood defense. ${ }^{338}$ A direct commercial exploitation would be sufficiently personal if it were justifiably constitutive of the inventor's personhood, either personally or professionally. An example of a protected personal use would be the creation of a new invention dependent upon the original invention. An example of a protected professional use would be the commercial development of the invention. Thus, if the inventor were to found and manage a company for the purpose of exploiting the invention, this activity might be immune froin charges of infringement. The founding of a company based upon one's inventive product can be justifiably constitutive of personhood. ${ }^{339}$ However, not every profes-

335. See Roche Prods. v. Bolar Pharmaceutical Co., 733 F.21 858, 863 (Fed. Cir.), cert. denied, 469 U.S. 856 (1984). This defense is narrowly construed and limited to philosophical inquiry, satisfaction of curiosity, or amusement. Id.

336. Id.

337. Of course, there may be valid policy rationales for extending experimental use protection to non-inventors.

338. See, e.g., Radin, Property and Personhood, supra note 233, at 987 ("Perhaps the entrepreneur factory owner has ownership of a particular factory and its machines bound up with her being to some degree.").

339. One commentator has discussed how such firms can be constitutive of personhood, even though commercial in nature, and why, in fact, the personhood interests contribute to their commercial success: 
sional involvement with the invention would be protected. For example, the inere subsequent employment of an inventor by soineone other than the patentee would not ordinarily immunize the subsequent einployer from hability for infringement.

\section{iv. As Compared to the Assignor Estoppel Doctrine}

The protection of personal or professional commercial exploitation as described above would help the courts resolve the particularly difficult problems they have had over the years with the doctrine of assignor estoppel. The judicially created doctrine of assignor estoppel precludes patent assignors, typically employee-inventors, froin contesting the vahidity of patents that they have assigned, typically in infringement actions brought by their forner employers. ${ }^{340}$ Assignor estoppel has proved particularly problematic for the courts ${ }^{341}$ because it represents a clash between the principles of contract and patent law. Justice Harlan expressed this conflict as follows:

On the one hand, the law of contracts forbids a purchaser to repudiate his promises simply because he later becomes dissatisfied with the bargain he has inade. On the other hand, federal law requires that all ideas in general circulation be dedicated to the common good unless they are protected by a valid patent. ${ }^{342}$

Inventor-entrepreneurs can foresee tangible personal rewards if they are successful. Individuals often want to achieve a technical contribution, recognition, power, or sheer independence, as much as money. For the original, driven personalities who create significant innovations, few other paths offer such clear opportunities to fulfill all their eeonomic, psychological, and career goals at once. Consequently, they do not panic or quit when others with solely monetary goals might.

James B. Quinn, Managing Innovation: Controlled Chaos, HARv. Bus. REv., May-June 1985, at 73.

340. See generally Ubell, supra note 117; Hatfield, supra note 174.

341. Judicial support of the doctrine has waxed and waned over the years. Assignor estoppel and the related doctrine of licensee estoppel were established in American patent jurisprudence in the mid-19th century. See Kinsman v. Parkhurst, 59 U.S. (18 How.) 289 (1855); see also Lear v. Adkins, 395 U.S. 653, 663-64 (1969) (discussing early applications of licensee estoppel); Rochelle C. Dreyfuss, Dethroning Lear: Licensee Estoppel and the Incentive to Innovate, 72 VA. L. REv. 677, 684-85 (1986) (same); Hatfield, supra note 174, at 260 (discussing early applications of assignor estoppel). The doctrine was still alive in the mid-20th century, see Scott Paper Co. v. Marcalus Co., 326 U.S. 249 (1945), though by that time numerous exceptions had nearly swallowed the rule. See, e.g., Lear, 395 U.S. at 664-68 (discussing exceptions to rule); Hatfield, supra note 174, at 264-67 (same). The Court in Scott Paper, for example, declined to estop the defendant from claiming that the patent he had allegedly infringed was invalid as it was anticipated by prior art. Scott Paper, 326 U.S. at 257. The decision was not uncontroversial, however. Justice Frankfurter wrote a vigorous dissent, noting that assingor estoppel "has been part of the fabric of our law throughout the life of this nation. It has been undeviatingly enforced by English speaking courts in this country, in England, in Canada, and Australia." Id. at 260 (Frankfurter, J., dissenting). Assignor estoppel was generally thought to have been abolished soon thereafter in Lear, 395 U.S. at 653 (abolishing licensee estoppel and criticizing "patent estoppel" generally), but was resurrected by the Federal Circuit in two recent cases: Diamond Scientific C. v. Ambico, Inc., 848 F.2d 1220 (Fed. Cir.), cert. dismissed, 487 U.S. 1265 (1988) and Shamrock Technologies v. Medical Sterlization, 903 F.2d 789 (Fed. Cir. 1990).

342. Lear, 395 U.S. at 668. 
Proponents of assignor estoppel feel that the doctrine is necessary to protect employers' investinent in research and development. ${ }^{343}$ Opponents counter that the realities inherent in the bargaining process and the patent application procedure behe the assumption, implicit in the doctrine, that the employee-inventor has previously attested to the validity of the patent. ${ }^{344}$

The debate over the question of assignor estoppel has been so heated because the stakes are so high and the options so poor. The employeeinventor has no good alternatives, particularly when her personhood interests are considered. Under assignor estoppel, she cannot develop her freedoin, identity, and contextuality through continued access to her invention. Even if assignor estoppel is held inapplicable, she must either relinquish access (and thus, developinent of personhood) or diıminish her personhood by asserting that her invention was not patentable. If the employee-inventor chooses the latter route and prevails, the invention enters the public domain and anyone, not just employer and employeeinventor, may practice it. In this case the employer indeed has little to show for its research and developinent investment.

Courts are asking the wrong questions in these cases. Rather than inquiring whether employee-inventors ought to be allowed to attack the patentability of their inventions, courts should consider whether employee-inventors can be divested of all interests in an invention through a preinvention assignment agreement. The personhood defense answers this question through a careful exammation of the employee-inventor's relationship to the invention, rather than divorcing the invention from the creator by precluding the employee-inventor from even addressing the work's patentability. The personhood defense approach is preferable to the assignor estoppel approach because it is constitutive rather than destructive of an employee-inventor's personality. ${ }^{345}$

$\mathrm{V}$

\section{CONCLUSION}

This Comment has attempted to resolve a problem recognized for years but resistant to reform efforts: the allocation of rights to future

343. See, e.g., Hatfield, supra note 174, at 273.

344. See, e.g., Ubell, supra note 117, at 27-30. Ubell emphasizes that the employee-inventor is in no position to vouch for the patentability of any inventions she assigns to her employer-this is a question of law to be determined by the employer's patent attorney. Thus, the employee-inventor's oath and signature ought not to preclude her from later asserting that the patent is invalid. Id.

345. Furthermore, even employers are arguably better off under the personhood defense. The assignor estoppel doctrine is subject to numerous exceptions. See supra note 341. If an exception applies to the facts of a particular case, the employer's patent may be found invalid. The employer has less to lose under the personhood defense approach. Even in those cases where the defense is operative, employer-patentees retain the right to exclude all but the employee-inventor from making, using, and selling the invention in question. 
inventions between employee-inventors and their corporate employers. It suggests the basis for a workable solution to this age-old problem: to treat the justifiable personhood interests of employee-inventors as market-inalienable and to make all other interests fully commodifiable. This proposed framework focuses on the nature of the property in dispute rather than on the relationship between the parties. It is based on a "hybrid" conception of invention that recognizes the contributions of both individuals and firms, rather than only the "hero-inventor" or "team-ashero." It thus provides a more flexible means of protecting the interests of both employee-inventors and their corporate employers.

The proposed personhood approach has two primary policy implications. First, it recognizes the contributions of corporate employers where appropriate by allowing corporations to claim inventorship under the Patent Code when an imvention is the anticipated result of corporate direction. Second, this approach protects the justifiable personahity interests of employee-inventors in their inventions by providing a personhood defense to infringement actions. These two recommendations are complementary: some employee-inventors will reap increased rights in their imventions, but many inventions will remain in the corporate name, beyond exploitation by employee-inventors.

The personhood approach suggested here is consistent with the distinctive nature of intellectual property discussed earher. Intellectual property has both "free good" and "public good" attributes. ${ }^{346}$ The "free good" attribute allows the employee-inventor and employer to exploit the invention simultaneously without depriving either party of its use or enjoyment; the "public good" attribute necessitates that the personhood defense be personal to the inventor and non-transferable. This circumscribed exception to the employer-inventor's exclusive patent rights will continue to exclude free-riders who do not contribute significantly to the production of the invention.

Intellectual property rights are also of limited scope and duration. ${ }^{347}$ They protect only certain of the "bundle of riglits" associated with tangible property. Consequently, the disaggregation of interests in inventions and the reduction in the scope of the employer's right to exclude personal and commercial uses by the employee-inventor do not undercut the integrity of the imtellectual property protection.

Finally, intellectual property has traditionally been thought of as a "democratic" form of property. ${ }^{348}$ The retention of residual rights by individual employee-inventors will tend to be wealtl1-redistributive. It will cause some-tlougl, in all likelihood, relatively little-slift of

346. See supra note 147 and accompanying text.

347. See supra note 148 and accompanying text.

348. See supra note 149 and accompanying text. 
wealth from corporations to individuals. It will to some extent empower individual employee-inventors to compete against large corporations.

The personhood approach supplements the traditional theoretical property justifications discussed earlier in Section III.B. Under traditional theories, both employee-inventors and employers can articulate persuasive arguments for intellectual property protection. These theories cannot, however, adequately distinguish between the claims of employeeinventors and employers, and personhood theory provides a useful tool for allocating rights in a reasoned, justifiable manner.

Ultimately, of course, employee-inventors are perfectly capable of acting to protect their personhood interests themselves, either by becoming independent inventors or by becoining non-inventors. They may move to other fields of work where their personhood interests are less likely to be appropriated by firms or where individual activity is more practicable. $^{349}$ However, their departure can turn into a serious resource allocation problem for society. In a perverse way, then, current patent and contract doctrine may be reducing rather than enhancing social welfare.

Because the control of ideas confers substantial benefits on inventors, intellectual property structures are likely to arise in any social system containing self-interested actors. Even without goverumental assistance, individual innovators will do their utinost to create a regime that rewards creativity; the only question is whether the results will be better or worse than the governmental alteruative. ${ }^{350}$

Although this Coinment has emphasized normative rather than instruinental concerns, the norinative probleins with preinvention assignments do not exist in an instruinental vacuum. Ainerica's declining productivity growth, ${ }^{351}$ rate of innovation, ${ }^{352}$ and supply of engineers and scientists ${ }^{353}$ have been the cause of great concern in recent years. ${ }^{354}$

349. Law, for example.

350. Mark C. Suchman, Invention and Ritual: Notes on the Interrelation of Magic and Intellectual Property in Preliterate Societies, 89 Colum. L. REv. 1264, 1290-91 (1989).

351. See Steven Greenhouse, Attention Americal Snap out of Itl, N.Y. T1MES, Feb. 9, 1992, $\$$, at 1 (detailing America's lack of productivity growth relative to that of Japan and Germany).

352. See, e.g., Hatfield, supra note 174, at 251-55.

353. See, e.g., William R. Greer, Foreign Students: Boon or a Threat?, N.Y. TIMEs, Mar. 27, 1983, $\S 12$, at 72; Barbara Vobejda, Foreign Students Proliferate in Graduate Science Programs: Shortage of American Expertise Foreseen, WASH. Post, Sept. 2, 1987, at A1; Amy S. Wells, More Foreigners Are Seeking Ph.D.'s in U.S., N.Y. TIMES, July 20, 1988, at B6.

354. The rate of private investment in research and development has also been of increasing concern. See, e.g., Stuart Auerbach, U.S. Firms Lag Japanese in Spending: Study Fuels Debate on Competitiveness, WaSh. Post, June 29, 1990, at G2; William J. Broad, Japan Seen Passing U.S. in Research by Industry, N.Y. TimEs, Feb. 25, 1992, at B5. If, as has been discussed earlier, see supra note 201 and accompanying text, the efficacy of patent law generally in stimulating investment is debatable, then the effect of the retention of a non-exclusive, non-transferable right of an inventor to exploit her own invention would be minuscule. As has been noted in another context, "acceptance 
Perhaps the alienation (in every sense) of the American technologist is, in some part, to blame.

of a patent system by uo means compels the conclusion that any subtraction from the bundle of patentee's rights is necessarily bad public policy." Donald F. Turner, The Patent System and Competitive Policy, 44 N.Y.U. L. REv. 450, 458 (1969) (arguing for antitrust limitations on a patentee's licensing rights). 
